Sheila Fernandes Pimenta e Oliveira

Vânia de Fátima Martino

Genaro Alvarenga Fonseca

Ana Lúcia Furquim Campos Toscano (org.)

\title{
Formação Docente: um processo em contínua construção de conhecimento
}

Coleção Educação e Educandos
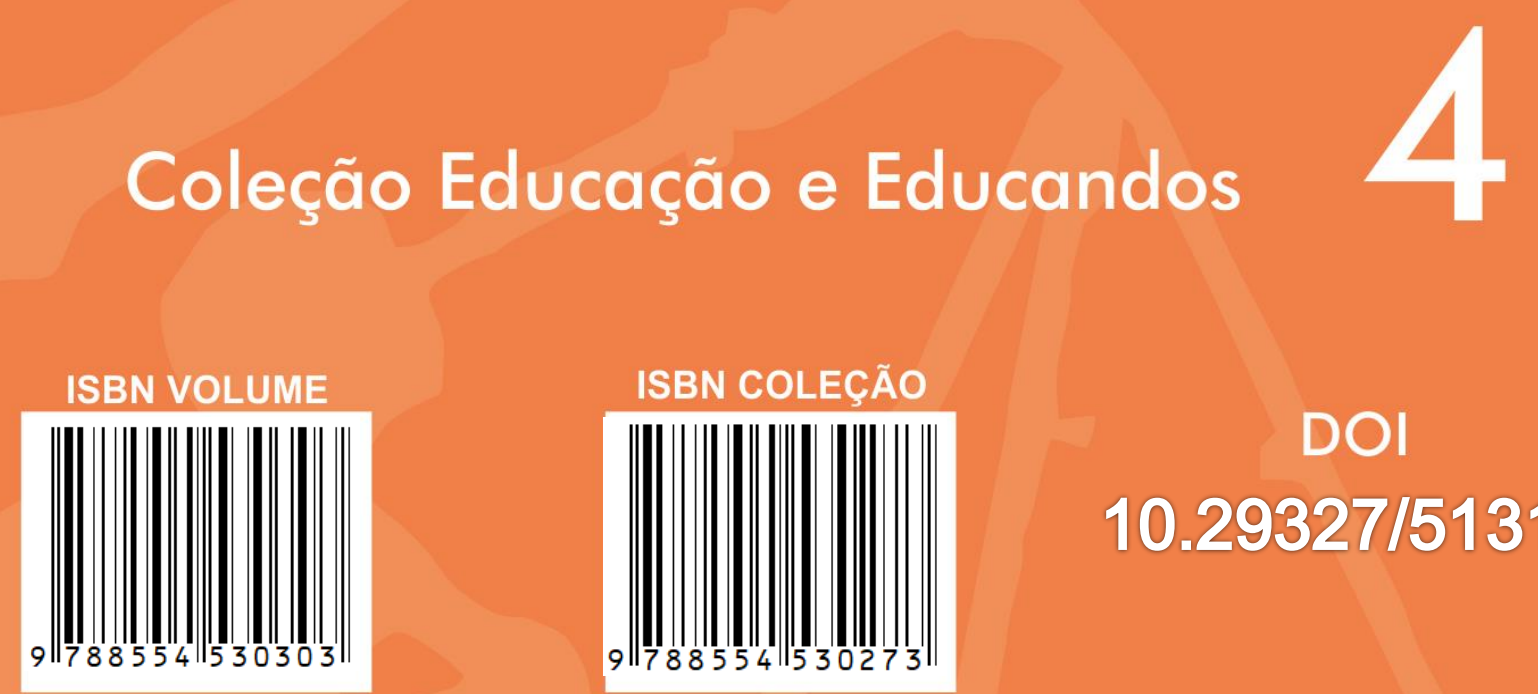

DOI

$10.29327 / 513169$ 

FORMAÇÃO DOCENTE: um processo em contínua construção de conhecimento 
FORMAÇÃO DOCENTE: UM PROCESSO EM CONTÍNUA CONSTRUÇÃO DE CONHECIMENTOS ISBN: 978-85-5453-030-3

Sheila Fernandes Pimenta e Oliveira

Vânia de Fátima Martino

Genaro Alvarenga Fonseca

Tatiana Noronha de Souza (org.)

FORMAÇÃO DOCENTE: um processo em contínua construção de conhecimento

ISBN 978-85-5453-030-3

FRANCA

Uni-FACEF/UNESP 


\section{9 \\ Comissão Científica}

Alessandra David (Centro Universitário Moura Lacerda)

Ana Lúcia Furquim Campos-Toscano (Uni-FACEF)

Célia Maria David (UNESP)

Fernando Silva Ribeiro (Universidade Estadual de Goiás)

Genaro Alvarenga Fonseca (UNESP)

Hilda Maria Gonçalves da Silva (UNESP)

Joana Correa Goulart (Universidade Estadual de Goiás)

Karina de Melo Conte (Centro Universitário Claretiano)

Karina Elizabeth Serrazes (Centro Universitário Claretiano)

Lucinda de Fátima Maria Coelho Rodrigues (Uni-FACEF)

Lucimary Bernabé Pedrosa de Andrade (FFCL)

Márcia Pereira da Silva (UNESP)

Maria Eloísa de Souza Ivan (Uni-FACEF)

Maria Madalena Graciloi (FFCL)

Maria Sílvia Pereira Rodrigues Alves Barbosa ((Uni-FACEF)

Pricila Bertanha (Centro Universitário Claretiano)

Sheila Fernandes Pimenta e Oliveira (Uni-FACEF)

Sílvia Regina Viel (Uni-FACEF)

Sílvio Carvalho Neto (Uni-FACEF)

Vânia de Fátima Martino (UNESP)

Tatiana Noronha de Souza (UNESP)

Welton Roberto Silva (Uni-FACEF)

\section{Conselho Editorial}

Ana Cláudia da Silva (UnB)

Antônio Carlos Petean (UFU)

Daniela Melaré Vieira Barros - Universidade Aberta / Portugal

Danilo Seithi Kato (UFTM)

Genaro Alvarenga Fonseca (UNESP)

Sheila Fernandes Pimenta e Oliveira ((Uni-FACEF)

Sílvio Carvalho Neto (Uni-FACEF)

Teise de Oliveira Guaranha Garcia - FFCLRP / USP

Vânia de Fátima Martino (UNESP) 
FORMAÇÃO DOCENTE: UM PROCESSO EM CONTÍNUA

(C) 2019 dos autores

Direitos de publicação Uni-FACEF

www.unifacef.com.br

Coleção: Educação e Educandos, v.4. 


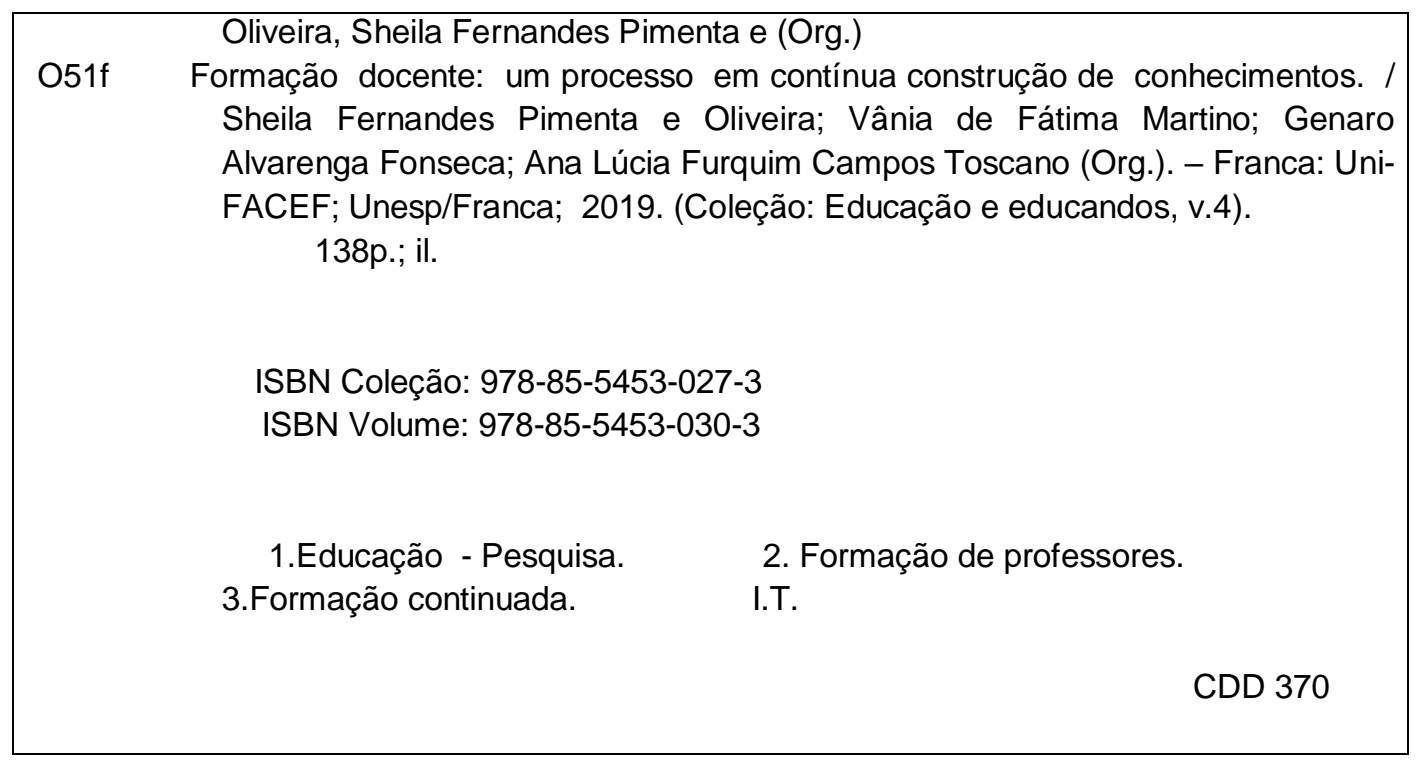

TODOS OS DIREITOS RESERVADOS.

É proibida a reprodução total ou parcial, de qualquer forma ou por qualquer meio. A violação dos direitos de autor (lei no. 9.610/98) é crime estabelecido pelo artigo 184 do código Penal. Todo o conteúdo apresentado neste livro é de responsabilidade exclusiva de seus autores.

Editora Uni-FACEF Centro Universitário Municipal de Franca Associada à ABEC - Associação Brasileira de Editores Científicos 


\section{PREFÁCIO}

Pensar as Práticas Pedagógicas é se abrir para inúmeras possibilidades de exame da realidade escolar, a partir dos lugares ocupados por profissionais de diferentes áreas. Essa riqueza foi verificada nos trabalhos submetidos ao VII Simpósio de Educação e IV Encontro Internacional de Políticas Públicas em Educação, realizados em setembro de 2019 pelo Centro Universitário Municipal de Franca (Uni-Facef) e pela Faculdade de Ciências Humanas e Sociais (UNESP/Franca).

As Práticas Pedagógicas não se limitam às ações restritas às salas de aula, com vistas a ensinar conteúdos curriculares, mas incluem o planejamento sistematizado das ações, a consideração sobre os diferentes processos que ocorrem no momento da aprendizagem, o conhecimento a respeito da realidade social e psíquica dos alunos. Devem, ainda, mobilizar diferentes saberes e conhecimentos dos professores para lidar com a diversidade, estabelecendo uma relação dialógica com os aprendizes. Essas práticas só fazem sentido no coletivo, a partir do diálogo e da mediação do professor, num eterno ajuste e reajuste de ações, realizado a partir da avaliação contínua da ação pedagógica.

Considerando a complexidade de ações e diálogos que compõem as Práticas Pedagógicas, o presente livro apresenta trabalhos que se originam de diferentes áreas do conhecimento, e trazem referenciais teóricos que guiam a avaliação de diferentes estratégias do trabalho educativo. São trabalhos que circulam pelos desafios da inclusão escolar e da relação de ensino com pessoas que saíram do cárcere, juntamente com formação inicial de professores e formação de tutores. Caminha para o ensino de conteúdos específicos, como história, alfabetização, língua portuguesa, educação física, música, literatura e geometria, e inclui o uso da fotografia e as reflexões sobre a interdisciplinaridade necessária e presente nas práticas pedagógicas.

São diferentes pesquisadores na busca de respostas para a implementação de novas formas de ensinar, novas formas de pensar as relações de ensino e procurar garantir o sucesso dos processos de aprendizagem. Uma produção de conhecimento que precisa estar acessível à comunidade externa e escolar, que também procuram soluções para os desafios dos problemas educacionais e precisam ter acesso ao conhecimento científico produzido pelas universidades. 
Que os conteúdos desses textos possam inspirar novas pesquisas e propostas de ações pedagógicas em diferentes espaços educacionais, e por diferentes profissionais da educação. Que sejam lidos e deles retiradas novas perguntas, para assim podermos avançar na produção do conhecimento científico sobre as Práticas Pedagógicas escolares.

Prof ${ }^{a}$ Dr ${ }^{a}$ Tatiana Noronha de Souza Docente da Universidade Estadual Paulista "Júlio de Mesquita Filho" Unesp/Jaboticabal 


\section{SUMÁRIO}

A MULHER QUE MATOU OS PEIXES E QUASE DE VERDADE: investigações preliminares da vertente infantil da poética clariciana

A PERSPECTIVA DO TEMPO A PARTIR DO POEMA "O RELÓGIO" DE VINICIUS DE MORAES E A OBRA “RELÓGIOS MOLES” DE SALVADOR DALÍ ..18 CONTRIBUIÇÕES DAS NARRATIVAS AUTOBIOGRÁFICAS SOBRE A VIDA NA INFÂNCIA EM CONTEXTO DE FORMAÇÃO LÚDICA DE PROFESSORES ...34 EDUCAÇÃO, PESQUISA E DESENVOLVIMENTO: O passado que repercute no presente $e$ as tendências rumo ao humanismo

ESTÁGIO DOCÊNCIA NA FORMAÇÃO DO DOCENTE DO ENSINO SUPERIOR: relato de experiência

PRODUÇÃO DO CONHECIMENTO EM REDE: Um estudo junto a professores da rede pública.

REFLETINDO SOBRE A MODALIDADE DE PESQUISA "ESTADO DA ARTE" ....94 REFLEXÕES QUE EMERGEM DO RESIDÊNCIA PEDAGÓGICA: A vivência dos licenciandos dos cursos de Letras e Matemática no projeto do Uni-FACEF ..114 UM OLHAR SOBRE AS CONTRIBUIÇÕES DO PROGRAMA RESIDÊNCIA PEDAGÓGICA PARA A FORMAÇÃO DE PROFESSORES 126 ÍNDICE 138 


\title{
A MULHER QUE MATOU OS PEIXES E QUASE DE VERDADE: investigações preliminares da vertente infantil da poética Clariciana
}

\author{
AZEVEDO, Gabriela Herculano \\ Graduanda em Letras - Uni-FACEF \\ gaabihazevedo@yahoo.com \\ IVAN, Maria Eloísa de Souza \\ Doutora em Estudos Literários - Uni-FACEF \\ meloisaivan@gmail.com
}

\section{INTRODUÇÃO}

O trabalho que aqui se apresenta justifica-se, inicialmente, como requisito obrigatório para obtenção de bolsa auxílio à Iniciação Científica do UniFACEF, Centro Universitário Municipal de Franca, a ser desenvolvido entre os meses de agosto de 2019 a agosto de 2020, e, por conseguinte, aprovado pela banca examinadora com bolsa IC - Uni-FACEF. Trata-se, então, de pesquisa inicial e em desenvolvimento, portanto, não tendo, ainda, resultados a serem demonstrados.

O encantamento pelas obras de Clarice Lispector é algo que se faz presente em minha vida desde o Ensino Médio, provocando-me e causando-me o "estranhamento" necessário a cada nova leitura, a cada novo encontro com a obra dessa autora. Esse encantamento cresceu ainda mais na graduação quando pude aprofundar os estudos sobre Clarice Lispector e suas obras, e o que era admiração passou a ser objeto de desejo para se avançar em águas mais profundas da escrita clariciana.

O primeiro passo desse percurso foi a escrita do projeto de pesquisa realizado no ano de 2018, com o título: POR ENTRE RUAS, FESTAS E ROSAS: um passeio pela memória em Felicidade clandestina, de Clarice Lispector, que foi finalizado com o artigo científico entregue em agosto de 2019.

Ainda desejando conhecer mais da escrita dessa autora, aliada a uma identificação também com a literatura infantojuvenil, surgiu o tema desta pesquisa: apresentar uma leitura analítica e interpretativa do discurso clariciano em suas obras infantojuvenis, mais especificamente em: A mulher que matou os peixes (1968) e Quase de verdade, de 1978, obra de publicação póstuma.

Naturalizada brasileira, Clarice Lispector nasceu em Tchechelnik, uma aldeia da Ucrânia. Contudo, fugindo à perseguição aos judeus, após a revolução 
Bolchevique (1917), a pequena Haia e a família Lispector desembarcam no Brasil, especificamente em Alagoas, em 1922. Ainda muito jovem, Clarice Lispector descobre o mundo da literatura e em seus textos já se percebiam traços que, posteriormente, se tornariam complexos, pois ao contrário das crianças de mesma idade, Lispector falava sobre sensações, pensamentos, ou ainda, coisas aparentemente sem clareza, o que era motivo de rejeição a tais textos. A criança nunca tivera um texto seu publicado na coluna infantil de o Diário de Pernambuco, o que lhe causava grande frustração.

Inserida na terceira fase do Modernismo Brasileiro, movimento marcado pela ruptura de códigos literários do primeiro vintênio do século $X X$, Clarice Lispector surge no cenário literário brasileiro impactando a crítica com seu discurso existencialista e de introspecção psicológica, diferenciando-se da vertente regionalista abordada até então. Autora de uma vasta obra, Lispector produziu uma diversidade de gêneros: romances, contos, novelas, crônicas, entrevistas, os livros infantis e outros, todos eles resistindo às tentativas de classificações e definições. Segundo a crítica literária (CANDIDO, 1977), a inovação da autora não está apenas na temática apresentada, mas também na materialização de seu discurso. Utilizando-se de um discurso altamente poético, em que os recursos estruturais do gênero lírico se fazem constantemente presentes, a obra clariciana é nomeada pela crítica de "prosa-poética".

A produção infantil clariciana é iniciada no ano de 1967, com a publicação de $\mathrm{O}$ mistério do coelho pensante, obra escrita atendendo ao pedido do filho mais novo, Paulo. Em sua segunda obra infantojuvenil, A mulher que matou os peixes (1968), repete-se a circunstância do ambiente familiar, e agora é Pedro, o filho mais velho, que motiva a história, pois o garoto tinha uns peixes vermelhos, dos quais gostava muito, mas tendo feito uma viagem de um mês, pede que a mãe cuide dos bichinhos; contudo, Lispector, concentrada nas histórias que estava escrevendo, se esquece de lhes dar comida durante três dias e os pexinhos morrem; portanto, a história tem como mote um fato real (GOTLIB, 1995).

Em 1977, Lispector declara que está escrevendo o seu quarto livro infantil. Trata-se do futuro Quase de verdade, publicado postumamente, em 1978. Nesse livro, a autora dá a palavra ao cão Ulisses, que é o narrador da história.

A obra se estrutura, portanto, sob o caráter de fábula, esta que segundo Coelho (2000), ao julgar pelo que a história registra, foi a primeira espécie de narrativa a aparecer; sua origem se encontra no Oriente e foi reinventada no Ocidente pelo grego Esopo (séc. VI. a.C.) e, séculos mais tarde, aperfeiçoada pelo escravo Fedro (séc. I a.C.), enriquecendo-a estilisticamente, mas foi no séc. XVII que La Fontaine a introduziu definitivamente na literatura ocidental.

A fábula (lat. fari = falar e gr. phaó = dizer, contar algo) é a narrativa de natureza simbólica, cuja peculiaridade, que a distingue das demais espécies metafóricas ou simbólicas, é a presença do animal colocado em uma situação humana e exemplar. Suas personagens são sempre simbólicas, isto é, representam 
algo num contexto universal, já que desde os tempos mais remotos, tal simbolismo tem sido uma das invenções mais curiosas do homem como expressão de seu conhecimento de mundo.

Importante presença no mundo da literatura, os animais continuam sendo uma fonte de sugestões para a invenção de histórias atraentes para crianças e adultos, é o caso da maior parte das obras de Lispector destinadas ao público infantil que são regidas por personagens na forma de animais, como o cão narrador da obra Quase de Verdade (1978).

Uma apresentação mais detalhada das duas obras será feita durante a realização desta pesquisa, no entanto, para este projeto, faz-se necessário contextualizar o leitor, ainda que sucintamente, acerca da literatura infanto-juvenil e de seu discurso plurissignificativo, pois consideramos que a formação de leitores críticos acontece em um processo que vai desde sua primeira fase escolar, até a juventude propriamente dita.

Coelho (1991) diz que uma das hipóteses do surgimento da literatura infantil é o fato de que é uma característica intrínseca ao ser humano o contar histórias, pois é da essência do homem ter a necessidade e o impulso de contar algo, trocar experiências. Embora essas histórias não tenham sido transcritas em material perene, ou duradouro elas atravessaram séculos e foram preservadas pela memória dos povos, mais que isso, foram passadas de geração para geração, sempre um contando ao outro e assim por diante.

Para Coelho (2000), a literatura tem o intuito de alertar ou transformar a consciência crítica de seu leitor e desde suas origens aparece entrelaçada a essa função essencial: atuar sobre as mentes, nas quais se decidem as vontades ou ações e, no encontro com a literatura (ou arte em geral), os homens têm a oportunidade de ampliar, transformar e enriquecer sua própria experiência de vida em um grau de intensidade não igualada por nenhuma outra atividade.

A literatura infanto-juvenil possui um caráter atemporal, que permite um revisitar constante e a reflexão acerca da condição humana, alimentando a imaginação de todos nós, de geração em geração. Essa é uma das artes que enriquece os sonhos e a criatividade não só da criança como do homem de todos os tempos, proporcionando ensinamentos sem limitações de espaço, tempo ou idade.

Contudo, surgiram dúvidas quanto à literariedade da literatura infantil, pois em certo momento, o das primeiras publicações, escritas por pedagogos, há um forte intuito educativo e com isso, perde-se a literariedade, não sendo esta produção considerada arte. Todavia, essa literatura nem sempre é subserviente à pedagogia, e sempre que há qualidade estética, valor artístico, a literatura infanto-juvenil é vista como arte, afastando-se do seu valor pragmático e comprometido com a pedagogia.

$\mathrm{E}$, neste contexto, a literatura infanto-juvenil, enquanto arte da palavra simbólica e plurissignificativa, e não subserviente aos critérios da pedagogia, se apresenta como instrumento eficiente quando permite ao leitor correr livre para a A MULHER QUE MATOU OS PEIXES E QUASE DE VERDADE: investigações preliminares 
fantasia, podendo refletir sobre sua condição pessoal. E, afinal, como disse Drummond (1944), "qual o bom livro para crianças, que não seja lido com interesse pelo homem feito?". Clarice Lispector, também em suas obras infanto-juvenis, corrobora a literariedade de seus textos e do seu teor reflexivo, a partir de um discurso figurado, que incomoda, provoca o leitor e lhe possibilita o alargamento de horizontes necessário.

Assim, de acordo com Lajolo e Ziberman (2004), a literatura infantojuvenil, enquanto gênero escrito, veio a público somente no século XVII, com a publicação de Contos da Mamãe Gansa (1697), de Charles Perrault. Para as ensaístas, a valorização da criança como ser pensante, autônomo é conquista recente; dar voz e importância às crianças foi um processo longo, que passou por questões sociais, econômicas e históricas que atingem hoje um estágio de maturidade resultante do surto de criação e dos estudos teóricos e críticos de que vem essa literatura.

Nelly Novaes Coelho (2000) observa que a expressão "literatura infantil" sugere, de imediato, a ideia de livros coloridos, para a distração e o prazer das crianças em lê-los, folheá-los ou ouvir suas histórias contadas por alguém. Devido a essa função básica, até há pouco tempo, a literatura infantil foi minimizada como criação literária e tratada pela cultura oficial como um gênero menor. Contudo, essa visão errônea vem se desfazendo ao longo das últimas décadas e hoje a literatura infanto-juvenil é vista, antes de tudo, como literatura, arte da palavra simbólica e plurissignificativa.

Neste ponto, o ato de ler se transforma em um ato de aprendizagem onde uma mensagem é transmitida de um autor-adulto, que apresenta uma experiência do real, para um leitor-criança que adquire tal experiência. A literatura infantojuvenil, ou para adulto está atrelada ao ato de reflexão, de provocação, do incômodo produtivo e precisa, urgentemente, ser descoberta menos como objeto de entretenimento e mais como uma aventura espiritual que engaje o eu em uma experiência rica de vida, inteligência e emoções.

Por todas essas razões e por aquelas que ainda estão por vir, nos encantamos por essa literatura e, conforme dito anteriormente, a autora escolhida para nossa pesquisa foi Clarice Lispector e duas de suas obras infantis, a saber: A mulher que matou os peixes (1968) e Quase de verdade, de 1978,que constituem o corpus deste estudo preliminar.

Dentre os diversos escritores conhecidos e reconhecidos na literatura infantil brasileira, estão Monteiro Lobato, Ana Maria Machado, Lygia Bojunga e Ruth Rocha; no entanto, autores da vertente "adulta" também se enveredaram para a produção infanto-juvenil e, nesse contexto, nos deparamos com a autora Clarice Lispector.

O discurso de Lispector pode ser visto como clássico, atemporal, universal, pois reflete os questionamentos do homem de todos os tempos e lugares 
e esta pesquisa amplia nossos conhecimentos no que se refere à construção da poética clariciana, presente, principalmente, em suas obras infantis, uma vez que seu discurso, também ali, marca e define o estilo clariciano, pois os livros infantis publicados pela autora trazem para a literatura infantil a perplexidade $\mathrm{e} a$ insegurança do narrador moderno. As cinco obras que compõem essa vertente da produção clariciana são: O mistério do coelho pensante (1967), A vida íntima de Laura (1974), Como nasceram as estrelas (1987), A mulher que matou os peixes (1968) e Quase de verdade (1978). Os dois últimos livros citados compõem o corpus desta pesquisa.

A partir da leitura realizada, pode-se perceber nas duas obras, o estilo da narrativa clariciana, que nos apresenta uma forma de relação com a criança bastante distinta da encontrada em grande parte das obras infantis. Os narradores claricianos não se travestem de criança para alcançar uma aproximação com o universo dos destinatários (OLIVEIRA, 1998, p.126). Isso acontece justamente porque uma forma de se aproximar do leitor, é se dirigindo diretamente a ele, como faz Clarice: "Antes de começar, quero que vocês saibam que meu nome é Clarice. $E$ vocês, como se chamam? Digam baixinho o nome de vocês e o meu coração vai ouvir. Peço que leiam essa história até o fim" (LISPECTOR, 1999, p. 9).

Por essa breve apresentação das duas obras é possível perceber a riqueza discursiva e semântica também na produção infantil da autora. São obras que exigem do leitor um olhar mais atento, pois apesar da grande quantidade de estudos críticos sobre Lispector, quando nos deparamos com a vertente infantil da escrita clariciana há uma escassez de estudos que chega a causar estranhamento, mas também nos provoca a seguir adiante.

Assim, acreditamos que a relevância desta pesquisa não está apenas em discutir a literariedade do discurso da Literatura Infanto-juvenil e os traços estilísticos que compõem a produção infantil de Clarice Lispector, mas está, também, em ampliar nossos conhecimentos em relação à essa vertente da produção da autora, que é ainda pouco estudada, merecendo um olhar cuidadoso e profundo, que possibilite uma contribuição científica para o conhecimento da vida e obra de Lispector, enfatizando-se uma outra vertente de sua escrita, que só mais recentemente tem recebido maior atenção por parte de estudiosos da obra clariciana.

Este trabalho orienta-se por uma pesquisa bibliográfica, cuja metodologia será apresentada na sequência dos objetivos.

\section{OBJETIVOS}

O objetivo desta pesquisa é o de verificar, por meio de uma leitura analítica e interpretativa, os efeitos de sentido criados pelo discurso clariciano na sua produção infantil, mais especificamente em duas obras, a saber: A mulher que matou os peixes (1968) e Quase de verdade (1978). 
A fim de alcançar o objetivo proposto, fixamos nossa análise nos procedimentos narrativos das obras acima referenciadas, destacando-se as possibilidades de construção estética, procedentes do relacionamento especial da linguagem com o universo infantil, o qual passa a ser visto como um precioso subsídio para a criação literária. Portanto, é no sentido de vislumbrar diferentes jogos com a linguagem que orientamos a leitura das obras infantis claricianas que, desse modo, demarcam um lugar importante no conjunto da produção da escritora, contribuindo para a sua interpretação.

Parte-se da hipótese de que apesar dos inúmeros trabalhos publicados periodicamente sobre a obra de Lispector, há, ainda, muito a se dizer, pois conforme atestamos anteriormente, o tema proposto por essa pesquisa é ainda bem pouco explorado, carecendo de um olhar mais atento do pesquisador.

Assim, por meio de uma leitura analítica e interpretativa, objetiva-se uma análise textual, em que se verificam os efeitos de sentido revelados na literatura infanto-juvenil de Lispector, que materializa sensações, impressões e sentimentos, evidenciando-se seu estilo, sua poética também ali, em livros infantojuvenis.

\section{METODOLOGIA}

A abordagem desta pesquisa, ainda preliminar, é teórica e encontra-se na área da Literatura Infanto-juvenil Brasileira, cujo suporte provém de pesquisa bibliográfica, tanto no que diz respeito à contextualização da autora e das obras, quanto aos estudos sobre os procedimentos narrativos adotados por Lispector na elaboração de suas obras infantis.

Acreditando-se, então, na possibilidade de oferecermos um novo olhar para essa vertente da produção clariciana, buscaremos, no decorrer desta pesquisa, responder aos seguintes questionamentos:

1. Como se constitui a Literatura Infanto-juvenil Brasileira dentro de um contexto de tradição e renovação?

2. Quais são os mecanismos de construção da poética de Clarice Lispector, mais especificamente nas obras A mulher que matou os peixes (1968) e Quase de verdade (1978), corpus desta pesquisa?

3. Quais os efeitos de sentido materializados pelos procedimentos narrativos, a saber, enredo, narrador, personagem, tempo e espaço, nas duas obras em questão?

4. É possível afirmar que a vertente infantil de Lispector confirma o estilo clariciano?

O embasamento teórico está fundamentado em leituras de textos teóricos e ensaísticos de autores como Lajolo \& Zilberman (2004), Zilberman (2003), Coelho $(1991 ; 2000)$ e Cademartori (2007) para falar sobre a literatura infantojuvenil. Acerca da vida e obra de Clarice Lispector, nos utilizaremos das reflexões de estudiosos da obra clariciana, a saber, Candido (1977), Gotlib (1995), Moser (2011), 
Nunes (1995), Ivan (2001; 2005; 2015), Rosenbaum (2002). Concernente à produção infantil da autora serão utilizados os apontamentos feitos por Oliveira (1998), Filipouski (1998), entre outras fontes.

\section{CRONOGRAMA}

\begin{tabular}{|l|c|c|}
\hline \multicolumn{1}{|c|}{ Etapas } & Início & Término \\
\hline 1. Definição de bibliografia básica & $08 / 2019$ & $08 / 2019$ \\
\hline 2. Análise e fichamento de leituras & $09 / 2019$ & $04 / 2020$ \\
\hline 3. Definição e desenvolvimento da pesquisa & $09 / 2019$ & $05 / 2020$ \\
\hline 4. Coleta de dados & $08 / 2019$ & $05 / 2020$ \\
\hline 5. Sistematização de resultados & $10 / 2019$ & $06 / 2020$ \\
\hline 6. Elaboração da redação & $10 / 2019$ & $06 / 2020$ \\
\hline 7. Digitação do trabalho & $10 / 2019$ & $07 / 2020$ \\
\hline 8. Entrega do trabalho & $08 / 2019$ & $08 / 2020$ \\
\hline
\end{tabular}

\section{REFERÊNCIAS PRELIMINARES}

ARÊAS, Vilma. Children's Corner. In dedos. São Paulo: Companhia das Letras, 2005.

Clarice Lispector: com a ponta dos

BÍBLIA SAGRADA. São Paulo: Ave Maria, 181. ed, 2008.

BOITANI, Piero. A sombra de Ulisses. São Paulo, Ed. Ponto perspectivo, 2005.

BOSI, Alfredo. História concisa da literatura brasileira. São Paulo: Cultrix, 1994.

CANDIDO, A; CASTELLO, José Aderaldo. Presença da literatura brasileira: Modernismo história e antologia. 11.ed. Rio de Janeiro: Bertrand, 2003.

CANDIDO, A. No raiar de Clarice Lispector. In: Vários escritos. 2. ed. São

Paulo: Livraria Duas cidades, 1977.

CHEVALIER, Jean; GHEERBRANT, Alain. Dicionário de Símbolos: mitos, sonhos, costumes, gestos, formas, figuras, cores, números. 18.ed. Rio de Janeiro: José Olympio, 2009.

COELHO, Nelly Novaes. Panorama Histórico da Literatura infantojuvenil. 14. ed. São Paulo: Ática, 1991.

. Literatura infantil: teoria-análise-didática. 1.ed. São Paulo: Moderna, 2000. 
Dicionário crítico da literatura infantil e juvenil brasileira. 5. ed. São Paulo: Companhia editorial nacional, 2006

FILIPOUSKI, Ana Maria Ribeiro. Um espaço de hesitação da narrativa infantil: o narrador em busca de diálogo com o leitor. In. ZILBERMAN, Regina (org). Clarice Lispector: A narração do indizível. Porto Alegre: Artes e Ofícios, 1998, p. 129-144.

FIORIN, José Luiz. Interdiscursividade e intertextualidade. In (org). Bakhtin: Outros conceitos chave. São Paulo: Contexto, 2006.

BRAIT, Beth

GOTLIB, Nádia B. Clarice: uma vida que se conta. São Paulo: Ática, 1995.

GREGORIN, Jose Nicolau Filho. Literatura infantil: múltiplas linguagens na formação de leitores. São Paulo: Melhoramentos, 2010.

IVAN, Maria Eloisa. Um Narrador se sua criatura: uma leitura do duplo em Um sopro de vida, de Clarice Lispector. 2015, 156 f. (Tese de doutorado em Estudos Literários) Universidade Presbiteriana Mackenzie: São Paulo, 2015.

O leitor e o texto: o diálogo possível. In: Revista científica da Fundação Educacional de Ituverava. Ituverava, NUCLEUS. 2005, p. 103-112.

A hora da estrela: uma narrativa especular. Araraquara, 2001. Dissertação (Mestrado em Estudos Literários). Faculdade de Ciências e Letras da Universidade Estadual Paulista "Júlio de Mesquita Filho" - Araraquara/SP.

LAJOLO, Marisa \& ZILBERMAN, Regina. Literatura Infantil Brasileira: História e histórias. 6. Ed. São Paulo: Ática, 2004.

LISPECTOR, Clarice. Quase de verdade. Rio de Janeiro: Rocco, 1999. A mulher que matou os peixes. Rio de Janeiro: Rocco, 1999.

MOSER, Benjamin. Clarice, uma biografia. Tradução de José Geraldo Couto. 2. ed. São Paulo: Cosac Naify, 2011.

NUNES, Benedito. O drama da linguagem: uma leitura de Clarice Lispector. São Paulo: Ática, 1995. 
OLIVEIRA, Rejane Pimenta de. Brincadeira de narrar. In ZILBERMAN, Regina (org). Clarice Lispector: a narração do indizível. Porto Alegre: Artes e Ofícios, 1998,p.105-127.

ROSENBAUM, Yudith. Clarice Lispector. São Paulo: Publifolha, 2002.

SILVA, Vera Maria Tietzmann. Literatura infantil brasileira: um guia para professores e promotores de leitura. 2. ed. Goiânia: Cânone Editorial, 2009.

ZILBERMAN, Regina. A literatura infantil na escola. 11. Ed. São Paulo: Global, 2003. 


\title{
A PERSPECTIVA DO TEMPO A PARTIR DO POEMA "O RELÓGIO”' DE VINICIUS DE MORAES E A OBRA ‘RELÓGIOS MOLES" DE SALVADOR DALÍ
}

\author{
MOREIRA, Gabriela Fernanda \\ Graduanda em Matemática - Uni-FACEF \\ moreirafernandagabriela@gmail.com \\ ALVES, Mauricio Conrado \\ Graduando em Matemática - Uni-FACEF \\ mconrado193@gmail.com
}

COELHO, Lucinda Maria de Fátima Rodrigues

Docente - Uni-FACEF

lucindarcoelho@gmail.com

\section{INTRODUÇÃO}

Este trabalho vincula-se ao Programa Institucional de Bolsa de Iniciação à Docência, PIBID/CAPES-Uni-FACEF 2018/2019 que, em uma abordagem interdisciplinar, envolve os cursos de licenciaturas em Letras e Matemática do Centro Universitário Municipal de Franca- Uni-FACEF a fim de conciliar a leitura de textos literários à linguagem matemática. Este programa está sendo desenvolvido junto aos alunos dos sextos, sétimos, oitavos e nonos anos do Ensino Fundamental II das Escolas Estaduais José Pinheiro de Lacerda e E.E. David Carneiro Ewbank da cidade de Franca-SP, com o objetivo principal de desenvolver competências e habilidades para a leitura e compreensão de textos literários, bem como da linguagem matemática apresentada em situações-problema.

Trabalhou-se, em 2018, o gênero narrativo tendo como corpus à obra A bolsa amarela, de Lygia Bojunga. Em 2019, privilegiou-se, no primeiro semestre, o gênero lírico com o poeta Mário Quintana e a geometria euclidiana por meio das obras do artista plástico Eduardo Kobra. Finalizado o trabalho com Mario Quintana, o poeta escolhido foi Vinícius de Moraes e seu trabalho com os sonetos apresentados em poemas que se utilizavam de temas como o amor e a amizade tão caros ao poeta. Posteriormente, a sua produção infantojuvenil tem início no ano de 1950 momento em que a carreira do diplomata e literário-jornalístico está a todo vapor. Algumas de suas obras poéticas de Vinicius foram criados em inspiração aos seus filhos Susana (1940), Pedro (1942), Georgiana (1953) e Luciana (1956) que permaneceram guardados por 
muitos anos até serem publicados em 1970, tornando-se esse um dos livros mais populares de Vinícius de Moraes.

O livro A arca de Noé é uma composição infanto-juvenil que é lançada em 1970, quando nasce sua filha Maria (a caçula), a obra vem composta de 20 temas: "A Arca de Noé", "São Francisco", "Natal", "O Girassol", "O Relógio", "O Pinguim", "O Elefantinho", “A Porta”, "O Leão”, "O Pato”, “A Cachorrinha”, "A Galinha-d'angola", “O Peru”, "O Gato”, “As Borboletas”, "O Marimbondo", "As Abelhas", "A Foca", "O Mosquito" e "A Casa", e por meio desta data firma-se uma carreira e o início de uma grande amizade com o instrumentalista Toquinho, que duraria até o último dia de sua vida. Para a sequência didática apresentada neste artigo destacou-se os poemas "O relógio" e a "A casa", conforme dito antes, pertencentes à obra acima referenciada, promovendo o caráter interdisciplinar entre Letras e Matemática e estabelecendo-se, ainda, um elo com as artes plásticas, associou-se o poema "O relógio" à obra intitulada "A Persistência da Memória " ou " Relógios Moles", cujo autor foi Salvador Dali (1904-1989), um pintor espanhol (catalão) radicado em Paris e uma das maiores expressões do Surrealismo.

A partir das duas linguagens desenvolveram-se os conceitos da geometria euclidiana tais como: o círculo, a circunferência e os ângulos em exercícios práticos, que tiveram como referência bibliográfica provas realizadas em escolas públicas, tais como SARESP/OBMEP. Como procedimento teóricometodológico, adotou-se uma pesquisa de abordagem bibliográfica. $O$ embasamento teórico acerca de sequências didáticas está fundamentado nas reflexões propostas por Schneuwly e Dolz (2004). No que se refere à teoria do gênero lírico foram utilizadas as considerações de Goldstein (2004), Rosenfeld (2006), Soares (2004). Os conceitos de geometria foram baseados em Dolce e Pompeo (1997) e a didática matemática em Rosa Neto (2008). Para contextualização dos artistas, foram utilizadas informações veiculadas nos sites oficiais, entre outras fontes.

\section{SEQUÊNCIA DIDÁTICA}

O termo "Sequência Didática" (SD) surgiu em 1996, nas indicações oficiais para o ensino de línguas na França, quando exploradores viram a necessidade de superação da compartimentalização dos conhecimentos no campo do ensino de línguas.

"Sequência" significa "ação de seguir", pode-se dizer que sequências didáticas são "etapas continuadas" ou "conjuntos de atividades" de um tema que tem por objetivo ensinar uma matéria, parte por parte. 
Em seu teste, Dolz, Noverraz e Schneuwly (2004) apresentam um modelo de sequência didática que está basicamente construído e associado às pesquisas sobre a aquisição da língua escrita e gêneros textuais.

Para os estudiosos de Genebra:

Sequência didática é um conjunto de atividades escolares
organizadas, de maneira sistemática, em torno de um gênero
textual oral ou escrito a qual procura favorecer a mudança e a
promoção dos alunos ao domínio dos gêneros e das situações
de comunicação (Dolz, Noverraz \& Schneuwly, 2004: 53).

Ainda para os mesmos autores, as SDs devem ser compreendidas como um conjunto de atividades organizadas, de maneira sistemática, em torno de um gênero textual oral ou escrito. Isto é, entre as ações de uma SD estão as atividades de audição, leitura, escrita e reescrita de textos.

Complementam, ainda, articulando que sequências didáticas são passos ou etapas seguidas, ou um conjunto de atividades sobre um tema com o objetivo de trabalhar um conteúdo etapa por etapa, ligadas entre si, para tornar mais eficaz o processo de aprendizado.

Toda e qualquer SD planejada devem ser composta para atingir um intuito, mas não é qualquer intuito. Esse intuito deve atender as dificuldades do discente. Se é preciso ensinar algo para o discente, é preciso criar um método de passo a passo para que ele seja suficiente para o discente compreender o conteúdo que o professor está oferecendo. Então, é importante selecionar e criar as sequências e ter uma didática apropriada para usar em sala. É preciso saber em qual etapa os discentes se encontram, para, então, partir desses níveis de conhecimento visando chegar aos níveis que eles precisam comandar.

\section{UMA ABORDAGEM DO GÊNERO INFANTO-JUVENIL}

Para melhor entendimento dessa sequência didática utilizamos como ferramenta de estudo a Arca de Noé" álbum infanto-juvenil de Vinicius de Moraes, desfrutando-se do gênero lírico. O gênero lírico refere-se ao tipo de texto literário onde ressalta a expressão de sentimentos e emoções relativa do sujeito lírico. O termo "lírico" originou-se do latim (lyricu) que tem como significado "lira", no qual na Idade Média servia como instrumento musical para os gregos. Por compreender a relevância desse gênero nos quais em muitas oportunidades tem sido ocultado dos livros didáticos e apartado de dentro da sala de aula, desprezando-se o valor deste conteúdo. 
Tendo como objetivo, desconstruir o preconceito gerado entre professor e discentes no que se refere ao texto poético, a fim de estimular o estudo e a leitura. A história da literatura infanto-juvenil inicia-se por volta do século XVIII, pois é a partir dessa data que criança daquela época é vista com um olhar diferente e não mais como adulto, com suas próprias características e necessidades, pois na sociedade antiga não existia um mundo separado do mundo dos adultos, a crianças daquelas épocas vivia semelhantemente tudo que um adulto vivenciava. Desde o seu surgimento, a literatura vem sendo rodeada de preconceitos de sua relevância na função pedagógica e até mesmo artística.

A literatura infanto-juvenil modificou-se muito e absorve uma série de características novas, mas mesmo assim não perdeu seu grande valor histórico e pedagógico. Apesar de ser uma perspectiva da literatura geral tem como seu objetivo direcionar sua escrita a uma determinada faixa etária, pois possuem assuntos com a capacidade de aprimorar o imaginário humano tendo como vista a compreensão e a resolução de conflitos internos de um individua em particular. Monteiro Lobato foi o primeiro autor de literatura infanto-juvenil brasileiro, rompendo-se os padrões literários da Europa, antes deles os textos infanto-juvenil eram apenas adaptações de grandes textos clássicos europeus. Analisando suas obras podemos perceber que ele se apresenta com outro ponto de junção de rendimentos visivelmente opostos: as da traição e as da renovação.

Neste artigo daremos o destaque para o compositor Vinícius de Moraes visando seus poemas infanto-juvenis, o compositor teve vários outros cargos mais afirmava que sua primeira e maior vocação que tem é a de compor poesias. Com objeto de estudo para sequência didática relatada neste artigo utiliza-se do seu grande livro a "A Arca de Noé", esta composição era em inspiração aos seus filhos, que por muito tempo mantém-se guardado, e apenas em 1970 são lançados e ganham o mundo. O lançamento desse livro ocorre na Itália, já que era um lugar onde costumava constantemente estar. E é onde ele forma uma grande amizade com o compositor Toquinho e nem imaginavam que está amizade duraria até o último dia de sua vida. Vinicius ficou conhecido com seus poemas infantis e o livro a "A Arca de Noé", um dos livros mais conhecido de Vinicius que se tornou disco totalmente voltado para as crianças.

\subsection{Poema Relógio: algumas reflexões}

O relógio é uma das composições de Vinicius de Moraes, apesar de suas grandes e maiorias composições tratar de assuntos como o amor, a 
fidelidade, a amizade e a sensualidade, o poeta mostra a sua sensibilidade e inocência com a criação de seus poemas infanto-juvenis. Suas poesias infantis escrita de forma simples e ritmada, levam as crianças e qualquer outro tipo de leitor a imaginação pura e sincera.

A figura de linguagem presente no poema é onomatopeia, este efeito é causado pelo (tic-tac), isto causa a expressão do barulho de um relógio e com isto traz ao poema ritmo e sonoridade. Ao caminhar pelo texto podemos ver que o poeta se utiliza do uso de vírgulas para mostrar as pausas do texto, trazendo o efeito e a imaginação dos ponteiros de um relógio se movendo.

Em relação a escolha do vocabulário notamos que o eu-lírico utilizou-se de palavras relacionadas com o título do texto exemplos: tempo, dia, noite, atrasa, hora e depressa. Essa comparação é própria do tempo, mostrando que o tempo sempre estará em movimento e nunca parado. Em relação a estrutura, as métricas fazem com que refletimos que o tempo vem diminuindo na vida do ser humano, com a correria e a acumulação de tarefas e afazeres.

Num paralelo com as obras de Salvador Dali (Os relógios moles) pode-se fazer uma análise mais profunda na qual somos capazes de enxergar que o eu-lírico carrega um ar de tristeza no verso em que afirma "Já perdi toda alegria", a reflexão que transfere é que o poeta perde o sentido da vida pois já se tornou algo roteiro e não mais prazeroso. Mostra que já está cansado e fadigado daquilo, como afirma o verso "Que já estou muito cansado". Apesar de ser um poema infanto-juvenil está carregado de sentimentos negativos.

\subsection{Salvador Dali e os Relógios Molis}

Salvador Domingo Dalí Domènech nasceu em Figueres, Gerona, Espanha, no dia 11 de maio de 1904. Filho do tabelião Salvador Dalí Cusi e de Felipa Domènech em 1922 muda-se para Madrid. Salvador Dalí (1904-1989) foi um pintor espanhol que se destacou por suas composições incomuns e incoerentes.

Dalí chamava atenção por conta de seu figurino que apresentava sua personalidade extravagante: com cabelos longos, gravata desproporcionalmente grande e uma capa que decorria até seus pés.

Relógios Moles também conhecido como Persistência da Memória (1931), pintado a óleo, criado por Dalí, que no momento de criação teve como inspiração um queijo camembert que ele degustava e ao mesmo tempo observava enquanto pintava-o. 
Figura 1 - Relógios Moles
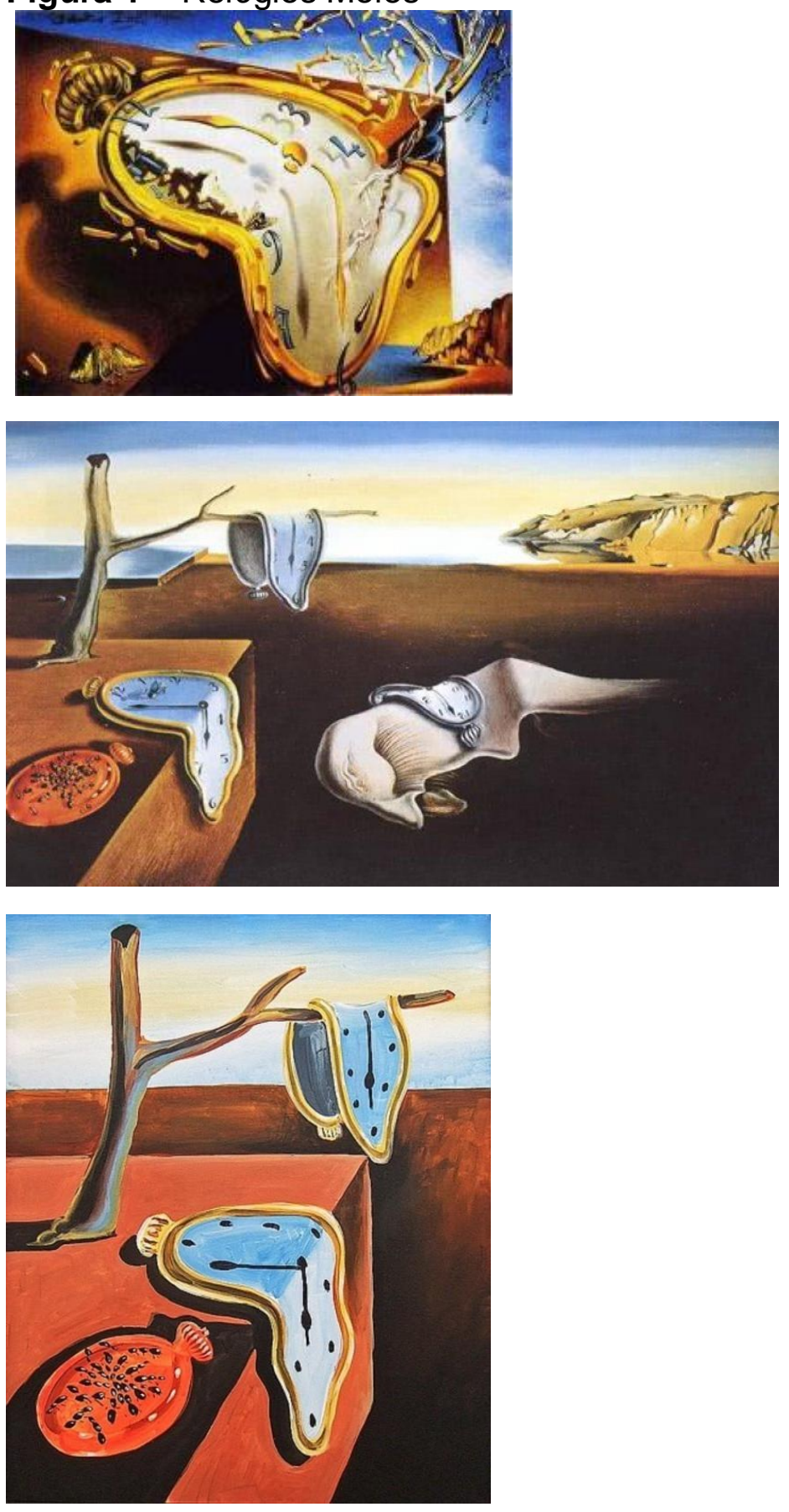

Fonte: Google, 2019.

\section{GEOMETRIA PLANA PARA CONSTRUÇÃO DO RELÓGIO}


Geometria é uma palavra originada do grego, é a junção de "geo" (terra) e "métron" (medir), cujos significados mostram propriedade associadas com a posição em formas de objetos no espaço. A Geometria é o campo da matemática que tem como objetivo aplicar-se a questões tais como: forma, posição relativa, figuras e propriedades do espaço.

Dividindo-se em várias subáreas, como: Geometria Descritiva (cujo objetivo é demonstrar objetos de três dimensões, estabelecer distâncias, ângulos, áreas e volumes em suas verdadeiras grandezas); Geometria Plana (tem como objetivo demonstrar procedimentos de estruturas no plano, a partir de conceitos básicos primitivos como ponto, reta e plano) e por fim a Geometria Analítica (tem como objetivo demonstrar que estuda a geometria plana e espacial por meio de processos algébricos).

\subsection{Ponto, Reta e Plana}

Estes conceitos não são definidos, mas são relevantes para a base teórica. O Ponto é o item que marca a posição inicial ou final, já a reta é uma linha sem interrupção e que não possui curva alguma.

Figura 2 - Conceitos de reta e ponto

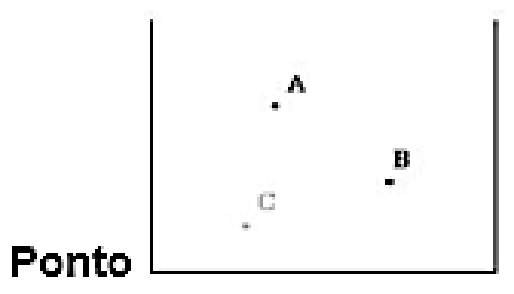

\section{Reta}




\subsection{Circunferência e Círculo}

Muito comum haver confusão entre circunferência e o círculo. Embora utilizarmos esses termos como sinônimos, eles apresentam diferença. Enquanto a circunferência representa a linha curva que limita o círculo (ou disco), este é uma figura limitada pela circunferência, ou seja, representa sua área interna.

Figura 3 - Exemplos de circunferência e círculo
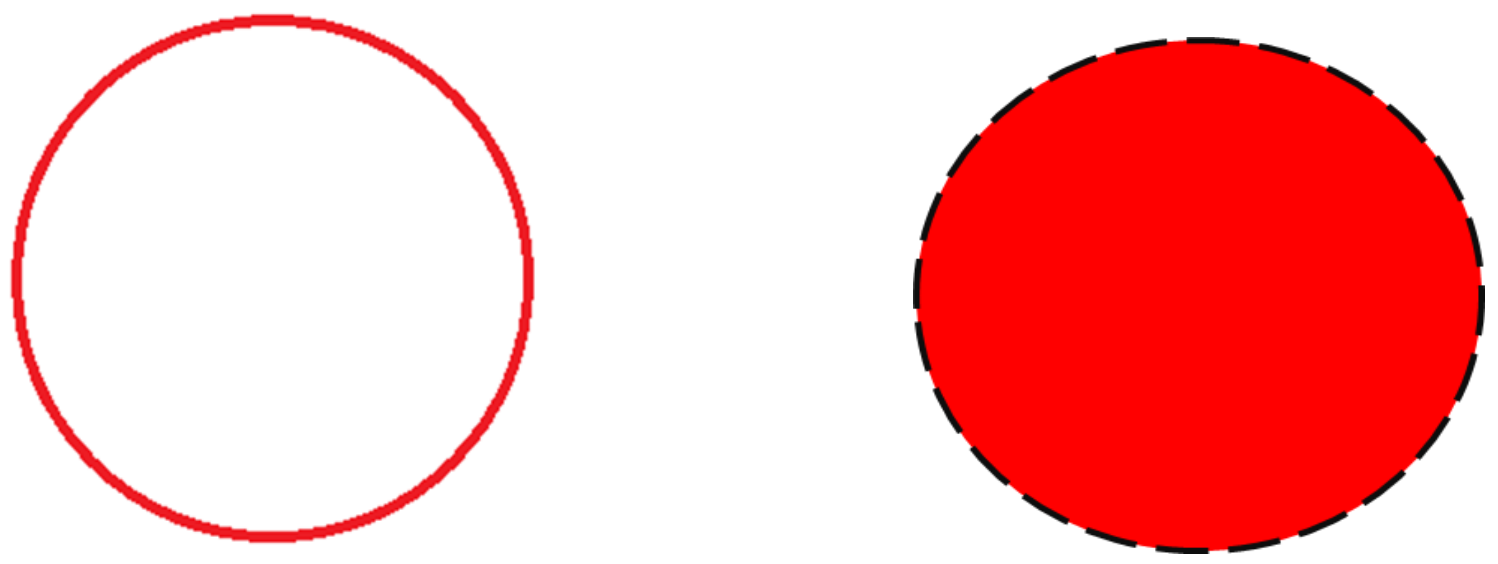

\section{3 Ângulos: por que são medidos em minutos e segundos?}

Tudo culpa dos babilônios, que inventaram um sistema quase dois mil anos antes de Cristo.Minutos e segundos são unidades de medida usadas no sistema sexagesimal, criado pelos babilônios por volta de 1800 antes de Cristo."O sistema usa como base o número 60 , diferente do arábico ou decimal adotado hoje, baseado no 10". Os babilônios criaram o sistema porque 60 é divisível por diversos números como 2; $3 ; 4 ; 5 ; 12 ; 15 ; 20 ; 30$ e 60 diminuindo o uso de frações, com as quais os antigos tinham dificuldade.

Adotar 360 graus - que é 60 multiplicado por 6 - para medir o círculo foi influência do movimento circular aparente do Sol no céu, que leva 365 dias. Ele percorre, em relação aos astros, cerca de 1 grau por dia. Denominamos ângulo a 
região do plano limitado por duas semirretas de mesma origem. As semirretas recebem o nome de lados do ângulo e a origem delas, de vértice do ângulo.

Figura 4 - Ângulos

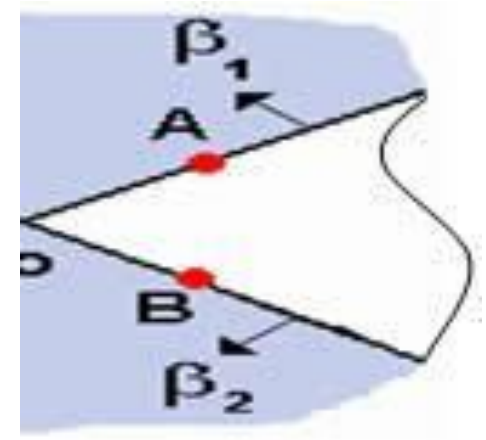

Sistema Sexagesimal Sua unidade principal é o grau (ํ); tem como base a divisão da circunferência em 360 partes iguais, sendo cada uma dessas partes um grau. Possui os submúltiplos minuto (" ) e segundo ("), cujas equivalências são:

$$
1^{\circ}=60^{\prime} \text { e } 1^{\prime}=60^{\prime \prime}
$$

Isto é, $1^{\circ}$ (grau) equivale a 60' (minutos) e 1' equivale a 60" (segundos). O objeto capaz de medir o valor de um ângulo é chamado de transferidor, podendo ele ser de "meia volta" $\left(180^{\circ}\right)$ ou volta inteira $\left(360^{\circ}\right)$. A medida das horas do relógio também usa o sistema sexagesimal.

\subsection{Tipos de Ângulos}

Os ângulos são classificados de acordo com suas medidas em:

\section{Agudo}

Ângulo com medida menor que $90^{\circ}$.

Figura 5 - Ângulo agudo

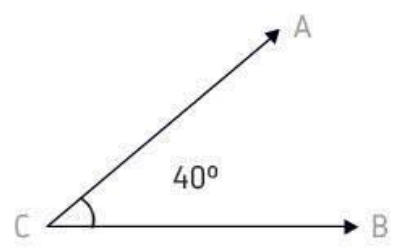

Reto 
Ângulo com medida igual a $90^{\circ}\left(=90^{\circ}\right)$.

Figura 6 - Ângulo reto

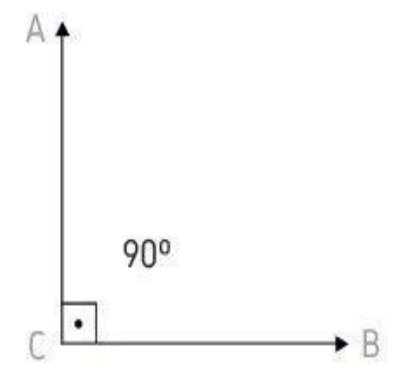

\section{Obtuso}

Ângulo com medida maior que $90^{\circ}$ e menor que $180^{\circ}$.

Figura 7 - Ângulo obtuso

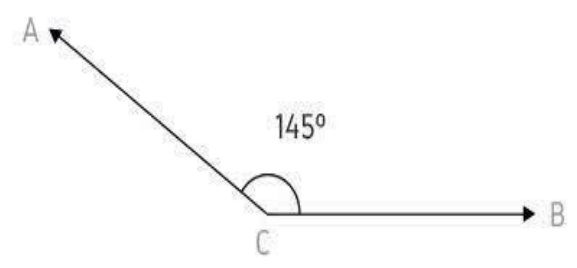

\section{Raso}

que $180^{\circ}$.

O ângulo raso, também conhecido como meia volta, mede o mesmo

Figura 8 - Ângulo raso

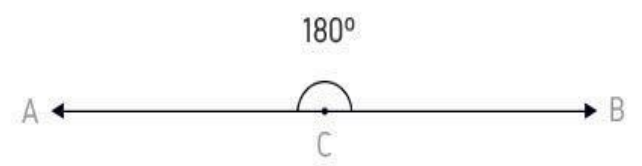

\section{Volta completa}

O ângulo volta completa mede o mesmo que $360^{\circ}$.

\section{Nulo}

O Ângulo nulo mede o mesmo que $0^{\circ}$. 


\section{SEQUÊNCIA DIDÁTICA}

Com intenção de colocar em prática os objetivos desta nova edição do PIBID 2018/2019, almejando desenvolver um trabalho que contemplasse, o máximo possível, de atividades interdisciplinar entre as licenciaturas de Letras e Matemática, como será descrita neste artigo.

De início começamos uma abordagem lendo o poema e ressaltando as figuras de linguagens que o poeta trazia e também interpretado o poema de forma minuciosa. Em seguida seguimos para abordagem sobre o conteúdo de matemática que seria trabalhando nesta sequência didática, fazendo uma conexão entre letras e matemática.

Vocabulário

1)Encontre a definição dos termos abaixo:

a)Sexagesimal:

b)Circunferência:

c) Circulo:

d) Ângulo:

2)O ângulo reto, também conhecido como ângulo de um quarto de volta, mede.
a) $90^{\circ}$
b) $180^{\circ}$
c) $270^{\circ}$
d) 360

3)O ângulo de $180^{\circ}$ é chamado de:

a) Ângulo de um quarto de volta

b) Ângulo de meia volta

c) Ângulo de três quartos de volta

d) Ângulo de uma volta

4)Considere as medidas dos ângulos, em ordem, do menor para maior, e escreva os nomes: ângulo obtuso, ângulo reto, ângulo agudo e ângulo raso.

5)O ângulo que mede menos de $90^{\circ}$ e mais de $0^{\circ}$ é chamado de:
a) Agudo
b) Raso
c) Reto 
d) Obtuso

Sobre o Texto

6)Com o seu desenho do relógio em mãos vamos pensar e concluir quanto vale cada ângulo que será feito a partir dos passo a passo.

$1^{\circ}$ Passo: Quanto vale a volta completa do relógio?

$2^{\circ}$ Passo: Divida o relógio em 12 partes iguais e quanto valera cada parte?

3 Passo: Agora com o relógio já dividido 12 partes dividam cada parte em duas, em quantas partes o relógio ficou dividido e qual é o valor de cada parte?

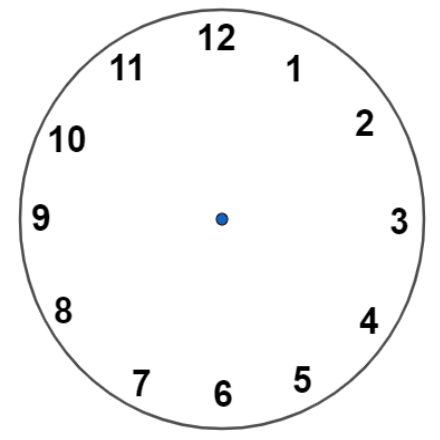

7)Estão representados vários ângulos, bem como a medida de cada um deles. Por estimativa, complete a tabela, indicando a letra que acompanha o ângulo e seu valor correspondente.

a)

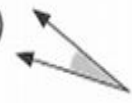

b)

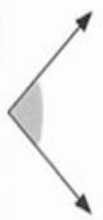

c)

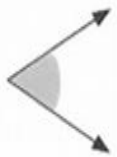

d)

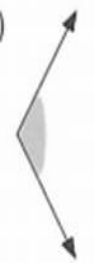

e)

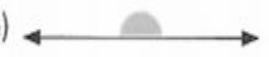

f)

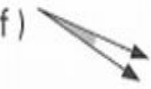


FORMAÇÃO DOCENTE: UM PROCESSO EM CONTÍNUA CONSTRUÇÃO DE CONHECIMENTOS ISBN: 978-85-5453-030-3

\begin{tabular}{||c|c|}
\hline MEDIDA & LETRA \\
\hline $60^{\circ}$ & \\
\hline $180^{\circ}$ & \\
\hline $90^{\circ}$ & \\
\hline $10^{\circ}$ & \\
\hline $20^{\circ}$ & \\
\hline $120^{\circ}$ & \\
\hline
\end{tabular}

8)Para cada alternativa vamos colocar as horas correspondentes e os ângulos que correspondem as aberturas dos ponteiros de forma que a soma dos ângulos corresponda a $360^{\circ}$ por se tratar de uma volta inteira.

a)

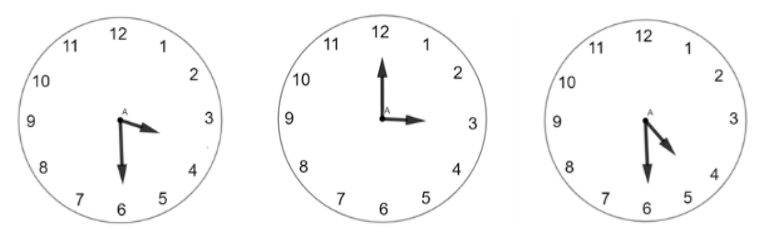

b)

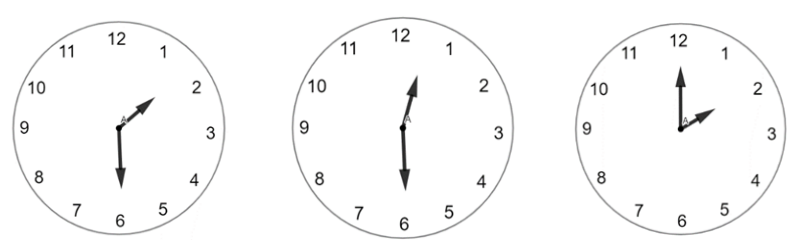

c)

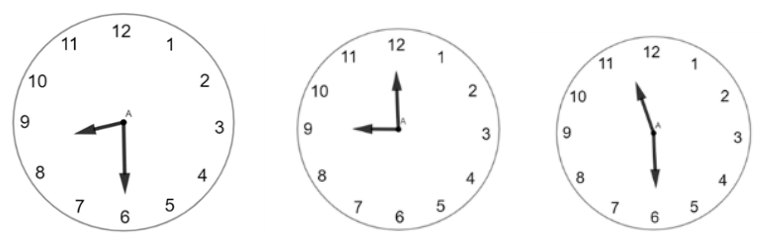

9)Às 11 horas e 15 minutos, o ângulo A formado pelos ponteiros de um relógio mede aproximadamente:
a) $120^{\circ}$
b) $112^{\circ}$
c) $108^{\circ}$
d) $127^{\circ}$ 
10)(UFMG) A diferença entre as medidas dos ângulos dos ponteiros de um relógio que marca 2 h30mim e de outro que marca $1 \mathrm{~h}$ é aproximadamente:
a) $75^{\circ}$
b) $90^{\circ}$
c) $105^{\circ}$
d) $135^{\circ}$

11) Observe os relógios a seguir:
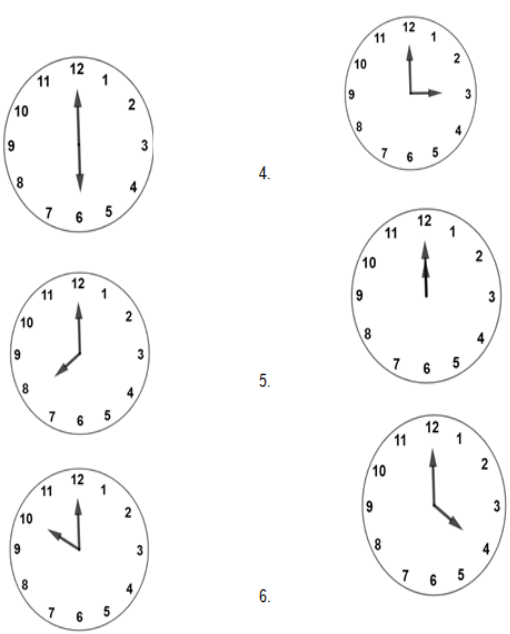

a) Quais são as medidas dos ângulos?

b) Classifique cada um deles

c) Há ângulos com medidas iguais?

d) Escreva outro horário em que os forme um ângulo reto.

12) Vamos colocar os ponteiros de modo que seu horário corresponda em cada indicação assim representar o ângulo que compete a cada abertura de seu ponteiro.

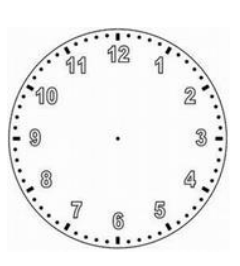

06:45

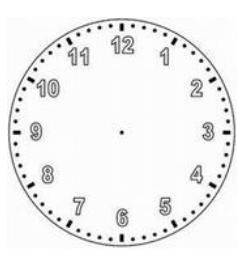

00:30

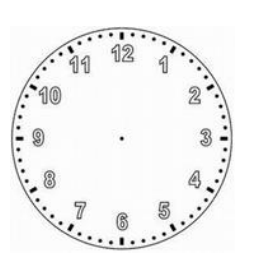

09:15

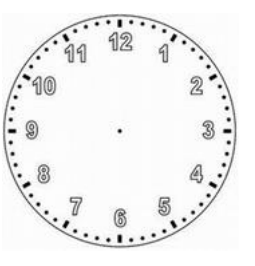

6:00

13) Vamos construir por meio da circunferência de um circulo os ângulos correspondentes:

a) Ângulo agudo

b) Ângulo reto

c) 'Ângulo obtuso 
d) Ângulo raso

Proposta de Produção

14) Agora é com você: construa um relógio com o horário preferido do seu dia, e faça um comentário, ou poema justificando o(s) por que(s) desta escolha.

\section{CONSIDERAÇÕES FINAIS}

Conforme dito anteriormente, o artigo aqui apresentado vincula-se ao Programa Institucional de Bolsas de Iniciação à Docência, PIBID/CAPES-UniFACEF, que em uma abordagem interdisciplinar, envolve os cursos de licenciaturas em Letras e Matemática, sendo desenvolvido junto aos alunos dos sextos, sétimos, oitavos e nonos ano do Ensino Fundamental II das Escolas Estaduais José Pinheiro de Lacerda e E.E. David Carneiro Ewbank da cidade de Franca-SP, com o objetivo principal de desenvolver competências e habilidades para a leitura de textos literários, bem como da linguagem matemática, uma vez que antes de se resolver uma situação-problema é imprescindível interpretá-la.

O poema de Vinicius carregado de muitas emoções e sentimento, apesar de ser um poema infanto-juvenil é rico de informações e aliado a um trabalho interdisciplinar, permite ao leitor desenvolver uma leitura crítica e reflexiva, que se materializa nas suas diferentes experiências pessoais e lhe permite ser agente desse processo de conhecimento e constante evolução que a vida oferece.

Ao aplicarmos a sequência didática desenvolvida a partir dos poemas "O relógio" e a "A casa", estabeleceu-se um elo entre as artes plásticas, na qual associou-se o poema "O relógio" à obra intitulada "A Persistência da Memória " ou " Relógios Moles", de Salvador Dali e entre, a geometria ao trabalha-se com os ângulos formados pelos ponteiros de um relógio. Dessa forma, pode-se ratificar a importância do trabalho interdisciplinar desenvolvido pelo PIBID ao apontarmos que Português, Matemática e Arte são linguagens que se inter-relacionam.

\section{REFERÊNCIAS}

DOLCE, Osvaldo; POMPEO, José Nicolau. Fundamentos de Matemática Elementar. Geometria Plana. vol. 9. São Paulo: Atual, 1995.

DOLZ, J; NOVERRAZ, M.; SCHNEUWLY, B. Sequências Didáticas para o oral e a escrita: apresentação de um procedimento. In: Gêneros orais e escritos na escola. Tradução e organização Roxane Rojo e Glais Sales Cordeiro. Campinas, SP: Mercado de Letras, 2004, p. 81 - 108.

GOLDSTEIN, Norma. Versos, sons, ritmos. 14. ed. São Paulo: Ática, 2006 
ROSA NETO, Ernesto. Didática da Matemática. 11. ed. São Paulo: Ática, 2008.

ROSENFELD, Anatol."A teoria dos gêneros". In: O teatro épico. 4. ed. São Paulo: Perspectiva, 2006.

SOARES, Angélica. Gêneros literários. 6. ed. São Paulo: Ática, 2004.

https://www.google.com/search?rlz=1C1GCEU_pt-

BRBR862BR862\&biw=1366\&bih=608\&tbm=isch\&sa=1\&ei=50ZmXZKeNdnN5OUP94e9wAU\& $q=$ linha+e+ponto+geometria\&oq=linha+e+ponto+geometria\&gs_l=img.3...7156.10130..1036 8...1.0..0.150.1361.7j6.....0....1..gws-wiz-

img.......35i39j0j0i5i30j0i8i30j0i24j0i30.8x1AAITd9_k\&ved=0ahUKEwiSoKfFtqbkAhXZJrkGHfd DD1gQ4dUDCAY\&uact=5\#imgrc=TmtdolvALvm38M:

https://escolaeducacao.com.br/

https://pt-br.facebook.com/Superinteressante/

https://mundoeducacao.bol.uol.com.br/matematica

https://exercicios.brasilescola.uol.com.br/exercicios-matematica/exercicios-sobre-

comprimento-um-arco.htm

http://files.maismatematica8.webnode.com/200000056-bfb54c1a6d/\%C3\%82NGULOS.pdf

http://files.maismatematica8.webnode.com/200000056-bfb54c1a6d/\%C3\%82NGULOS.pdf

http://portaldoprofessor.mec.gov.br/fichaTecnicaAula.html?aula=33153 


\title{
CONTRIBUIÇÕES DAS NARRATIVAS AUTOBIOGRÁFICAS SOBRE A VIDA NA INFÂNCIA EM CONTEXTO DE FORMAÇÃO LÚDICA DE PROFESSORES
}

\author{
SOMMERHALDER, Aline \\ Docente - UFSCar \\ OLIVEIRA, Carla de \\ Mestre UFSCar \\ SILVA, Deise Aparecida \\ Doutoranda - UFSCar \\ deisesmalta@hotmail.com
}

\section{1) INTRODUÇÃO}

Esse texto resulta de uma pesquisa concluída realizada em um projeto de extensão universitária de uma Universidade Pública, intitulado "Formação Lúdica de Professores: construindo saberes e fazeres da prática pedagógica”. A presente ação de extensão caracterizou-se como uma formação continuada para professores/as da Pedagogia que atuam na Educação Infantil e/ou nos Anos Iniciais do Ensino Fundamental de São Carlos/SP e/ou região (rede municipal de São Carlos e/ou região, rede estadual de ensino de São Paulo e rede particular de ensino de São Carlos e/ou região) e de formação inicial para estudantes dos cursos de Pedagogia modalidade presencial e a distância e de Licenciatura em Educação Física.

O objetivo da "Formação Lúdica" está em possibilitar, a partir de uma prática de extensão universitária, um espaço para discussões, reflexões e construções de conhecimentos teóricos e práticos relacionados ao lúdico nas práticas pedagógicas com crianças, focalizando a formação lúdica de professores.

Reconhece-se que as práticas pedagógicas para crianças devem incorporar o lúdico no cotidiano. Para tanto, um ponto central de discussão assentase sobre a formação de professores, para essa ludicidade, valorizando nessa formação a dimensão pessoal do ser professor, com sua trajetória de vida, histórias e percursos lúdicos vividos.

Evidenciando a importância da formação lúdica de professores e reconhecendo essa ação de extensão enquanto espaço privilegiado para estudo, troca de experiências, saberes e conhecimentos sobre a temática e que corrobora com oportunidades de aprendizagem para os/as profissionais que atuam ou irão atuar na docência com crianças, esse texto objetiva descrever e evidenciar aprendizagens contributivas para a formação de professores, adotando como 
metodologia memórias - recordações de vida lúdica na infância de professoras participantes de uma ação de formação, em nível de extensão universitária.

\section{EXTENSÃO UNIVERSITÁRIA COMO POSSIBILIDADE DE FORMAÇÃO DE PROFESSORES}

A ludicidade na formação do educador da infância se faz necessária tanto no âmbito teórico, pois traz respaldo sobre a importância dos jogos e brincadeira, quanto no âmbito da prática, pois através da lucididade, o/a professor/a oportuniza condições para melhor conhecer a criança, por meio dos jogos e brincadeiras (SANTOS, 2000).

Para a autora, é de ampla importância que a formação inicial de professores, e podemos estender para a formação continuada tenha em seus currículos, o estudo do lúdico e das implicações dessa linguagem no desenvolvimento e aprendizagem das crianças. Na formação para a docência, o estudo de jogos e brincadeiras assim como de outras linguagens lúdicas, como as artes e a literatura infantil são de grande relevância para a formação do professor/a de infância.

Kramer (1999) assinala que:

As pessoas que trabalham diretamente com as crianças precisam estar continuamente se formando, para exercer sua função da melhor maneira possível, de forma a favorecer o desenvolvimento infantil em diversos aspectos, promovendo a ampliação das experiências das crianças e de seus conhecimentos. (KRAMER, 1999, p.78).

Do mesmo modo, Santos (2000) aponta que o docente deve ser ativo, dinâmico, curioso, reflexivo, inovador e produtor, conhecedor do universo infantil. Nessa perspectiva, para trabalhar com jogos e brincadeiras e outras linguagens lúdicas é preciso conhecimento aprofundado que incluí, ainda, o estudo sobre o desenvolvimento e aprendizagem infantil.

No jogo compartilhado com a criança, acolher as fantasias, provocar o despertar da criatividade e do desejo de saber. Não se trata simplesmente de sugerir uma brincadeira ou deixar que as crianças brinquem livremente, mas de 'brincar com', de compartilhar com as crianças suas produções, de criar espaços para que possam atribuir significados a estas produções e também apropriar-se da cultura lúdica. Ao compartilhar as brincadeiras com a criança, o professor compartilha também das fantasias colocadas em cena pelas crianças, sem contar suas próprias fantasias (infantis). (ALVES; SOMMERHALDER, 2011, p.55).

O/a professor/a da infância auxilia, amplia e valoriza o repertório de brincadeiras e jogos para a criança, sendo responsável pela mediação da linguagem 
lúdica, selecionando ainda objetos lúdicos de qualidade, proporcionando tempo vasto e espaços interessantes, ludicamente, para a criança. O acompanhamento do brincar infantil, a observação da criança brincando, brincar junto com elas, o incentivo de novas formas de brincar e a apresentação de novas brincadeiras e jogos são ainda qualidades fundamentais para a docência com crianças.

Alves e Sommerhalder (2011, p. 56) apontam que:

Aproximar seus interesses didático-pedagógicos com os interesses das crianças pode resultar numa aula mais rica e significativa em termos de aprendizagem. Além disso, é importante que o professor conheça os contextos culturais de cada criança, a fim de acolher as experiências lúdicas vivenciadas por elas nestes diversos contextos, procurando sempre ampliálas. Isso significa que procurar saber de que brincadeiras ou jogos as crianças gostam e vivenciam pode enriquecer o processo de ensinoaprendizagem. (p. 56).

Portanto, vale ressaltar que o trabalho pedagógico com jogos e brincadeiras para as crianças oportuniza um processo de ensino e de aprendizagem mais envolvente, interessante e curioso em relação ao conhecimento a ser descoberto. Nesse sentido, damos alguns passos no que se refere a pensar e fazer uma educação de qualidade e que atenda às necessidades da criança, respeitandoa em suas especificidades. Para que isso ocorra, é preciso que as práticas lúdicas sejam planejadas como parte do currículo e que esta linguagem se faça adequadamente estudada na formação de professores, visando também a concretização de uma formação lúdica de professores, na perspectiva de uma educação para a humanização da criança.

Abordar a formação de professores compreende entendê-la primeiramente na perspectiva de Mizukami (2010, p.13): "um continuum, ou seja, um processo de desenvolvimento para a vida toda". Dassoler e Lima (2012) também apontam que a formação vai além de um curso inicial, constituindo um processo que acontece ao longo da vida.

O conceito de formação é geralmente associado a uma atividade, ou seja, formar-se para algo. Nesse contexto, a formação de professores pode ser entendida como a função social de transmissão de saberes, de saber-fazer ou do saber-ser em benefício do sistema socioeconômico ou da cultura dominante. (MARCELO GARCÍA, 1999, p. 19).

Alvorada-Prada et al. (2003) afirmam que o conceito de formar-se é vindouro para a vida toda, uma vez que o ser humano possui oportunidades para aprendizagem, humanizando-se, por meio de relações, interações e mediações com o mundo e com o meio em que habita, em seus diversos espaços. Assim, aprender vai além de obter e receber conhecimentos, sendo um processo de compreensão e conhecimento de novas aprendizagens. Alvorada-Prada et al. (2003, p. 371) destacam: "formar-se é um processo de aprendizagem", que permeia toda a vida do indivíduo e este para de aprender quando encerra seu ciclo vital, ou seja, sua morte. 
Nessa perspectiva, Freire (2011) enfatiza que educar não é apenas transferir conhecimentos, mas sim a conscientização de vida, ou seja, a consciência de inacabamento, ser inconcluso, sendo um templo de possibilidades e construções. Por isso, os processos formativos permanecem ao longo da vida das pessoas e estas estão em constante aprendizagem.

É fundamental repensar o papel social e cultural do professor, redefinindo sua formação para que não permaneça focalizada somente no domínio de conteúdos, metodologias, critérios de avaliação ou gestão competente de recursos, mas que seja capaz de adotar uma nova concepção de educação e formação, percebendo o educador como sujeito sociocultural e a educação como parte constituinte do processo de humanização, socialização e formação para viver a vida.

Nesse contexto, elencamos a extensão universitária como possibilidade formativa, entendendo que a formação, a partir dessa atividade, vai além do estudo dos conteúdos sistematizados que as disciplinas escolares esperam, mas contempla a aproximação entre teoria e prática, na relação entre saberes da experiência e saberes científicos, possibilitando processos de reflexão sobre, identidade, docência e prática pedagógica (MARCELO GARCÍA, 1999).

A formação, a partir da extensão universitária, assume um papel capaz de transcender o ensino que visa atualizar cientificamente, pedagogicamente e didaticamente os professores, transformando-se em espaço para criações, invenções e experimentos de vivências, permitindo que os educandos reflitam sobre as aprendizagens e conhecimentos, buscando autonomia pessoal e profissional (IMBERNÓN, 2009).

\section{PROCEDIMENTOS METODOLÓGICOS}

A presente pesquisa, que origina esse material, foi realizada na qualitativa (MINAYO, 2010). A pesquisa de campo contemplou um estudo de natureza descritiva e exploratória que, segundo Gomes (1999) valoriza as falas e os pensamentos dos sujeitos, devendo ser considerados fielmente. Somado a isso, trata-se de uma pesquisa realizada com e não sobre as pessoas.

A pesquisa foi inspirada ainda na abordagem de histórias de vida (SOUZA, 2006), assim, partiu-se da consideração do método biográfico, como um método educativo, utilizando-se como instrumento de coleta de dados a narrativa formativa (oral e escrita).

Caracterizada ainda como um estudo de caso (YIN, 1984) foi realizada em um contexto específico, com modelagem, temáticas, tempo de duração e público alvo definidos a partir dos objetivos de um Projeto de Extensão Universitária, com devida aprovação da Universidade Federal envolvida. 
A extensão universitária "Formação Lúdica de Professores: construindo saberes e fazeres da prática pedagógica", aprovada pela Pró-reitoria de Extensãoprocesso ProEx n. 23112.000815/2017-83 contou com um cronograma de 8 encontros presenciais (durante o segundo semestre de 2016 - de agosto a dezembro) e foi realizada em uma Universidade Federal, quinzenalmente, às terças feiras, no horário das $14 \mathrm{~h} 30$ às $16 \mathrm{~h} 30$.

Cabe dizer que as atividades solicitadas para a coleta de dados já estavam programadas para serem desenvolvidas na ação extensionista fazendo essas, parte da programação de todas as ofertas deste Projeto.

O grupo participante da ação de extensão foi composto por 25 participantes, sendo: 17 professoras da rede pública municipal de ensino, 1 docente da rede pública de ensino de outro município da oferta do Projeto, que atua na educação do campo e 1 docente que atua no cargo de coordenadora pedagógica de uma instituição particular de ensino. Em relação aos estudantes do curso de Pedagogia, contávamos com a presença de 4 estudantes de universidade federal e 2 discentes de uma instituição particular de ensino superior, também do município do interior do estado de São Paulo.

Foram selecionadas 5 participantes que fizeram a composição dos sujeitos da pesquisa. Foi considerado como aspecto para definir como sujeitos da pesquisa as participantes que entregaram todas as narrativas escritas e que 0 conteúdo das mesmas não fosse apenas descritiva, mas que contemplasse reflexões acerca do brincar, de suas lembranças do tempo da infância e as aprendizagens adquiridas nessa história de vida. Além disso, considerou-se também a participação nas rodas de conversa, ou seja, a participação nas narrativas orais, refletindo, debatendo, expondo memórias e situações vividas em seus cotidianos e não apenas participações com gestos como, por exemplo, balançar a cabeça em concordância ou negativa e/ou somente a presença física nos encontros.

Esses cinco sujeitos do estudo são caracterizadas como: 3 professoras da rede pública de ensino., sendo 2 docentes atuantes na educação infantil, 1 docente em exercício no primeiro ano do ensino fundamental e 2 estudantes do curso de Pedagogia. Sobre a estudante do curso de Licenciatura em Pedagogia, a mesma encontra-se cursando o $4^{\circ}$ ano da graduação em uma Universidade Federal, sendo sua primeira graduação. A outra estudante realiza o curso em uma instituição particular e está em seu último ano de graduação.

As participantes foram informadas sobre a aprovação da pesquisa pelo Comitê de Ética em Pesquisa com Seres Humanos (CEP), sob n. de parecer de aprovação: 1.680 .413 e houve a entrega e leitura, com esclarecimentos do Termo de Consentimento Livre e Esclarecido - TCLE, assinado pelas mesmas.

Tivemos como instrumentos utilizados para a coleta de dados da pesquisa de campo as narrativas escritas e rodas de conversa temáticas, essas últimas compostas por narrativas orais. Foram produzidas 4 narrativas escritas com 
temas referentes ao brincar, a infância, e formação pessoal e profissional, tomando como eixo comum as lembranças brincantes ou de brincadeiras/jogos vividos em percurso de infância e realizadas e incorporadas, na pesquisa, 4 rodas de conversa temáticas. Sobre as rodas de conversa, cada uma foi filmada com imagem e som e teve duração aproximada de trinta (30) minutos. As filmagens foram transcritas na íntegra, buscando capturar não somente os diálogos, falas, mas ainda expressões e gestos.

Nesse sentido, os dados foram coletados por meio de escritas autobiográficas (narrativas escritas e orais provenientes das rodas de conversas, que ocorreram ao longo do processo- atividade de formação e não somente uma produção). Em essência, os temas para as narrativas versaram sobre conteúdos provenientes de lembranças da infância e enfatizaram jogos, brincadeiras e brinquedos vividos em período de infância, reconhecendo as experiências pessoais e a influência dessas memórias na formação e na aprendizagem para a docência com crianças.

A organização, análise e compreensão dos dados foram realizadas à luz do referencial teórico escolhido. Para esse texto, apresentamos os resultados do eixo temático: Brincar e a formação.

\section{RESULTADOS E DISCUSSÃO}

Neste item, apresentamos uma parte dos resultados, enfatizando aqueles referentes ao "Brincar e a formação". As narrativas das participantes da pesquisa trouxeram episódios marcantes de experiências vividas e escolhas realizadas, com aspectos que inspiram reflexões e contributos para a formação docente. Alguns depoimentos trouxeram o brincar como prática central para a criança e enfatizaram como esta experiência de vida auxiliou na formação para ser professor e na construção das identidades.

As brincadeiras, os jogos e os brinquedos conheci na minha infância, tive a contribuição do brincar, o aprendizado com essas atividades, realizadas, ás vezes com ajuda, com amigos e outras vezes sozinha mesmo e ao longo do caminho fui construindo minha personalidade, fazendo minhas escolhas e aqui estou!. (Renata estudante de graduação, licenciatura em Pedagogia; 3ํㅡarrativa escrita).

O brincar me tornou a pessoa que sou hoje, com os meus valores, minhas qualidades e também meus defeitos, foi através da brincadeira que consegui entender minimamente a complexidade das relações humanas e sociais. Por isso, quis tanto fazer o curso, pois brincar é algo muito importante que reflete imensamente o "quem" seremos no futuro e como trataremos vários aspectos da nossa vida. (Laura professora em exercício docente; $3^{\circ}$ narrativa escrita).

Os relatos de Renata e Laura nos convidam a pensar sobre a relação entre o brincar e as suas contribuições para a formação dos professores. 
Comumente, há o discurso circulante de que o brincar é importante para o desenvolvimento infantil, porém as lembranças dos prazeres da brincadeira vão se recolhendo nas memórias e a vida adulta abrindo espaço para outros prazeres.

Ao exercer a docência, os professores são dotados de cobranças pedagógicas, fazendo com que, muitas vezes, o brincar não encontre mais espaço no cotidiano das práticas pedagógicas com as crianças. Isso ocorre até mesmo nos cursos de formação de professores, que estão tão focados em teorias e conteúdos sistematizados, e acabam deixando para o conhecimento do lúdico um pequeno ou inexistente espaço (IMBERNON, 2009).

Os relatos de Renata e Laura revelaram que o brincar propiciou experiências ricas para além do desenvolvimento da criança, ou seja, experiências com aprendizagens para a vida e para a construção de sua identidade. Assim, o que se vive na infância e em todo o trajeto de vida do ser humano auxilia na formação da identidade do sujeito, na sua construção enquanto pessoa e no ser profissional (NÓVOA, 2013).

A participante Rosa apontou que, por meio do brincar, passou a se conhecer, se compreender, fomentando a aprendizagem por meio dessa vivência, sendo o brincar impactante em sua formação humana e profissional.

Enfim, penso que o tempo do brincar foi o período de maior aprendizagem, e mais, aprendi com mais intensidade de mim mesma (do meu SER), sem cobrar de mim mesma uma aprendizagem. Não exigia de mim mesma uma aprendizagem, ia aprendendo. (Rosa professora em exercício docente; $3^{\circ}$ narrativa escrita).

O professor possui um papel fundamental na vida de seus alunos, pois no contexto escolar permite explorar e conhecer um mundo distinto do vivido em casa, no bairro, sendo a escola um local de maior convívio com a diversidade de pessoas, de pensamentos, de culturas e histórias de vida. O brincar, nesse contexto, auxilia a criança a encontrar subsídios de compreensão e entendimento do que vivência. Dessa forma, ao rememorar o brincar na infância, e as situações vividas, o docente reencontra em suas lembranças imagens que possibilita sua formação e imagens de práticas docentes de seus professores que lhes marcam, servindo de exemplos (PASSOS, 2003).

Sem dúvida, essas experiências vividas nas infâncias são colaborativas como oportunidades de reflexão e atribuição de novos significados, para quem exercerá ou exerce a docência com crianças. Colocar luz sobre essas lembranças ajuda a repensar acerca dos interesses infantis, dos prazeres desse período da vida e da promoção de um processo educativo (de ensinar e de aprender) com mais significado para as crianças.

Na visão de Renata, as brincadeiras, jogos e brinquedos, não foram os únicos meios que influenciaram nas escolhas para a docência, sendo explorado em sua narrativa o contexto além da escola, como as vivências na vida pessoal e dos momentos vividos além do brincar: 


\begin{abstract}
Assim, tenho as memórias das brincadeiras, lá na infância, mas não concordo que é o único motivo que me influenciou na minha formação docente. Acredito numa combinação das lembranças, das escolhas que vamos fazendo ao longo da nossa caminhada e a empatia com a escola, o ensinar, com o prazer em promover conhecimento. Na questão colocada, acredito ainda que o brincar estabeleceu diversas habilidades $e$ características a minha personalidade, não somente focando à docência (a vida profissional) como também a minha vida pessoal. As escolhas que fiz, e que são feitas ao longo da vida, acho que são reflexos dos momentos vividos e a infância, é um destes momentos. (Renata estudante de graduação, licenciatura em Pedagogia; 4ํㅡㅁ narrativa escrita).
\end{abstract}

Renata enfatiza que as pessoas são construídas pelas experiências, ou seja, não defende o brincar como o único propulsor de formação humana, mas aponta o que viveu como uma vantajosa ferramenta formativa.

As experiências adquiridas ao longo da vida permitem que o ser humano se forme, se constitua de lembranças que contribuem para sua formação profissional, e o brincar permite que a criança explore o mundo, conhecendo-o.

Nessa direção, Tonucci (2005) chama atenção para necessidade de 0 adulto reconhecer a essencialidade em que a criança possui por espaços e tempos para brincar, construindo e reconstruindo-o, oportunizando momentos e situações corriqueiras que permitem essa prática social.

Brincar é o espaço e o momento em que há entrega de corpos, se movimentando nas ações, criando e recriando novos estilos de brincar, com o outro, consigo mesmo, com os objetos. Brincar ocupa um forte e elevado espaço na vida da criança. Por meio do brincar, a criança experimenta e vivencia situações do mundo que marcam sua trajetória de vida e suas escolhas, dessa forma alimentando o ser professor, que revive o sabor da infância com seus alunos.

Freire (2014, p. 29) elucida que:

A atividade de brincar, jogar, rir com as situações de aprendizagens são instrumentalizadas pelo exercício da reflexão cotidiana sobre a prática. Rimos quando já ganhamos certo distanciamento do objeto em estudo. No envolvimento dos desafios "não tem graça nenhuma"...É na reflexão sistematizada sobre a prática que conquistamos esse distanciamento necessário para vermos nossos erros e acertos, ou de podermos alimentar nosso brincar. Rimos porque a reflexão nos mostra o processo. Processo constituído de avanços e recuos, onde sempre o desafio é crescer, mudar, transformar. É, neste sentido, que a reflexão alimenta nossa capacidade de rir e brincar, pois podemos constatar que estamos a serviço da esperança, da vida.

Educador que ri e brinca na construção de sua aula favorece a desmistificação do modelo teórico e sua relação quanto a autoridade. Humaniza-se enquanto modelo na medida em que trabalha seus erros, convidando os outros a rirem deles.

O riso presente na infância, também se faz necessário no âmbito profissional. Ou seja, rememorar as lembranças de infância, permite que o educador relembre o que viveu, desencadeando um processo de reflexão e de nova 
significação sobre o vivido (sobre crenças, representações, ideias e concepções). Resignificar esse vivido é fundamental para uma melhor consciência de suas ações docentes com as crianças, compreendendo que algumas automatizações de ações estão relacionadas a estas marcas do vivido, em tempos de infância.

\begin{abstract}
Percebo as vivências consideradas negativas na escola em contraponto com as agradáveis que ocorriam nas brincadeiras de interação constante com a natureza e com outras crianças, consolidaram em minha personalidade-identidade à vontade e o desejo de propiciar as crianças uma escola e uma vida mais progressista, mais alegre e prazerosa. (Rosa professora em exercício docente; $4^{\circ}$ narrativa escrita).
\end{abstract}

Na narrativa de Rosa, há uma importante passagem no que se refere a transformação da educação para as crianças, em um processo prazeroso e agradável, uma vez que em sua vivencia formativa no contexto escolar, os momentos alegres foram escassos.

Freire (2014, p. 30) ensina:

Educador que brinca e ri enquanto ensina favorece o lidar com a tensão que todo o processo de aprendizagem contém. $O$ riso dosa o confronto com esta, amenizando a ansiedade e o mal-estar.

Para rir e brincar construindo conhecimento é necessário uma boa dose de humildade e abertura para as divergências, as diferenças. Também disponibilidade para conviver com o estado de desarmonia que o conflito provoca.

Para rir e brincar com o próprio processo de aprendizagem e dos demais necessitamos alimentar nossa curiosidade, juntamente com nossa ansiedade para conhecer o novo, o inusitado.

Para rir e brincar, enquanto aprendemos e ensinamos, é necessário querer bem. Acreditar que o outro é (sempre) capaz de aprender, onde o riso e a alegria são instrumentais exercitados no jogo de sua aprendizagem.

A partir do que Rosa narrou, podemos compreender que nossas experiências alimentam a construção da identidade, sendo importante refletir sobre essas vivências e o que podemos obter de aprendizagens para o exercício da docência com crianças.

Sobre isso, Oliveira (2008) aponta que "o mundo começa na infância e será conhecido pela criança de acordo com a experiência vivida por ela" (OLIVEIRA, 2008, s/p), assim, entende-se que as vivências os formam e os constroem, sendo por meio do brincar a chave de expressão e comunicação da criança.

De tal modo, a formação de professores também é composta pelo que o docente carrega em sua bagagem de vida, ou seja, os saberes da experiência. $O$ mergulho na infância, a rememoração do que viveu, permite entender escolhas e decisões, caminhos seguidos e representações arquitetadas.

A relação entre o vivido na infância e formação de professores é algo intrínseco, ou seja, Bueno (2002) assinala que o adulto em sua realidade presente, possui percepções de lembranças de seu passado que permite o repensar e refletir 
o seu futuro, desencadeado através de um processo em que a própria pessoa se forma em seu percurso de vida.

Para isso é fundamental que a formação, seja essa inicial ou continuada, considere esse profissional em formação enquanto pessoa, dotado de experiências, que sente, pensa, fala, cria, recria, altera, modifica e que se encontra em constante aprendizagem (NÓVOA, 2014).

\section{CONSIDERAÇÕES FINAIS}

A partir desta pesquisa, consideramos que as experiências pessoais nutrem o ser professor, enfatizando a importância da valorização dessas experiências em processos de formação de professores.

Ao narrar, de forma escrita ou oral, as professoras participantes dessa pesquisa compartilharam suas lembranças de infância brincante, sendo essas colaborativas no processo de formação. Essas recordações, quando conhecidas e refletidas, operam nas escolhas profissionais e desenvolvimento profissional.

A formação de professores é um processo contínuo e inacabado, uma vez que o ser humano se encontra em formação e construção ao longo da vida. Essa formação vai além de dominar os conteúdos escolares, é uma aprendizagem que envolve também saberes das experiências, gerados em processos de socialização, em diversos espaços vividos em sua trajetória de vida. As aprendizagens adquiridas ao longo da infância brincante oportunizam reflexões e novos significados sobre a educação das crianças e o desenvolvimento profissional das participantes.

A Extensão Universitária é um espaço de destaque para a formação contínua de professores, pois promove a relação entre teoria e prática e a socialização de conhecimentos científicos para a sociedade, por meio das parcerias entre universidade e comunidade. Compreendemos que é uma tarefa da universidade dialogar com a sociedade, buscando responder suas demandas e expectativas, efetivando uma relação de compartilhamento entre conhecimentos acadêmicos e saberes da experiência, visando um processo de transformação social.

\section{REFERÊNCIAS}

ALVARADO-PRADA, L. E.; ROSA, R. M.; OLIVEIRA, V. F. A formação continuada de professores e a caracterização da comunidade escolar: os pais. In: Encontro de pesquisas em educação do Centro Oeste, 6., 2003, Campo Grande. Resumos... Campo Grande: ANPED, 2003. 
FORMAÇÃO DOCENTE: UM PROCESSO EM CONTÍNUA CONSTRUÇÃO DE CONHECIMENTOS ISBN: 978-85-5453-030-3

BUENO, Belmira Oliveira. O método autobiográfico e os estudos com histórias de vida de professores: a questão da subjetividade. Educação e Pesquisa, São Paulo, v. 28, n.1, p.11-30, jan/jun. 2002.

BROUGÈRE, Gilles. Brinquedo e Cultura. São Paulo: Cortez, 2010.

DASSOLER, Olmira Bernadete; LIMA, Denise Maria Soares. A formação e a profissionalização docente: características, ousadia e saberes. ANAIS IX Anped Sul. Seminário de Pesquisa em Educação da região Sul, 2012, p. 1-11.

FRANCO, Maria Laura Publisi Barbosa. Análise de conteúdo. Brasília: Liber Livro, 2012.

FREIRE, Madalena. Educador. São Paulo: Paz e Terra, 2014.

GARCIA, Carlos Marcelo. Formação de Professores: para uma mudança educativa. Porto- Portugal: Porto Editora, 1999.

GOMES, Romeu. A análise de dados em pesquisa qualitativa. In: Minayo, M. C. S.(Org.) Pesquisa Social: Teoria, Método e Criatividade. Ed. Vozes; Petrópolis, 1999, p.67-80.

IMBERNÓN, Francisco. Formação docente e profissional: formar-se para a mudança e a incerteza. São Paulo: Cortez, 2009.

KRAMER, Sônia. Infância e educação: O necessário caminho de trabalhar contra a barbárie. In: KRAMER, Sônia; LEITE, Maria I.; NUNES, Maria F.; GUIMARÃES, Daniela (orgs). Infância e educação infantil. Campinas: Papirus, 1999.

MINAYO, Maria Cecília de Souza (org.). Pesquisa social: teoria, método e criatividade. 29. ed. Petrópolis, RJ: Vozes, 2010.

MIZUKAMI, Maria da Graça Nicoletti, et al. Escola e aprendizagem da docência: processos de investigação e formação. São Carlos: EdUFSCar, 2010.

NÓVOA, António. Os professores e as histórias da sua vida. In: NÓVOA, António (organização). Vida de professores. Portugal. Porto Editora, 2013, p. 11-30.

NÓVOA, António. O passado e o presente dos professores. In: NÓVOA, António (organização). Profissão Professor. Porto Editora, 2014, p.13-34.

OLIVEIRA, Mara Conceição Vieira de. Manoel de Barros: infância, imagem e conhecimento. XI Congresso Internacional da ABRALIC Tessituras, Interações, Convergências 13 a 17 de julho de 2008 USP - São Paulo, Brasil.

PASSOS, Mailsa Carla. Memória e história de professores: como práticas também é lembrar. IN: VASCONCELOS, Geni A. Nader (org.). Como me fiz professora. - Rio de Janeiro: DP \&A, 2003, 2. Ed. p. 99-112. 
FORMAÇÃO DOCENTE: UM PROCESSO EM CONTÍNUA CONSTRUÇÃO DE CONHECIMENTOS ISBN: 978-85-5453-030-3

SANTOS, Santa Marli Pires dos. Brinquedoteca: a criança, o adulto e o lúdico. 4ª ed. Petrópolis: Editora Vozes, 2000.

SOMMERHALDER, Aline; ALVES, Fernando Donizete. Jogo e a educação da infância: muito prazer em aprender. Curitiba, PR: CRV, 2011.

SOUZA, Elizeu Clementino de. O conhecimento de si: estágio e narrativas de formação de professores. Rio de Janeiro: DP\&A; Salvador, BA: UNEB, 2006.

TONUCCI, F. Quando as crianças dizem: agora chega! Porto Alegre: Artmed, 2005.

YIN, Robert K. Estudo de Caso: planejamento e métodos. São Paulo: Bookman, 1984. 


\title{
EDUCAÇÃO, PESQUISA E DESENVOLVIMENTO: O passado que repercute no presente e as tendências rumo ao humanismo
}

\author{
GUERRA, Sandra Aparecida Ferreira \\ Mestre em Desenvolvimento Regional - Uni-FACEF \\ saferrei@hotmail.com \\ OLIVEIRA, Sheila Fernandes Pimenta e \\ Doutora em Língua Portuguesa e Linguística - UNESP \\ sheilafacef@gmil.com \\ GUERRA, José Alfredo de Pádua \\ Doutor em Serviço Social - UNESP \\ josealfredopaduaguerra@gmail.com
}

\section{INTRODUÇÃO}

Em uma sociedade capitalista, os procedimentos educacionais contemporâneos são frutos das transformações econômicas, políticas, tecnológicas, científicas e probabilidades de desenvolvimento social. Consequentemente, a educação pode ser uma demonstração de resposta a essas transformações, e precisa ser considerada, a partir de um "estudo" histórico, uma vez que muito do que se faz atualmente nas escolas apresenta ascendência em teorias pedagógicas clássicas ignoradas pelos próprios educadores.

De acordo com Leontiev (1978), desde os primórdios da humanidade, existia a preocupação em conhecer o mundo natural e social. Sem dúvida, a preocupação continua na realidade cultural e social da atualidade. Para o autor, o tempo humano deve ser compreendido como história concreta, como processo de desenvolvimento do homem e da sociedade, que se efetiva na atividade produtiva, criadora e transformadora, realizada por cada sujeito social. Ou seja, a cada tempo histórico, num espaço de mundo determinado, acontecia a pesquisa e a busca constante pelo conhecimento, por meio de diferentes métodos e técnicas.

O conhecimento do mundo natural e social é lento, gradativo, em que o ser humano utiliza a razão, de forma inteligente e astuta para sua compreensão. Assim, a pesquisa em e na Educação exerce um papel predominante, para que se possa conhecer a realidade histórica, social e educacional. Para Freire (2007), é na relação com o outro que o ser humano aprendeu e aprende todos os dias a ser o que é, como inteligência ou personalidade, que constitui a fonte da consciência e a compreensão do processo de desenvolvimento. 
Nesse contexto, o presente artigo, realizado por meio de pesquisas bibliográfica e histórica, objetiva tratar o lugar da educação contemporânea e a relação com os desenvolvimentos humano e social, numa abordagem que leve em conta a complexidade inerente ao conceito, buscando possibilidades de reflexão nas bases históricas e teóricas do pensamento desenvolvimentista, sob o olhar diferenciado para o mundo e nas variáveis envolvidas. Uma proposta de educação que seja centrada na problematização, através da pesquisa, ou seja, uma ideia de ensino centrada no estudante, tendo o professor como parceiro mediador, que desperte a curiosidade e a reflexão dos educandos para a busca e construção do seu próprio conhecimento.

\title{
2. UM OLHAR DIFERENCIADO PARA O MUNDO: o predomínio do racionalismo
}

O ponto central das discussões é o diálogo da educação com as formas de desenvolvimento que promovam resultados positivos para o homem e a sociedade, de forma refletida e exequível.

Uma perspectiva para redução das desigualdades sociais pela educação transformadora, libertadora e não apenas visando às questões econômicas:

\begin{abstract}
Uma concepção adequada de desenvolvimento pode ir muito além da acumulação de riquezas e do crescimento econômico do produto Nacional Bruto e de outras variáveis relacionadas à renda. Sem desconsiderar a importância do crescimento econômico, precisamos enxergar muito além dele (SEN, 2012, p. 28).
\end{abstract}

No contexto, Oliveira (2010) relata que autores como Robert Nisbet (1969) e John Bury (1955), estudiosos que trabalharam a construção histórica e sociológica da noção de desenvolvimento da sociedade humana, buscaram, na história antiga, as bases constitutivas do pensamento desenvolvimentista, ressaltando a relevância dos gregos e da sociedade cristã para a construção da ideia de progresso das civilizações. Assim, uma ideia que aparece, de maneira considerável nos séculos XVII e XVIII, no contexto iluminista, tornando-se base fundamental do pensamento moderno e uma das principais bases de sustentação da noção de desenvolvimento:

Robert Nisbet (1969) entende que a noção de desenvolvimento não deve ser encarada como um conceito rígido, passível de ser provado e explicado por meio da racionalidade científica, mas sim como uma metáfora. Muitas das concepções de mundo são criadas a partir de imagens e entendimentos que muitas vezes são sintetizadas por meio de metáforas, e nesse sentido, a metáfora do "desenvolvimento" é uma das mais poderosas no pensamento ocidental, responsável por consolidar uma estrutura de pensamento que, em certa medida, perpassou os povos gregos, a sociedade cristã e culminou como base de formação do mundo moderno (OLIVEIRA, 2010, p. 50). 
A ideia de progresso, no lluminismo, obteve impulso e passou a ser algo natural, uma tendência intrínseca à vida humana. Foi, no século das luzes, que a ciência e a razão se tornaram princípios do avanço da humanidade, por meio destas, o homem poderia ser livre e evoluir. A definição de lluminismo, por Kant, ressalta o ideal disseminado na época:

lluminismo é a saída do homem da sua menoridade de que ele próprio é culpado. A menoridade é a incapacidade de se servir do entendimento sem a orientação de outrem. Tal menoridade é por culpa própria, se a sua causa não residir na carência de entendimento, mas na falta de decisão e de coragem em se servir de si mesmo, sem a guia de outrem. Sapere aude! Tem a coragem de te servires do teu próprio entendimento! Eis a palavra de ordem do lluminismo (KANT, 1990, p. 516).

Para Oliveira (2010), os pensadores que participaram do movimento consideravam que sua época carecia da luz da razão, ou seja, a natureza e a sociedade eram compreendidas por meio da racionalidade. Assim, as ideias iluministas tiveram consequências significantes nos movimentos sociais, por todo o mundo, favorecendo o fortalecimento dos valores da burguesia, classe social crescente ao poder econômico e político do século XVIII. Todorov (2008) relata que o iluminismo absorve e articula opiniões que no passado estavam em conflito, sendo assim uma época tanto racionalista quanto empirista, herdeira tanto de Descartes como de Locke. Esse impasse é o que caracteriza o iluminismo:

O século XVIII é cartesiano e prossegue a grande revolução intelectual do mestre, extraindo as consequências dos princípios que este apresentou, não sem transformar, por vezes, o pensamento do filósofo, cujo conjunto não apreendia. Guarda-se de Descartes, principalmente, o que este tinha em comum com os mecanicistas do seu tempo. É corrente a afirmação de que o reinado de Descartes cessa por essa altura, substituído pelo de Locke e Newton (TERMAS, 2000, p. 350).

Com essa revolução de pensamentos racionais, o método cartesiano, o empirismo, foram pontos de partida para a modernidade, que se define pela separação entre o mundo objetivo, criado pela razão, e o mundo da subjetividade, centrado na pessoa. Um início da libertação dos homens das desigualdades sociais, dos temores irracionais e da ignorância. Conforme Pourtois e Desmet (1999, p. 23), "é a da transparência tanto no nível científico como no social, a fim de lutar contra o arbitrário, a dependência e o conservadorismo".

Essa mudança subjetiva surgiria com a ideia do progresso, de ruptura com o passado tendo como marco histórico a revolução Francesa no seu caráter político e a revolução Industrial de caráter econômico:

O que é comumente chamado de "revolução industrial" foi o resultado da revolução ideológica efetuada pelas doutrinas dos economistas. Foram eles que explodiram velhos dogmas: que é desleal e injusto superar um competidor produzindo melhor e mais barato; que é iníquo desviar-se dos. 
métodos tradicionais de produção; que as máquinas são um mal porque trazem desemprego; que é tarefa do governo evitar que empresários fiquem ricos e proteger o menos eficiente na competição com o mais eficiente; que reduzir a liberdade dos empresários pela compulsão ou coerção governamental em favor de outros grupos sociais é um meio adequado para promover o bem estar nacional. A economia política inglesa e a fisiocracia francesa indicaram o caminho do capitalismo moderno. Foram elas que tornaram possível o progresso decorrente da aplicação das ciências naturais, proporcionando às massas benefícios nunca sequer imaginados (MISES, 2010, p. 25).

Nota-se que, até o século XVIII, as questões econômicas eram integrantes de estudos teológicos, seguindo a tradição presente na Idade Média, ou se inseriam tratados de ciência política. A economia precisou se tornar autônoma da teologia e da política para existir como ciência. Assim, no decorrer da história, a economia e a ética se distanciaram gradativamente, o que influenciou a conduta do ser humano nas concepções de bem-estar, nas prioridades políticas, na utilização dos recursos naturais e ambientais, o que provocou a alteração do comportamento da sociedade e da atuação das instituições.

Há, então, um despertar para a evolução do pensamento liberal, e suas tendências foram responsáveis pelo que conhecemos, atualmente, como modernidade. Nesse sentido, de acordo com Pourtois e Desmet (1999), a escola e a educação vieram como abertura e libertação para o conhecimento racional. Uma ruptura com o meio de origem para alcançar o progresso. "Trata-se também, de eliminar os privilégios, os herdeiros de um passado superado, para eleger elites em todo o corpo social, recrutada graças a concursos realizados sobre bases objetivas" (POURTOIS; DESMET, 1999, p. 23).

A modernidade trouxe grandes conquistas, favoreceu a construção de um mundo mais democrático, os direitos humanos se tornaram respeitados, houve grande avanço técnico-científico e permitiu o bem-estar à sociedade. No entanto, para Agostini (2001), estes avanços e nova estruturação da vida humana nem sempre trouxeram uma realização profunda do existir. Em Werber (2000, p. 73), "os laços da racionalidade tornam-se cada vez mais apertados, aprisionando-nos numa gaiola de rotina burocrática".

Nota-se que o desenvolvimento das sociedades modernas e sua propagação pelo mundo, deram aos seres humanos maiores possibilidades de desfrutarem uma existência mais segura e gratificante que as épocas anteriores, mas também apresentaram um lado sombrio. Conforme Giddens (1996, p. 16), “o mundo moderno se apresenta ao mesmo tempo poderoso e débil, capaz de realizar o ótimo e o péssimo, por quanto se lhe abre o caminho da liberdade ou da escravidão, do progresso ou do regresso, da fraternidade ou do ódio". 
Surge, então, a distância entre o homem antigo e o homem moderno, atingida por outro paradigma, a dimensão social e pessoal, alcançando as regiões mais profundas da existência humana. Um afastamento entre a ética e as questões econômicas, que foram sendo embasadas prioritariamente, na eficiência do crescimento do Produto Nacional Bruto e/ou Produto Interno Bruto, no acúmulo de bens e riquezas, no aprimoramento desmedido das táticas de competitividade, na acumulação de produtos e no aumento das exportações, a fim de expandir as divisas.

Nessa organização, os aspectos da moral e da justiça foram degredados à grau ínfimo de relevância, quando não desconsiderados na sua totalidade. O comportamento individualista de interesses, mesmo na tentativa de uma relação ética, normalmente apresenta uma ramificação entre o egoísmo e altruísmo, entre o indivíduo e o todo, distanciando o comportamento individual do comportamento social, ou seja, indivíduos de um mesmo grupo podem ter interesses que são em parte convergentes e em parte conflitantes.

Nesse contexto, nota-se a complexidade do conceito de desenvolvimento social citada no início da presente discussão, o que era esperado como evolução e transformação, para o bem da espécie, aparece, na contemporaneidade, em grande parte da população, principalmente em países considerados subdesenvolvidos, como uma circunstância pré-moderna de analfabetismo, pobreza, fome, falta de saúde, emprego. Desigualdades causadas pelo desenrolar do processo da modernização, cuja exacerbação do individualismo, da busca pelo bem-estar e conceitos que tinham como objetivo ações que garantissem a melhoria da qualidade de vida, acabaram transformando em ações que provocaram o aumento dos índices das desigualdades sociais.

\section{HISTÓRICO DA CONCEPÇÃO DE DESENVOLVIMENTO: do econômico ao humano e social}

O capitalismo é um sistema de produção de mercadorias, centrado sobre a relação entre a propriedade privada do capital e o trabalho assalariado. Uma relação de alicerce para o sistema de classes, cujo empreendimento capitalista depende da produção para mercados competitivos, os preços sendo sinais para investidores, produtores e consumidores. Para Smith (1988), é o nascimento da sociedade industrial, em que as consequências econômicas da divisão do trabalho, as consequências sociais da indústria para a estrutura das classes, o papel cada vez maior dos serviços e do trabalho improdutivo traz à luz os mecanismos da sociedade nascente.

No contexto da teoria da história, de Smith, o capitalismo representava o estágio mais alto da civilização e atingiria seu ponto culminante quando tivesse evoluído para um estado em que o governo tivesse adotado uma política de laissez-faire, permitindo que as forças da concorrência e o livre jogo da oferta e da demanda regulassem a economia, que ficaria quase que completamente livre das restrições do governo ou de suas intervenções [...] 
A acumulação do capital terá sido, então, a principal fonte de progresso econômico e os lucros terão sido a fonte do novo capital (HUNT, 2005, p. $54)$.

Neste sentido, o desenvolvimento econômico de um país gera acumulação de capital e incorporação de progresso técnico ao trabalho e ao capital, levando ao aumento da produtividade, dos salários, e do padrão médio de vida da população, mas não garante melhorias sociais, pois apesar dos progressos, as privações humanas persistem. No entanto, Smith (1988) percebia o desenvolvimento econômico como uma das principais condições para o alcance do desenvolvimento, ou melhor, para o autor o desenvolvimento econômico era o próprio desenvolvimento, assim:

As discussões de um conceito distinto de desenvolvimento começam por Schumpeter, no início do século XX, que atribui ao crescimento uma característica apenas expansiva, enquanto que o desenvolvimento, segundo o autor, somente ocorreria "na presença de inovações tecnológicas, por obra de empresários inovadores, financiados pelo crédito bancário. $\mathrm{O}$ processo produtivo deixa de ser rotineiro e passa a existir lucro extraordinário" (SOUZA, 1999, p.16).

Nota-se que o autor apresenta conceitos distintos de Smith (1988), porém ainda uma análise de desenvolvimento voltada estritamente para 0 econômico. De acordo com Boisier (2001) e Sachs (2004), o conceito de desenvolvimento debatido atualmente, distinto do conceito de crescimento econômico, deu-se no período pós-guerra com os preparativos para a reconstrução da Europa, pois se encontrava com uma:

[...] estrutura fundiária anacrônica, agricultura camponesa atrasada, condições adversas de comércio para as commodities primárias, industrialização incipiente, desemprego e subemprego crônicos, e necessidade de um Estado desenvolvimentista ativo para enfrentar o desafio de estabelecer regimes democráticos capazes simultaneamente de conduzir a reconstrução do pós-guerra e de superar o atraso social e econômico (SACHS, 2004, p. 30).

Diante da perspectiva, conclui que:

Em grande medida, o trabalho da primeira geração de economistas do desenvolvimento foi inspirado na cultura econômica dominante da época, que pregava a prioridade do pleno emprego, a importância do Estado de bem-estar, a necessidade de planejamento e a intervenção do Estado nos assuntos econômicos para corrigir a miopia e a insensibilidade social dos mercados (SACHS, 2004, p.31).

A partir de então, inicia-se a reflexão sobre um conceito de desenvolvimento com tendências voltadas ao ser humano, tendo como trajetória economistas como: o paquistanês Mahbub ul Haq e o indiano Amartya Sen. Na tentativa de tornar o desenvolvimento apreciável e condizente com as necessidades 
humanas, desenvolveram, no início da década de 1990, o Índice de Desenvolvimento Humano (IDH) que de acordo com o Programa das Nações Unidas para o Desenvolvimento (PNUD), é obtido através do PIB per capita, depois de corrigido pelo poder de compra da moeda de cada país e por outros dois componentes: a longevidade e a educação. Para aferir a longevidade, o indicador utiliza números de expectativa de vida ao nascer. O item educação é avaliado pelo índice de analfabetismo e pela taxa de matrícula em todos os níveis de ensino. A renda é mensurada pelo PIB per capita, em dólar PPC (paridade do poder de compra, que elimina as diferenças de custo de vida entre os países). Essas três dimensões têm a mesma importância no índice, que varia de zero (inexistência de desenvolvimento) a um (totalmente desenvolvido) (2009). E tem por objetivo ser um contraponto ao Produto Interno Bruto Per Capita (PIB per capita), que até então era o índice mais utilizado para se caracterizar uma região, mas que retrata apenas a dimensão econômica local.

Nota-se, com o IDH, uma evolução para o desenvolvimento, ou seja, um outro conceito para evidenciar a realidade das pessoas, não apenas na dimensão econômica, mas também levando em consideração as questões políticas, sociais e ambientais. No entanto, o próprio PNUD reconhece suas limitações, pois esse avanço tornou o pensar desenvolvimento mais completo, porém mais complexo e intangível:

Os autodenominados pós-modernos propõem renunciar ao conceito, alegando que o desenvolvimento tem funcionado como uma armadilha ideológica construída para perpetuar as relações assimétricas entre as minorias dominadoras e as maiorias dominadas, dentro de cada país e entre os países. Propõem avançar para um estágio de pósdesenvolvimento. Sem explicar claramente o seu conteúdo operacional concreto. Estão certos, por suposto, quando questionam a possibilidade de crescimento indefinido do produto material, dado o caráter finito do nosso planeta. Porém, esta verdade óbvia não diz muito sobre o que deveríamos fazer nas próximas décadas para superar os dois principais problemas herdados no século XX, apesar do seu progresso científico e técnico sem precedentes: o desemprego em massa e as desigualdades crescentes [...] (SACHS 2004, p. 26).

Nesse sentindo, o IDH torna-se, então, uma medida geral, porém sintética, visto que apesar de ter ampliado a perspectiva sobre o desenvolvimento humano não conseguiu abranger todos os aspectos de desenvolvimento. De acordo com o PNUD, suas conquistas em desenvolvimento humano ainda mascaram desigualdades, assim na tentativa de adequação, em 2010, foi introduzido o IDH Ajustado à Desigualdade (IDHAD), passando de um índice em "potencial" a um índice "real". 
com o resultado econômico graças ao "efeito cascata" - trickle down effect. Não há necessidade de uma teoria do desenvolvimento. Basta aplicar a economia moderna, uma disciplina a-histórica e universalmente válida [...] Essa teoria do efeito cascata seria totalmente inaceitável em termos éticos, mesmo se funcionasse, o que não é o caso. Num mundo de desigualdades abismais, é um absurdo pretender que os ricos devam ficar mais ricos ainda, para que os destituídos possam ser um pouco menos destituídos (SACHS 2004, p. 26).

O propósito do desenvolvimento, no contexto atual, não pode ser pensado exclusivamente no âmbito econômico, pois cerceia parte da população da dignidade humana, perpetuando o subdesenvolvimento. "Na verdade, o ponto central é como fazer um bom uso dos formidáveis benefícios do intercurso econômico e do progresso tecnológico de maneira a atender, de forma adequada, aos interesses dos destituídos e desfavorecidos" (SEN, 2010, p. 23).

A dimensão social da globalização é um assunto complexo e de grande abrangência. A interconexão entre pessoas do mundo inteiro e a capacidade produtiva do mercado global, com uma governança aberta e democrática permitiria benefícios a todos. Mas, sabe-se do muito que ainda se tem a fazer para que essa possibilidade se torne realidade. $O$ atual processo de globalização está produzindo resultados desiguais entre os países e dentro deles. Riquezas têm sido criadas, mas países e pessoas não participam dos benefícios gerados e têm poucas ou nenhuma participação no desenrolar do processo.

Vivemos igualmente em um mundo de privação, destituição e opressão extraordinárias. Existem problemas novos convivendo com os antigos - a persistência da pobreza e de necessidades essenciais não satisfeitas, fomes coletivas e fomes crônicas muito disseminadas, violação de liberdades políticas elementares e de liberdades formais básicas, ampla negligencia diante dos interesses e da condição de agente das mulheres e ameaças cada vez mais graves ao nosso meio ambiente e à sustentabilidade de nossa vida econômica e social (SEN, 2010, p. 9).

Superar essas dificuldades sociais faz parte do processo de desenvolvimento. Sen (2010) demonstra a relevância do papel das distintas formas de liberdades no combate a essas enfermidades. A promoção das liberdades necessita de fatores já evidenciados pelo conceito de desenvolvimento "unicamente" econômico, como o crescimento do Produto Nacional Bruto, o aumento das rendas pessoais, industrialização, avanço tecnológico e modernização social. No entanto, as liberdades dependem essencialmente de outros fatores ligados ao desenvolvimento humano como: a educação, a saúde, os direitos civis e a participação política.

Furtado (1983), afirma que o crescimento econômico não garante o desenvolvimento, ou melhor, para o autor, a geração de riqueza pode ser 
concentrada, sem distribuição, o que consequentemente não interferirá na melhoria da qualidade de vida das pessoas.

\begin{abstract}
O conceito de desenvolvimento compreende a ideia de crescimento, superando-a. Com efeito: ele se refere ao crescimento de um conjunto de estrutura complexa. Essa complexidade estrutural não é uma questão de nível tecnológico. Na verdade, ela traduz a diversidade das formas sociais e econômicas engendrada pela divisão do trabalho social. Porque deve satisfazer às múltiplas necessidades de uma coletividade é que o conjunto econômico nacional apresenta sua grande complexidade de estrutura. Esta sofre a ação permanente de uma multiplicidade de fatores sociais e institucionais que escapam à análise econômica corrente [...] O conceito de crescimento deve ser reservado para exprimir a expansão da produção real no quadro de um subconjunto econômico (FURTADO, 1983, p. 90).
\end{abstract}

A complexidade torna-se, então, uma abordagem para conceituar desenvolvimento, sem possibilidades de seguir modelos prontos voltados para o crescimento econômico, o qual restringe o seu caráter amplo, multidisciplinar e temporal, associado às mudanças sociais.

Para Sen (2002), as possibilidades que favorecem o processo de desenvolvimento apontam para além da industrialização, do progresso tecnológico e da modernização social. As disposições sociais e econômicas, como educação e saúde, e os direitos civis, como a liberdade política, são fatores de promoção de liberdades substantivas. Para o autor, o sucesso de uma sociedade deve ser avaliado, segundo a teoria do Desenvolvimento como Liberdade, através das liberdades substantivas, que os sujeitos de uma sociedade preestabelecida desfrutam. Assim, o modelo de avaliação de sucesso da sociedade difere do modelo de avaliação tradicional, com focos econômicos.

Na liberdade substantiva, há a permissão, possibilidade e autorização para a realização de algo, uma liberdade formal perante a lei. Mas, essa peculiaridade não capacita necessariamente a prática da ação. A capacidade das possibilidades substanciais e não jurídicas é a segunda peculiaridade da liberdade, ou seja, a liberdade real, de fato, substantiva e substancial:

\begin{abstract}
Essas liberdades substantivas (ou seja, a liberdade de participação política ou a oportunidade de receber educação básica ou assistência médica) estão entre os componentes constitutivos do desenvolvimento. Sua relevância para o desenvolvimento não tem de ser estabelecida a posteriori, com base em sua contribuição indireta para o crescimento do PNB ou promoção da industrialização. O fato é que essas liberdades e direitos também contribuem muito eficazmente pra o progresso econômico (SEN, 2000, p. 18).
\end{abstract}

Sen (2000), identifica o desenvolvimento como expansão das liberdades, por estar visivelmente relacionado com esse processo. Para o autor, o desenvolvimento não deve ser confundido com crescimento econômico, aumento da renda per capita ou incremento tecnológico. Mais do que isso, só é alcançado em sua plenitude quando as pessoas são livres para suprir suas necessidades. 
Para que o desenvolvimento seja realmente usufruído, é preciso banir as "principais fontes de privação de liberdade" (SEN, 2000, p. 18). São elas: "pobreza e tirania, carência de oportunidades econômicas e destruição social sistemática, negligência dos serviços públicos e intolerância ou interferência excessiva de Estados opressivos" (SEN, 2000, p. 18).

[...] A tônica nas liberdades humanas contrasta com perspectivas mais restritas de desenvolvimento, que o identificam com o crescimento do produto nacional bruto, com o aumento das receitas pessoais, com a industrialização, com o progresso tecnológico, ou com a modernização social. Considerar o desenvolvimento como expansão das liberdades substantivas orienta a ação para os fins que tornam o desenvolvimento algo importante, mais do que para os meios que desempenhem papéis de relevo. A liberdade é nuclear ao processo de desenvolvimento por duas ordens de razões: 1. Avaliação: a apreciação do progresso tem de ser feita em termos do alargamento das liberdades das pessoas; 2. Eficácia: a eficácia do desenvolvimento depende da ação livre das pessoas. O que as pessoas podem efetivamente realizar é influenciado pelas oportunidades econômicas, pelas liberdades políticas, pelos poderes sociais e por condições de possibilidade como a boa saúde, a educação básica, e o incentivo e estímulo às suas iniciativas (SEN, 2000, p. 25).

Nesse contexto, podem-se entender as liberdades humanas como a hegemonia do processo de desenvolvimento, uma eventualidade de processo conservador e empobrecido. O que se propõe então com as liberdades substanciais vai além das liberdades humanas, um processo contra-hegemônico de pertinência à democratização, com embates políticos e ideológicos, ações de atores sociais que suscitam inquietações, críticas participativas e construtivas, gerando oportunidades e componentes constitutivos para o desenvolvimento.

A própria criação do IDH vem dessas inquietações e passa a levar em conta não apenas a riqueza produzida pelo $\mathrm{PIB}$, mas também aspectos de saúde e educação, um conceito de desenvolvimento de caráter social, para o aprimoramento do ser humano em termos individuais, paradigma de melhoria para os membros da sociedade, uma vez que ela passa a ser uma sociedade transformada, participativa e globalizada.

Assim, em conformidade com Sen, porém no âmbito educacional, Freire (2007) apresenta a educação como saída para a libertação dos seres humanos da condição de desumanizados, pois o autor defende que a educação conduz o egresso da consciência ingênua para uma consciência crítica, que possibilite a saída da condição passiva para tornarem-se sujeitos da sua própria história, exercendo então, a sua condição de "agente".

Nesse cenário, a educação pode aparecer como instrumento de desenvolvimento social, possibilidade em que a sociedade pode adquirir melhores condições de vida, de maneira sustentável, pois a educação deveria transformar e libertar, desempenhando um papel fundamental em todas as camadas da população e proferindo respeito a todos e no decorrer de toda a vida. 
No entanto, notou-se a complexidade do processo, de modo que o desenvolvimento social também precisa de algumas considerações a respeito da paz, da igualdade, das oportunidades, do resgate dos valores que traz então, a necessidade de uma sociedade voltada para o conhecimento. Aspectos que talvez sejam difíceis de inserir isoladamente nos processos de desenvolvimento econômico.

Ponchirolli (2000) apresenta o capital humano como fundamental para a organização do futuro, se pensar em outras formas de observar 0 desenvolvimento. Para o autor, o aprender a conhecer, a fazer, a conviver e a ser, assim como Delors (2010), são habilidades e competências principais no mercado competitivo, necessárias para o século XXI. A pesquisa científica e educação são bases para a geração de riquezas. As organizações econômica e social estão centradas na posse da informação do conhecimento e na utilização do capital humano, ou seja, indivíduos capacitados e/ou especializados, detentores de um conjunto de conhecimentos, competências e atributos que favoreçam a realização de trabalho que produzam valor econômico.

\begin{abstract}
A competitividade internacional leva a modificações nos padrões de produção e consumo. Novas tecnologias de produção afetam a organização do trabalho, modificando cada vez mais o perfil do trabalhador necessário para esse novo tipo de produção. Surgem novas profissões, outras desaparecem. Há uma tendência de intelectualização do processo de produção implicando mais conhecimento, uso da informática e de outros meios de comunicação, habilidades cognitivas e comunicativas, flexibilidade de raciocínio, etc. (LIBÂNEO, 2001, p.15).
\end{abstract}

De acordo com Silva (2006), a Assembleia Geral da UNESCO da Comissão Internacional sobre Educação para o Século XXI, aprovou uma resolução a qual dizia que "a educação para o Desenvolvimento é a educação para a compreensão, a paz e a cooperação internacional e a educação relativa aos direitos do homem e às liberdades fundamentais". Um paradigma em que não basta saber fazer ou ter.

Delors e outros estabeleceram quatro pilares para a educação, sendo: Aprender a Conhecer, Aprender a viver juntos, aprender a viver com os outros e Aprender a ser.

Em tempos de rápida transformação, nota-se que houve uma transformação no conceito de educação, muda-se o mundo e afastam-se as possibilidades de continuar com uma educação tradicional e permanente, surgindo a necessidade de escolas que se comprometam com a educação de indivíduos preparados para enfrentar as diversas exigências dos campos existentes, da vida, do mercado, do mundo. Que capacitem a autonomia, o discernimento e a reponsabilidade de cada um diante do coletivo. Para Delors e outros (2006), a educação deve multiplicar as possibilidades de acesso a dados e fatos, permitindo que todos possam coletar, selecionar, ordenar, gerenciar e utilizar esse volume de informações e servir-se dele. A educação deve, portanto, adaptar-se constantemente às mudanças da sociedade, sem negligenciar as vivências, os saberes básicos e os resultados da experiência humana. 
Nesse contexto, uma educação que esteja voltada para a busca da liberdade, para a paz, para o desenvolvimento sustentável, seja ele humano, social, cultural, ambiental ou econômico. De acordo com Delors e outros (2006), o mundo vive conflitos provocados por intolerância religiosa e por situações de violência causadas pelas condições de extrema pobreza, verificadas em diversos países. Não se pode chegar a um desenvolvimento pleno, se não se difundir uma cultura de não violência, de tolerância e cooperação:

\footnotetext{
A Educação para o Desenvolvimento visa a conscientizar a opinião pública para as questões da solidariedade e da interdependência das regiões do mundo e, em particular, para a realidade econômica, política, social e cultural dos países do Sul geopolítico. Nesse sentido, a ED visa a capacitar vários segmentos da opinião pública para uma melhor análise da informação e das políticas locais, nacionais e internacionais, ligadas aos desequilíbrios mundiais, permitindo mudanças dos comportamentos sociais individuais e/ou grupais e propostas de ação, norteadas por preocupações de sustentabilidade dos processos de desenvolvimento. A Educação para o Desenvolvimento promove o direito de todas as pessoas, e de todos os povos, a participar e contribuir para o desenvolvimento econômico, social, político e cultural.

A Educação para o Desenvolvimento (ED) é um processo dinâmico, interativo e participativo que visa:

. À formação integral das pessoas;

. À vivência da interculturalidade;

- Ao compromisso para a ação transformadora alicerçada na justiça, equidade e solidariedade;

- A promoção do direito e do dever de todas as pessoas, e de todos os povos, participar e contribuir para um desenvolvimento integral e sustentável (SILVA, 2006, p.122).
}

Assim, a educação vem com o desafio de estimular mudanças de atitude e comportamento para a construção de um outro perfil populacional, uma vez que as capacidades intelectuais, morais e culturais do homem impõem responsabilidades para com outros seres vivos e para com a natureza como um todo.

De acordo com Becker (2008), no Brasil, a Lei das Diretrizes e Bases da Educação no 9.394/96 (LDB, 2006), em seu artigo 1ํ "A educação abrange os processos formativos que se desenvolvem na vida familiar, na convivência humana, no trabalho, nas instituições de ensino e pesquisa, nos movimentos sociais e organizações da sociedade civil e nas manifestações culturais", por meio dela o ser humano se apropria do conhecimento para utilizá-lo em seu próprio desenvolvimento.

A educação problematizadora através da pesquisa pode apresentar-se neste contexto, de acordo com freire (1988), como uma prática para a liberdade do sujeito, uma liberdade de consciência e clareza para entender e mirar a realidade vivenciada, dando a condição de agir e transformar o que vive, desenvolvendo-se e suscitando desenvolvimento humano e social. 
Nesse sentido, é relevante uma transformação na postura do professor, para uma prática de ensino aprendizagem reflexiva. De acordo Schön (1992), tanto professor quanto estudante, precisam de postura crítico-reflexiva contextualizada sobre o conteúdo, em suas práticas pedagógicas. Pois, praticas reflexivas implicam em pensar temas na perspectiva de situações-problema, refletindo e problematizando sobre objetos, acontecimentos ou conceitos que são os objetos da prática.

Assim, através do estudo, nota-se que diante de toda complexidade inerente ao processo, a educação contemporânea que transforma e liberta, passa a ser um caminho privilegiado na consolidação de valores e comportamentos sustentáveis para o desenvolvimento.

\section{CONSIDERAÇÕES FINAIS}

O presente texto apresentou, em reflexões breves e focadas, a complexidade e a demanda de esforços para o alcance dos desenvolvimentos humano e social. Expôs ainda aspectos relevantes e contribuições de autores sobre o desenvolvimento econômico e suas carências, para abranger arranjos proeminentes do desenvolvimento; que se pensado e considerado apenas no âmbito econômico, parte da população pode ser cerceada de sua dignidade. Apresenta, por fim, a possibilidade da educação problematizadora, através da pesquisa, como um caminho de aprimoramento das potencialidades de sujeitos, para fazer diferente, propiciando transformações que podem ser gestadas em ações que materializem melhores condições de vida, capazes de assumirem fatores determinantes da existência individual e social.

A modernidade e seu desenvolvimento trouxe à humanidade desfrutes inimagináveis em tempos anteriores, porém apresentou complexidades intangíveis e de difícil reversão: a competitividade desenfreada afastou a ética das questões econômicas, o individualismo e a concentração de rendas agrava as desigualdades sociais e humanas, sem falar da degradação de aspectos como a moral e a justiça.

Assim, o que era esperado de evolução e transformação, como bem para humanidade e garantia de qualidade de vida, surge na contemporaneidade em grande parte da população como privação, em que muitos não têm acesso aos bens mais essenciais para a sobrevivência. A razão exclusiva não atendia plenamente às necessidades humanas.

A globalização vem acontecendo numa configuração acelerada e desenfreada, sem a participação justa, equitativa e efetiva dos menos favorecidos. Ou seja, o atual processo de globalização é um artifício complexo e ainda há muito o que fazer e melhorar para a produção de resultados menos desiguais.

Nesse contexto, esta discussão apresenta uma possibilidade olhares para a superação, a partir das teorias de Amartya Sen e Freire, na tentativa de 
progresso dessas dificuldades sociais, com outras formas de desenvolvimento, que não apenas o econômico, em combate às enfermidades enraizadas na sociedade. Tendo na educação a confiança para a conquista das liberdades individuais, poucas vezes valorizada no mundo em que vivemos, pois é a partir dela que a população se torna ativa e pode incomodar as camadas mais abastadas dessa sociedade.

A educação consiste em dotar a humanidade da capacidade de dominar o seu próprio desenvolvimento e fazer com que cada pessoa seja responsável pela construção do seu próprio conhecimento e contribua para o progresso da sociedade em que vive, ou seja, a educação deve ser um instrumento de desenvolvimento social, que possibilite a aquisição de melhores condições de vida, de maneira sustentável, ela pode transformar, libertar e desempenhar um papel fundamental em todas as camadas da população e proferir respeito a todos e no decorrer de toda a vida.

Para isso, não se deve esquecer as lições do "aprender a ser", e dos outros pilares da educação, que não negligenciam as potencialidades dos indivíduos: memória, raciocínio, capacidade física, sentido estético, aptidão para a oralidade; potenciais que possibilitam acesso a dados, fatos e informações para servirem-se deles; pois é sabido que o mundo está em transformação rápida e constante, assim não é possível, na educação, mais do mesmo, as escolas necessitam educar indivíduos que estejam preparados para as exigências do tempo presente e dos que virão, capacitando e se responsabilizando com a formação humana, com olhar para o coletivo e para o outro.

A educação deve, portanto, adaptar-se constantemente às mudanças da sociedade, sem negligenciar as vivências, os saberes básicos e os resultados da experiência humana.

\section{REFERÊNCIAS}

AGOSTINI, N. Condicionamentos e manipulações: desafios morais. In: O itinerário da fé na "iniciação cristã dos adultos". Estudos da CNBB, n. 82, São Paulo: Paulus, 2001. p. 103.

BECKER, Alexandre. A concepção de educação de Paulo Freire e o desenvolvimento sustentável. 2008. 87 f. (Mestrado em Organizações e desenvolvimento). UNIFAE - Centro Universitário Franciscano, Curitiba, 2008. Disponível em: <file://C:/Users/usuario/Downloads/1547874526580186\%20(1).pdf>. Acesso em abr. 2017.

BOISIER, Sérgio. Desarrollo (local): ¿de qué estamos hablando? In: MADOERY, Oscar y VÁZQUEZ BARQUERO, Antonio (eds). Transformaciones globales: instituciones y políticas de desarrollo local. Rosário: Editorial Homo Sapiens, 2001. 
FORMAÇÃO DOCENTE: UM PROCESSO EM CONTÍNUA CONSTRUÇÃO DE CONHECIMENTOS ISBN: 978-85-5453-030-3

\begin{tabular}{lr}
\hline Disponível em: & hhttp://www.opet.com.br/faculdade/revista-cc-adm/pdf/n3/DO- \\
CRESCIMENTO & ECONOMICO-AO-DESENVOLVIMENTO-SUSTENTAVEL- \\
CONCEITOS-EM-EVOLUCAO.pdf > . Acesso em 05 de abr. de 2017.
\end{tabular}

DELORS, Jacques. Educação: um tesouro a descobrir. Relatório para a Unesco da Comissão Internacional sobre Educação para o século XXI. Tradução de Guilherme João de Freitas Teixeira. UNESCO - Brasília, 2010. Disponível em: < http://unesdoc.unesco.org/images/0010/001095/109590por.pdf>. Acesso em $11 \mathrm{de}$ abr. 2017.

. Educação: um tesouro a descobrir. Relatório para a Unesco da Comissão Internacional sobre Educação para o Século XXI. Tradução de Guilherme João de Freitas Teixeira. 10. ed. Editora Cortez, 2006.

FREIRE, Paulo. Pedagogia da autonomia: saberes necessários à prática educativa. 36. ed. São Paulo: Paz e Terra, 2007.

FURTADO, Celso. Dialética do desenvolvimento. Rio de Janeiro: Fundo de Cultura, 1964.

- Teoria e política do desenvolvimento econômico. 8. ed. São

Paulo: Ed. Nacional, 1983.

GIDDENS, Anthony. As consequências da modernidade. São Paulo: UNESP, 1991.

- Para além da esquerda e da direita: o futuro da política radical. Tradução: Alvaro Hattnher. São Paulo: UNESP, 1996.

HUNT. E K. História do pensamento econômico: uma perspectiva crítica. 2. ed. Rio de Janeiro: Elsevier, 2005.

KANT, Immanuel. A paz perpétua e outros opúsculos. Lisboa: Edições 70, 1993.

KANT, Immanuel. Sobre a pedagogia. Tradução de Francisco Cock Fontanella. Piracicaba: Editora Unimep, 1996.

LIBÂNEO, José Carlos. Democratização da escola pública. 3. ed. São Paulo: Loyola, 1990.

Cortez, 1994.

Tendências pedagógicas do Brasil e a didática. São Paulo:

Organização e gestão da escola: teoria e prática. Goiânia:

Editora Alternativa, 2001.

GUERRA, Sandra Aparecida Ferreira; OLIVEIRA, Sheila Fernandes Pimenta e; GUERRA, José Alfredo de Pádua 
MELLO, Vico Denis S. de; DONATO Manuella Riane $A$. O pensamento iluminista e o desencantamento do mundo: Modernidade e a Revolução Francesa como marco paradigmático. Alagoas, n.4, p.261-262, dez. 2011. Disponível em: <http://www.revista.ufal.br/criticahistorica/attachments/article/118/0\%20Pensamento \%20lluminista\%20e\%200\%20Desencantamento\%20do\%20Mundo.pdf>. Acesso em 30 de mar. 2017.

MISES, Ludwig Von. Ação Humana. 31. ed. São Paulo: Instituto Ludwig Von Mises Brasil, 2010, 25 p. Disponível em: <http://www.oretrogrado.com.br/wpcontent/uploads/2016/07/Acao-Humana-Um-Tratado-de-Ec-Ludwig-von-Mises.pdf>. Acesso em 26 de abr. de 2017.

OLIVEIRA, Juliano Diniz de. Ordem, Instituições e Governança: uma análise sobre o discurso do desenvolvimento no Sistema ONU e a construção da ordem internacional. 2010, 124 f. (Dissertação em Relações Internacionais) PUC-Rio, Rio de Janeiro, 2010. Disponível em: <https://www.maxwell.vrac.pucrio.br/16658/16658_4.PDF>. Acesso em 30 de mar. de 2017.

OLIVEIRA, N., \& MARIOTTO, V. Televisão, educação e crianças: os desafios da escola e da família. Revista de Educação, Cultura e Comunicação, 2010, p. 39-45. Disponível em: <http://pepsic.bvsalud.org/pdf/rspagesp/v16n1/v16n1a05.pdf > Acesso em 16 de ago. de 2017.

OLIVEIRA, Raquel Vieira de. História da educação no Brasil. Trabalhos acadêmicos, p. $\quad 01,2006$. Disponível em <http://www.zemoleza.com.br/trabalhoacademico/sociais-aplicadas/filosofia/historia-da-educacao-no-brasil-2/>. Acesso em 05 de mar. 2017).

PONCHIROLLI, Osmar. O capital humano como elemento estratégico na economia da sociedade do conhecimento sob a perspectiva da teoria do agir comunicativo. 2000, Dissertação (Mestrado) UFSC. Florianópolis, 2000. Disponível em: $<$ https://repositorio.ufsc.br/bitstream/handle/123456789/79048/176828.pdf?sequene $=1>$. Acesso em 10 de abr. 2017.

POURTOIS, J.P. e DESMET, H. A Educação pós-moderna. Tradução de Yvone Maria de Campos Teixeira da Silva. São Paulo: Loyola, 1999.

SACHS, Ignacy. Desenvolvimento: includente, sustentável, sustentado. Rio de Janeiro: Garamond, 2004. Disponível em: <http://www.opet.com.br/faculdade/revistacc-adm/pdf/n3/DO-CRESCIMENTO-ECONOMICO-AO-DESENVOLVIMENTOSUSTENTAVEL-CONCEITOS-EM-EVOLUCAO.pdf>. Acesso em 05 de abr. de 2017. 
SEN, Amartya. O Desenvolvimento como Liberdade. Tradução: Laura Teixeira Motta. 2. ed. São Paulo: Companhia das Letras, 2000.

. O Desenvolvimento como Liberdade. Tradução: Laura Teixeira Motta.

3. ed. São Paulo: Companhia das Letras, 2002.

. Sobre ética e economia. Tradução: Laura Teixeira Mota. São Paulo. Companhia das Letras: 1999.

. Desenvolvimento como liberdade. Tradução: Laura Teixeira Motta. São Paulo: Companhia das letras, 2010.

. A ideia de justiça. Tradução: Denise Bottmann e Ricardo Doninelli Mendes. São Paulo: Companhia das letras, 2011.

SEN, A. KLIKSBERG, B. As pessoas em primeiro lugar: a ética do desenvolvimento e os problemas do mundo globalizado. São Paulo: Companhia das Letras, 2010.

SILVA, Christian L. (Org.). Desenvolvimento sustentável: um modelo analítico integrado e adaptativo. Petrópolis: Vozes, 2006.

SMITH, A. A riqueza das nações: investigação sobre sua natureza e suas causas. Tradução de Luiz João Baraúna. São Paulo: Nova cultural, 3 vol., 1988.

SOUZA, Nali de Jesus. Desenvolvimento econômico. 4. ed. São Paulo: Atlas, 1999. Disponível em: <http://www.opet.com.br/faculdade/revista-cc-adm/pdf/n3/DOCRESCIMENTO-ECONOMICO-AO-DESENVOLVIMENTO-SUSTENTAVELCONCEITOS-EM-EVOLUCAO.pdf>. Acesso em 05 de abr. de 2017.

TERMAS, Richard. A Epopeia do Pensamento Ocidental: para compreender as ideias que moldaram nossa visão de mundo. Rio de Janeiro: Bertrand Brasil, 2000. Disponível

em: <http://www.ucs.br/ucs/tplcinfe/eventos/cinfe/artigos/artigos/arquivos/eixo_tematico9/ Educacao\%20e\%20Autonomia\%20no\%20lluminismo.pdf>. Acesso em 30 de mar de 2016.

TODOROV, Tzvetan. O Espírito das Luzes. São Paulo: Barcarolla, 2008. Disponível em:

<http://www.ucs.br/ucs/tplcinfe/eventos/cinfe/artigos/artigos/arquivos/eixo_tematico9/ Educacao\%20e\%20Autonomia\%20no\%20lluminismo.pdf>. Acesso em 30 de mar de 2016. 
FORMAÇÃO DOCENTE: UM PROCESSO EM CONTÍNUA CONSTRUÇÃO DE CONHECIMENTOS ISBN: 978-85-5453-030-3

WEBER, M. Ensaios de sociologia. Rio de Janeiro: LTC, 1982. Disponível em: $<$ https://www.maxwell.vrac.puc-rio.br/10103/10103_3.PDF>. Acesso em 03 de março de 2017.

Claret, 2003.

A Ética protestante e o espírito do capitalismo. São Paulo: Martin 


\title{
ESTÁGIO DOCÊNCIA NA FORMAÇÃO DO DOCENTE DO ENSINO SUPERIOR: relato de experiência
}

\author{
MACHADO NETO, Alfredo José \\ Doutor em Administração - Uni-FACEF \\ alfredo@facef.br \\ LUCAS, Cecy de Sousa \\ Mestranda em Desenvolvimento Regional - Uni-FACEF \\ cecy_lucas06@yahoo.com.br \\ OLIVEIRA, Sheila Fernandes Pimenta e \\ Doutora em Língua Portuguesa e Linguística - Uni-FACEF \\ sheilafacef@gmail.com
}

\section{INTRODUÇÃO}

O estágio de docência é uma atividade recente para a pós-graduação stricto sensu. É um processo composto por muitos desafios, questionamentos, reflexões e desconstruções. É de fundamental importância para o aluno que está no mestrado e doutorado, que pretende ser docente, uma vez que o mesmo vai proporcionar uma reflexão-ação e faz parte da construção da identidade como um docente de ensino superior.

Além disso, o processo do estágio supervisionado corresponde à oportunidade do futuro profissional demonstrar ser capaz de enxergar os desafios cotidianos e encará-los com tranquilidade. Permite a compreensão de que o papel do docente não é apenas reproduzir e transmitir o conhecimento, mas também estimular e instigar os discentes para que possam construir e reconstruir conceitos, valores, habilidades e atitudes. Possibilita ainda, perceber que o docente necessita ser um profissional autônomo, criativo e reflexivo sobre sua atividade docente, e principalmente um cidadão consciente e crítico.

Portanto, ter a chance ou oportunidade de realizar um estágio para o exercício da docência, permite compreender as dinâmicas da atividade, aproximar a convivência com o espaço da sala de aula, bem como desenvolver uma postura consciente e crítica da profissão. São tais vivências incorporadas ao conhecimento teórico adquirido pelo professor durante seu processo de formação, que servirão de base para as futuras atividades de docência.

Baseado neste contexto, o trabalho tem como objetivo geral descrever as atividades planejadas e desenvolvidas, em estágio de docência, por uma mestranda da área de desenvolvimento regional, no curso de Administração de uma 
Instituição de Ensino Superior pública municipal, a fim de estabelecer parâmetros de formação de professores para o ensino superior e avaliar as práticas da atividade, como forma de contribuir para a formação de capital humano no referido segmento.

Para alcançar esses objetivos, foi realizada uma pesquisa bibliográfica com subsídios em Perrenoud (2002), Vasconcelos (2000), Veiga (2009), dentre outros, a fim de discutir a formação docente para o ensino superior. Ainda foi realizada uma pesquisa documental, para tratar dos marcos legais considerados pela CAPES, necessários para a realização do estágio de docência.

Além disso, o trabalho apresenta uma abordagem qualitativa, que procura compreender a experiência de uma mestranda através de um relato de experiência.

Portanto, este trabalho está dividido em cinco partes sendo, a primeira composta por esta introdução.

A segunda parte apresenta aspectos da formação de professores para o ensino superior, abordando os marcos teóricos e os marcos legais.

$\mathrm{Na}$ terceira parte, trabalha questões relativas ao lugar do estágio docência: a teoria e a prática, trazendo uma contextualização histórica, além de uma abordagem do estágio de docência e do mestrado em Desenvolvimento Regional relatando um pouco sobre a instituição de ensino superior e a relação com o estágio.

A quarta parte apresenta um relato da experiência, analisando a parte metodológica juntamente com os resultados obtidos, conforme estabelecido por Pádua (2004) e Chizzotti (2001).

Por último, são apresentadas as conclusões e as considerações finais a respeito do trabalho, buscando fazer um link entre a abordagem teórica e a experiência prática da mestranda.

\section{FORMAÇÃO DE PROFESSORES PARA O ENSINO SUPERIOR}

A formação de professores para o ensino superior envolve a compreensão da importância do papel da docência, propicia um profundo estudo cientifico-pedagógico que capacita o docente a enfrentar os desafios da instituição e da sala de aula, e promove uma prática que permite formar ideias críticas e reflexivas.

\subsection{Marcos teóricos}

A palavra docência tem suas raízes no latim docere, que tem como definição ensinar, instruir, indicar. Já no sentido formal, docência significa o trabalho dos docentes, que atualmente vem mudando o cenário, pois não se limita apenas à tarefa de ministrar aulas, envolvendo muitas outras atividades (VEIGA, 2009) 
O artigo 13 da Lei oํ 9.394/96 dispõe que são atribuições do professor: participar da elaboração do projeto pedagógico; elaborar e cumprir o plano de trabalho; zelar pela aprendizagem dos alunos; estabelecer estratégias de recuperação para alunos de menor rendimento; ministrar os dias letivos e horas-aula estabelecidos; participar integralmente dos períodos dedicados ao planejamento, à avaliação e ao desenvolvimento profissional.

O termo formação vem do latim formare, que é um verbo, que pode ser transitivo ou intransitivo. Como verbo transitivo, significa dar forma e, como verbo intransitivo, colocar-se em formação, como verbo pronominal, o processo de formação do indivíduo (VEIGA, 2009).

A formação de professores constitui o ato de formar o docente, educar o futuro profissional para o exercício do magistério. Envolve uma ação a ser desenvolvida (VEIGA, 2009).

No Brasil, até a década de 70, as faculdades contratavam professores que eram profissionais renomados, que tinham sucesso na vida profissional e os convidavam para ensinar a seus alunos a serem bons profissionais como eles, onde o professor transmitia o que sabia a respeito de uma determinada área para os alunos. Portanto, os alunos adquiriram conhecimento a partir dos conhecimentos e experiências profissionais dos professores (MASETTO, 2013).

Naquela época, eram exigidos do docente universitário apenas o curso de bacharel e o exercício competente de sua profissão. Ensinar significava ministrar aulas expositivas ou palestras sobre determinado assunto de domínio, mostrar na prática como se fazia; e isso qualquer profissional saberia fazer (MASETTO, 2013).

Vasconcelos (2000) vem questionar isso dizendo: Até que ponto, se pode permitir que o "professor" universitário, sem qualquer formação pedagógica, aprenda a ministrar aulas por ensaio e erro, desconsiderando o aluno.

Ela complementa dizendo que a competência pedagógica não é apenas dominar técnicas e métodos, e sim muito mais do que isso, ou seja, envolve uma mudança de postura do profissional frente ao ato pedagógico, ao desempenho do papel de docente, passando a ser um profissional mais responsável e comprometido.

Outro aspecto importante é que o aluno não era o centro do processo, e sim o professor. Eles tinham como principais preocupações se os professores eram competentes, atualizados em seus conhecimentos e suas experiências, se eram produtores de conhecimentos e pesquisadores, se eram capazes de transmitir conhecimento em sala de aula e serem avaliadores. Para eles, naquele período, aprender tinha significado de ter capacidade de repetir em provas o que o professor havia ensinado em aula (MASETTO, 2013).

Para Vasconcelos (2000), o docente de ensino superior deveria aliar o conhecimento especifico de seu domínio com a habilidade de educar. 
Pode-se dizer que, desde a década de 70, esse questionamento a respeito da capacitação e atualização do docente do ensino superior vem sendo uma preocupação nas universidades brasileiras. Mas foi nos anos 80, que começaram a surgir diversas disciplinas, em cursos de pós-graduação, voltadas para o magistério superior e os vários cursos de especialização e de reciclagem pedagógica, com objetivo de discutir, com seus docentes, a questão do conhecimento pedagógico e da sua utilização no desempenho profissional, enquanto professores do ensino superior (VASCONCELOS, 2000).

Um dado relevante, é que, na década de 70, surgiu uma política de formação de professores para o ensino superior, que visava qualificar o docente através de cursos que enfatizavam, basicamente, a questão da pesquisa, deixando a ação pedagógica do professor em segundo plano. $O$ que se observa é que existe pouca preocupação com a formação pedagógica dos mestres e doutores oriundos dos diversos cursos de pós-graduação do país (VASCONCELOS, 2000).

Mas, nos últimos anos, esse cenário vem mudando, e os professores universitários começaram a ter a formalização do que é a docência, e de que é necessário ter capacitação própria e específica, assim como qualquer outra profissão. Isso não restringe a ter um diploma de bacharel, ou mesmo de mestre ou doutor, ou, ainda, apenas o exercício de uma profissão. É isso tudo mais as competências necessárias (MASETTO, 2013).

Portanto, se perguntássemos quem deveria ser profissional ideal para o ambiente universitário? E a resposta seria a seguinte: deve ser um indivíduo com três capacidades desenvolvidas: a do bom transmissor de conhecimentos, ou seja, aquele que sabe ensinar; a do bom crítico das relações socioculturais da sociedade que o cerca; e a do bom pesquisador, capaz de, através de estudos sistemáticos e de investigações, produzir o novo e induzir o aluno a também criar (VASCONCELLOS, 2000).

Ao trazer esse questionamento para nossa realidade, veremos apenas alguns profissionais com uma ou duas dessas competências e uma minoria com as três. Vamos encontrar profissionais com a figura de um excelente professor transmissor de conhecimento, a figura de um professor conscientizador que preocupa com questões socioculturais e deixa de lado a função de formação, não transmite conhecimento. Tem a figura do pesquisador emérito que pega poucas aulas e por fim, o profissional que concilia à docência com a pesquisa, com carga de aula maior (VASCONCELOS, 2000).

Podemos dizer que o processo de docência no ensino superior é saber ter profissionalismo e não apenas dominar o conhecimento e transmitir. Ela deve ser vista como qualquer outra profissão. O docente ao preparar a aula fazer deve fazer a seguinte pergunta: "O que meus alunos precisam aprender para se tornar cidadãos profissionais competentes numa sociedade contemporânea?". É colocar a 
aprendizagem na prática como objetivo central da formação dos alunos (VEIGA, 2009).

Os profissionais docentes devem ter como características: ter capacidade de buscar novas informações e saber trabalhar com elas; saber trabalhar com novas ferramentas da informática; saber comunicar com essa nova era da informática; saber usar os recursos tecnológicos para melhorar a vida da população; e promover o desenvolvimento humano e social do país (VEIGA, 2009).

No Brasil, nas duas últimas décadas, começou-se a perceber que a pós-graduação - a docência de ensino superior necessita do desenvolvimento de competências próprias, como a pesquisa necessita. E que, ao desenvolver essas competências, também mudará o cenário de uma profissão em que, antes, o profissional dizia que ensinava por boa vontade, dava aula apenas por ter o título de professor de universidade, para complementar o salário, ou para preencher o tempo vago no dia (MASETTO, 2013).

Dentre essas competências a serem desenvolvidas podemos mencionar a técnica, a prática, a cientifica e a pedagógica. A formação prática, ou seja, a prática profissional vai ajudar a dar exemplos, irá criar condições de concretizar, favorecendo a maior instrumentalização do aluno para trabalhar com a realidade (VASCONCELOS, 2000).

Já em se tratando da competência técnico-cientifica do professor, é preciso manter-se sempre em atualização, seja por parte dele próprio, e, principalmente, por parte da universidade. Deve ser constante o aprendizado por parte do professor, com participações em simpósios, congressos, cursos e outras atividades, que irão promover não só a atualização, como também criar as condições e estimular a produção científica do próprio professor, que deveria estar naturalmente interessado em sua educação permanente.

Por último, mas não menos importante, a competência pedagógica vai além do simples saber ministrar a aula. Abrange aspectos do planejamento do ensino, desde a definição dos objetivos, a seleção de conteúdo, a distribuição de atividades e o processo de avaliação. , enfim ao planejamento dos cursos, a elaboração de programa das diferentes disciplinas, das possibilidades de construção e reconstrução do conhecimento, da relação professor-aluno, interação, parceria.

O autor Perrenoud (2002) levanta uma questão a respeito da formação dos professores dizendo por que formar professores para que possam refletir sobre sua pratica? E diante dessa pergunta ele vem nos mostrar dez motivos que a prática reflexiva pode atuar favorecendo como (Perrenoud, 2002, p. 48):

- Compensar a superficialidade da formação profissional;

- Favorecer a acumulação de saberes de experiência;

-Propiciar uma evolução rumo a profissionalização;

- Preparar para assumir uma responsabilidade política e ética;

- Permitir enfrentar a crescente complexidade das tarefas;

- Ajudar a vivenciar um ofício impossível; 
- Oferecer meios necessários para trabalhar sobre si mesmo;
-Estimular a enfrentar a irredutível alteridade do aprendiz;
-Aumentar a cooperação entre colegas;
-Aumentar as capacidades de inovação.

Esses dez motivos são para formar os professores e para motivá-los a refletir sobre sua pratica e eles poderiam ser resumidos em uma ideia principal: a construção do sentido, seja do trabalho e da escola, seja da própria vida.

A prática reflexiva é uma relação com o mundo de forma ativa, critica e a autônoma, portanto, depende mais de uma postura do que de uma competência pedagógica. Então uma formação em resolução de problemas, mesmo no sentido amplo, incluindo a identificação, e renunciando a todo procedimento padronizado, não é suficiente para formar um profissional reflexivo.

\subsection{Marcos legais}

Os primeiros passos da pós-graduação no Brasil foram dados, a partir de 1930, com a proposta do Estatuto das Universidades Brasileiras. Entretanto, mas foi em 1965 com o Parecer no 977/65 de 3 de dezembro de 1965 do Conselho Federal de Educação, emitido por Newton Lins Buarque Sucupira, que se deu de forma definitiva a implantação formal dos cursos de pós-graduação no Brasil, e instituíram os cursos de mestrado e doutorado no Brasil, baseado em modelos de outros países mais desenvolvidos.

Esse parecer de 1965 vem regulamentar e definir os cursos de pósgraduação e as suas características, bem como diferenciar pós-graduação stricto sensu e lato sensu. Ele é composto por alguns tópicos como: a origem da pósgraduação, sua necessidade, seu conceito, o exemplo da pós-graduação nos Estados Unidos, a pós-graduação na LDB de 1961, a pós-graduação e o Estatuto do Magistério, e a definição e caracterização da pós-graduação.

Pode-se dizer que esse parecer continua sendo a grande, referência sistemática da pós-graduação em nosso país (CURY, 2005).

O parecer apóia-se no art. 69 da lei nำ 4.024, de 20/12/1961 (LDB):

Art. 69. Nos estabelecimentos de ensino superior podem ser ministrados os seguintes cursos:

a) de graduação, abertos à matrícula de candidatos que hajam concluído o ciclo colegial ou equivalente, e obtido classificação em concurso de habilitação;

b) de pós-graduação, abertos a matrícula de candidatos que hajam concluído o curso de graduação e obtido o respectivo diploma;

c) de especialização, aperfeiçoamento e extensão, ou quaisquer outros, a juízo do respectivo instituto de ensino, abertos a candidatos com o preparo e os requisitos que vierem a ser exigidos.

E diante desse artigo descrito na Lei de Diretrizes e Bases, fica bem claro que ao definir oficialmente a pós-graduação, faltar-lhe-ia, por enquanto, 
competência para fazer a regulamentação geral dos cursos pós-graduados. Isto significa que, no atual regime da Lei de Diretrizes e Bases, qualquer estabelecimento, universidade ou faculdade isolada, poderia instalar cursos de pósgraduação conferindo grau, na forma da definição proposta pelo Conselho, mas sem depender, para isso, da autorização ou reconhecimento.

No parecer nos mostra o Estatuto do Magistério, em que o Conselho dispõe, dá poderes para submeter os cursos pós-graduados a uma certa regulamentação, ou seja, o controle dos cursos poderá ser feito por meio de reconhecimento. Esse reconhecimento, ou qualquer outro meio de controle, é indispensável, favorecendo o controle da implantação de novos cursos de pósgraduação.

Além disso, no parecer menciona que os cursos de pós-graduação devem ser aprovados pelo Conselho Federal de Educação, para que seus diplomas sejam registrados no Ministério da Educação e possam produzir efeitos legais. Para isso o Conselho baixará normas fixando os critérios de aprovação dos cursos.

Diante disso, ou seja, da necessidade de um órgão para avaliar e autorizar o funcionamento dos cursos de pós-graduação, em dezembro de 2017, Presidente da Câmara de Educação Superior do Conselho Nacional de Educação aprova a Resolução no 7, de 11 de dezembro de 2017 que vai estabelecer normas para o funcionamento de cursos de pós-graduação stricto sensu.

Essa resolução diz que são programas institucionais de pós-graduação stricto sensu os cursos de mestrado e doutorado regulares, pertencentes ao Sistema Nacional de Pós-Graduação, avaliados pela Coordenação de Aperfeiçoamento de Pessoal de Nível Superior (Capes), submetidos à deliberação pela Câmara de Educação Superior do Conselho Nacional de Educação (CES/CNE) e homologados pelo Ministro da Educação.

Além disso, no artigo $4^{\circ}$ diz que o processo de autorização, reconhecimento e a renovação do reconhecimento de cursos de mestrado e doutorado dependem de avaliação prévia da Capes. E o órgão da CAPES que irá tornar público o processo a cada ciclo avaliativo.

No artigo 6ํㅜ, complementa, dizendo que poderá desativar os cursos de stricto sensu em funcionamento caso não alcance a nota mínima no processo de avaliação do curso. E as atividades dos cursos de mestrado e doutorado só poderão iniciar a partir da publicação e da publicação da homologação do parecer favorável da CES/CNE pelo Ministro da Educação.

A CAPES também será responsável por alterar a nomenclatura de cursos de mestrado e doutorado a qualquer tempo.

E, por fim, a respeito dos diplomas dos cursos de mestrado e doutorado regulares, eles terão validade a nível nacional, e as instituições poderão 
emitir e registrar diplomas de cursos de mestrado ou doutorado por elas regularmente ofertados.

\section{O lugar do estágio docência: a teoria e a prática}

No presente item, apresentam-se breves discussões teóricas e vivenciais sobre o estágio de docência, destacando os aspectos positivos e os problemas com os quais um mestrando pode se deparar com as experiências em sala de aula.

\subsection{Histórico}

O início dos cursos superiores no Brasil foi com a instalação da corte portuguesa no país, quando o rei e a corte portuguesa transferiram-se de Portugal para o Brasil, em 1808 (MASSETTO, 2013).

O processo de criar universidades no Brasil foi de bastante resistência por parte da Coroa de Portugal, que procurava de todas as formas manter o Brasil como colônia, evitando quaisquer possibilidades de desenvolvimento de ideais de independência, e por parte dos brasileiros que não via motivos para se criar uma instituição de ensino superior na colônia. Eles consideravam que o melhor seria que as elites procurassem fazer cursos superiores em Portugal ou em outros países europeus (FAVERO, 2006).

A partir de 1808, no período em que a família real portuguesa esteve no Brasil, foram estabelecidas as primeiras escolas de formação superior, com o intuito de atender aos interesses específicos da corte. Assim, na década de 1820, foram criados os cursos (até hoje tidos como) imperiais: Medicina em São Salvador, Direito em Olinda e Engenharia no Rio de Janeiro. Posteriormente, outros cursos foram criados como os de agronomia, química, desenho técnico, economia, política e arquitetura (FAVERO, XX; JOAQUIM, VILAS BOAS, CARRIERI, 2013)

Todavia, apesar das restrições feitas à criação dessa Universidade, cabe ressaltar que, a Universidade do Rio de Janeiro é a primeira instituição universitária criada legalmente pelo Governo Federal (FAVERO, 2006).

No ano de 1942, criou-se o estágio supervisionado nas instituições, como uma forma de complemento a formação teórica da sala de aula, através da Lei Orgânica do Ensino Industrial e por meio do Decreto-Lei no 4.073/1942. No artigo 47 da Lei tem a definição do estágio " consistirá o estágio em um período de trabalho, realizado por aluno, sob o controle da competente autoridade docente, em estabelecimento industrial". Neste período, o foco do estágio era para ensino técnico, industrial denominado hoje de ensino médio (JOAQUIM, VILAS BOAS, CARRIERI, 2013). 
Na década de 60 e começo da década de 1970, houve uma expansão do número de cursos em universidades públicas. Mas foi em 1968, com a reforma universitária, os investimentos públicos foram direcionados para a pesquisa, favorecendo a implementação de cursos de pósᄀ-graduação. Nestes cursos de pósgraduação teriam que desenvolver pesquisas e formar quadro de docentes nas universidades, mas para formar estes docentes não precisa de nenhum estagio, isso ocorreu até a década de 90.

Em 1999, a CAPES veio obrigar o estágio de docência para todos os bolsistas de mestrado e doutorado sob sua tutela, que até então não existia esta obrigatoriedade de estágio para os alunos da pós-graduação stricto sensu. Com a obrigatoriedade, a instituição acreditava que iria diminuir o impacto causado no ensino superior, uma vez que os alunos da pós-graduação não têm formação em pedagogia (JOAQUIM, VILAS BOAS, CARRIERI, 2013).

\subsection{Estágio docência e mestrado em Desenvolvimento Regional}

\subsubsection{A IES e o Programa}

A instituição de ensino superior (IES), Uni-FACEF Centro Universitário Municipal de Franca, é uma autarquia municipal localizada na cidade de Franca/SP, que oferece diversos cursos para seus alunos. Ela teve início nas suas atividades em 1951, como a Faculdade de Ciências Econômicas e Administrativas de Franca, data da edição do Decreto Federal no 29.377/51, autorizando o seu funcionamento, com o primeiro curso de Economia.

Do início de suas atividades até 1969, o Centro Universitário Municipal de Franca possuía apenas um curso - o de Ciências Econômicas - e um total de, aproximadamente, 100 (cem) alunos. Em 1969, nas instalações novas da Unidade I surgiram novos cursos de Administração e Ciências Contábeis, no período noturno, e consequentemente ampliaram o número de alunos.

Com o decorrer dos anos, o Centro Universitário foi expandindo e atualmente, a instituição tem 3 Unidades, sendo uma Unidade voltada para Ciências Humanas e Sociais, a outra Ciências Exatas e a última é Ciências da Saúde. Atualmente, a instituição oferece, 14 cursos de graduação, em períodos diurno, noturno e integral:

- Administração

- Ciências Contábeis

- Ciência da Computação

- Ciências Econômicas

- Enfermagem

- Engenharia Civil

- Engenharia de Produção 
- Engenharia de Software

- Letras

- Matemática

- Medicina

- Psicologia

- Publicidade e Propaganda

- Sistemas de informação

Além desses, a Instituição de ensino tem programas voltados para a pós-graduação, que oferece cursos de lato sensu (MBA e especialização) e de stricto sensu (mestrado). Dentre os cursos de pós-graduação temos o Programa de Mestrado em Desenvolvimento Regional, na área Interdisciplinar.

Esse programa de Mestrado em Desenvolvimento Regional é um curso de tratamento interdisciplinar do desenvolvimento regional, na área de ciências sociais e humanas, configurado em diversos aspectos como em ações de agentes públicos e privados, voltados para as políticas públicas, e com reflexos no desenvolvimento econômico-social. É curso que trabalha com duas linhas de pesquisas:

Desenvolvimento Social e Políticas Públicas: Enfoca o estudo das ações por agentes públicos e privados com o objetivo de promover o bem-estar social em suas múltiplas dimensões, voltados para as políticas públicas.

Dinâmicas Territoriais e Desenvolvimento Regional: Considera as articulações entre as diversas escalas (local, regional, nacional e global) e propõe estudos sobre as diferentes dinâmicas territoriais. Aborda sobre a contribuição da tecnologia, a composição das estruturas produtivas (setorial e regional), os impactos da globalização e da reestruturação produtiva, os aspectos culturais modeladores de identidades regionais e as questões da saúde, educação e sócio ambientais voltados para o desenvolvimento.

Esse programa tem diversas disciplinas, sendo algumas de caráter obrigatório e outras são eletivas. As eletivas são divididas por linhas de pesquisa. Ao todo são oferecidas 23 disciplinas, sendo 3 de caráter obrigatório que são: Métodos de Pesquisa, Seminários Especiais e Seminários de Pesquisa.

Na disciplina de Seminários de Pesquisa, são abordados assuntos e temas voltados para Didática de Ensino Superior e mostra relatos de vivência dentro do ambiente universitário através de artigos, textos e vídeos. Essa disciplina vai favorecer os discentes para ter um pouco de contato com a realidade do ambiente de docência.

Outro destaque do Programa de Mestrado de Desenvolvimento Regional é com relação ao estágio supervisionado que o mesmo oferece para os discentes, como uma forma de vivencia pratica, e como uma forma de uma atividade curricular. O estágio, para o aluno da Pós-graduação, será parte integrante do 
processo de formação de mestres e doutores e, por isso, representa experiência distinta no âmbito acadêmico.

Além disso, podemos destacar que, na IES Uni-FACEF, os cursos de graduação acolhem de alguma forma os discentes do Programa do Mestrado, para realizar as práticas de estágio supervisionado. Um dos cursos que podemos mencionar é o Curso de Administração que tem turmas no período diurno e noturno, e é $100 \%$ presencial. O Chefe de Departamento do curso é muito receptivo com relação ao estágio de docência, auxilia o discente a entrar em contato com o possível docente para atuar, de forma concomitante durante todo o estágio.

\subsubsection{Regulamento do Estágio Docência}

O estágio de Docência do Ensino Superior do Uni-FACEF, foi instituído em 10 de agosto de 2018, através da Portaria n. 18/2018 que aprova o Regulamento do Estágio de Docência no Programa de Pós-graduação em Desenvolvimento Regional do Uni-FACEF.

Este Regulamento vem definir estágio supervisionado por meio do artigo $2^{\circ}$ como:

é uma atividade opcional, de formação complementar, para os alunos regulares matriculados no PPGDR e consiste em reflexões e vivências das práticas docentes na universidade, com vistas à formação de competências e habilidades de docentes de ensino superior.

Ou seja, o estágio é uma atividade complementar para os alunos participantes do PPGDR, para desenvolver habilidades de docência.

O regulamento complementa dizendo que as atividades do estágio de docência que forem realizadas deverão ter, preferencialmente, relação direta com a linha de pesquisa na qual o estudante está vinculado, e não poderão ser realizadas em disciplinas do programa de pós-graduação stricto sensu.

O estágio pode ser realizado em duas modalidades, segundo artigo $3^{\circ}$. A Modalidade I tem uma carga horária de 15 horas, com mínimo de 10 horas para a execução.

A modalidade II deve ser vinculada a uma disciplina dos cursos de graduação da instituição Uni-FACEF, e será supervisionado pelo docente da disciplina na graduação que, juntamente com a Coordenação do respectivo curso, acompanhará e avaliará as atividades do estagiário. Essa modalidade tem um total de 30 horas sendo que 20 deverão ser presenciais.

A diferença entre uma modalidade e a outra é com relação as atividades. Na modalidade I, são atividades de direção de classe em módulos, oficinas, em cursos superiores da instituição. Já na modalidade II, consiste em atividades de observação, participação e direção de classe. 
Outro aspecto importante do regulamento é a respeito do plano de atividades. O mestrando deve elaborar o plano de atividades, antes do início do estágio identificando qual modalidade irá atuar e quais atividades estarão exercendo durante o período de estágio, e o mesmo deve ser aprovado pelo professor supervisor e pela coordenação do curso.

Por fim, o regulamento nos mostra que o estágio é importante para a formação do docente, uma vez que o mestrando (a) terá que desenvolver diversas ações e atividades tais como: dirigir e participar de atividades em sala de aula, observação do docente supervisor em aula e dos alunos. Auxiliar nos estudos dirigidos e no processo avaliativo; desenvolver aulas para serem ministradas, gerenciamento de diários de classe, planos de aula e domínio de técnicas didáticas, e outras mais.

Essas ações e atividades irão contribuir, de forma intensa na formação dos futuros docentes, trazendo experiências e vivências práticas do dia a dia de um docente em sala de aula e em uma coordenação de curso.

\section{Relato de Experiência}

O trabalho é uma pesquisa bibliográfica em livros, portarias, resoluções, artigos, monografias com dados secundários. Além disso, tem uma abordagem qualitativa que procura compreender a experiência de uma mestranda, do Programa de Mestrado de Desenvolvimento Regional da Instituição Uni-FACEF Franca/SP, através de um relato de experiência. Ela realizou o estágio supervisionado de docência na disciplina de Teoria Geral da Administração do curso de Administração Noturno, $5^{\circ}$ semestre, da própria instituição, no $1^{\circ}$ semestre de 2019, com uma carga horária de 30 horas.

\subsection{Conceito de Relato de Experiência}

Com o objetivo de justificar e dar credibilidade aos dados da presente pesquisa, inicialmente, é realizada uma discussão teórica sobre a abordagem qualitativa, e em seguida, sobre relatos de experiência, a fim de obter subsídios para apresentar e discutir os dados da presente investigação.

Há algumas técnicas de coleta de dados que correspondem à pesquisa qualitativa, tais como a observação participante, história ou relatos de vida, a entrevista individual e coletiva, o teatro da espontaneidade, o jogo dos papeis, análise de conteúdo, entrevista não-diretiva etc., ou qualquer outra que resgate informações subjetivas dos participantes, favorecendo a intervenção dos agentes em sua realidade ou organizando a ação coletiva para transformar as condições problemáticas (CHIZZOTTI, 2001). 
A abordagem qualitativa parte do princípio de que existe uma relação de interdependência entre o mundo real e o sujeito, entre o sujeito e o objeto. Ela diz que o conhecimento não é apenas um conjunto de dados isolados, ligados por uma teoria explicativa; mas que o sujeito como observador é parte fundamental e integrante desse processo de construção do conhecimento, através da interpretação dos fenômenos e dando significado aos mesmos (CHIZZOTTI, 2001). Por isso, a pesquisa qualitativa é uma forma de compreender a experiência que os sujeitos têm, as representações que formam e os conceitos que elaboram. E esses relatos de experiências vão ocupar o centro de referência das análises e interpretações. Além disso, todas as pessoas que participam da pesquisa são reconhecidas como sujeitos que elaboram conhecimentos (CHIZZOTTI, 2001). Há, portanto, uma consideração significativa da participação dos sujeitos na construção do conhecimento.

Em Pádua (2004), os relatos de experiência ou de estágios acadêmicos podem, muitas vezes, ser úteis para a pesquisa como também ser o único recurso para coletar dados, principalmente em situações em que se está construindo o saber cientifico.

A autora complementa, afirmando que esses relatos vêm sendo discutidos no meio acadêmico, e que existem duas posturas com relação a estes instrumentos de estudos (PÁDUA, 2004, p. 77):

- a tradicional, que considera como sua função primordial relatar, narrar, contar os acontecimentos de uma dada intervenção no real, como se pudesse "espelhar" a realidade, um fiel registro do que se passou, que reflete mas não procura repensar a realidade;

- a contemporânea ou moderna, que entende que os relatórios cumpram funções específicas, com o objetivo de transferir um segmento da realidade para um contexto de interpretação cientifica, com seus dados sendo considerados como pontos de partida para o próprio conhecimento de dada realidade, a partir de seu processo.

Nesse sentido, os relatos de experiência de estágio podem oferecer ao pesquisador muitos dados significativos para a compreensão da realidade e, em muitos casos, oferecer elementos para um redimensionamento do projeto. É um documento que tem diversas funções: partindo da teoria, da pratica profissional e do método (PÁDUA, 2004).

\subsection{A experiência}

O estágio de docência é uma atividade curricular para alunos da PósGraduação stricto sensu (mestrado e doutorado), sendo definida como a participação do (a) aluno/a em atividades de ensino na instituição, sob a supervisão de seu orientador. 
Ele tem como objetivo auxiliar o/a professor/a na elaboração e apresentação das aulas, na preparação de material didático e no desenvolvimento burocrático da disciplina ao longo do semestre. O discente tem que acompanhar o docente, desde o seu planejamento até a execução das atividades, bem como, desenvolver a prática docente, a fim de obter uma reflexão crítica em torno da atividade de lecionar.

Ao realizar esse processo, estará contribuindo para a vivência da relação professor-aluno no contexto da sala de aula, promovendo o desenvolvimento de práticas didáticas junto às atividades de ensino de graduação, além de mostrar a importância da docência na formação profissional e por fim, promovendo a inserção no contexto do mercado de trabalho para conhecimento da realidade.

A experiência com o estágio docência permitiu à mestranda ter 0 primeiro contato com a docência no ensino superior, proporcionando a ela o compartilhamento de conhecimentos, informações e práticas de suas experiências profissionais, assim como da experiência acadêmica com os discentes da graduação e com os professores responsáveis pelo componente curricular.

A mestranda realizou o estágio de docência no curso de Administração período noturno na Instituição de Ensino Superior Uni-FACEF - Centro Universitário Municipal de Franca, na disciplina de Teoria Geral da Administração, sob a supervisão de um docente da disciplina, no período de 01 de fevereiro de 2019 a 30 de junho de 2019.

Neste período de estagio, gerou-se diversos questionamentos ao preparar e planejar aulas, e solucionou-se simultaneamente diversas dúvidas que existiam pela mestranda anterior a vivência.

No início, a mestranda ministrou algumas aulas, e nesse processo envolveu diversas atividades como: planejar, preparar e executar todo o processo de como dar aula, como dirigir uma classe, elaborar um cronograma, preparar conteúdo e atividades extra-classe para os alunos. E esse ciclo de construir a aula foi marcado por muitos questionamentos como: Como abordar o assunto com questões pedagógicas que pudessem refletir situações reais e/ou cotidianas? Qual a maneira ideal de abordar o tema, de modo que os discentes interagissem e sentissem interesse em participar da aula? Quais os pontos deveriam ser enfatizados? Qual a melhor maneira de distribuir os tópicos que tem que ser abordados ao longo do bimestre, de modo que não fique muito apertado ou com muita folga, seja equilibrado? Quais atividades extra que poderiam ser aplicadas e quando aplicar?. A partir desses questionamentos, a mestranda foi trocando ideias com outros docentes e com os próprios alunos para adequar ao melhor modo.

Outro fato que se observou, após a primeira aula, é que seria necessário estimular ainda mais, a participação dos discentes, de maneira que a aula fosse mais dinâmica e, por conseguinte alcançasse o seu objetivo, a construção do conhecimento. Além disso, a mestranda teria que ter mais recursos para ser 
trabalhado em aula, como atividades-extra em grupo para possíveis debates e ministrar melhor o tempo de aula para atribuições das atividades.

A partir desse primeiro contato, houve evoluções nas aulas seguintes, tanto dos alunos como da mestranda, as aulas tornaram-se mais participativas e dinâmicas, os alunos com atitudes mais proativa, questionando e expondo as suas opiniões sobre os temas apresentados.

Outro ponto relevante a se comentar é que a mestranda, durante alguns períodos, tinha as mesmas responsabilidades que o docente titular tem em uma sala de aula, como fazer chamada de presença, avaliar as atividades aplicadas em sala de aula, ter que chamar a atenção de alunos quando estão interrompendo, ou atrapalhando a atividade em sala de aula, entre outras.

Houve o período de avaliação bimestral, em que o docente titular sugeriu a mestranda para que auxiliasse na elaboração da avaliação para ser aplicado aos alunos da graduação. Surgiram outros questionamentos: Que tipo de pergunta gostaria de colocar na prova? Questões abertas ou testes? Ou os dois? Quais são pontos principais a cobrar na avaliação? Quantas questões irão compor a prova? Entre outras. Mas tudo foi solucionado, com o auxílio da docente na escolha das melhores questões.

Além da participação na elaboração das avaliações bimestrais, a mestranda teve participação ativa na aplicação da avaliação. Foi uma experiência também bem diferente, pelo simples fato de ter que observar os alunos realizarem a prova sem deixarem colar. A respeito das correções de prova foram realizadas pela docente e conferida pela mestranda.

Neste processo, foi possível compreender o quanto é complexo avaliar e, ainda, que a avaliação está além do papel da prova, esta nas relações construídas em sala de aula, no comportamento dos alunos representam muito do processo avaliativo, demonstrando se os mesmos conseguiram aprender os conteúdos ministrados.

Por diversas vezes, durante o período de estágio, o docente titular deu dicas e trocou saberes, informações, a respeito da melhor maneira para se ministrar aulas e interagir com a sala de aula, de modo que não fique cansativo. Nesta troca, foram compartilhados vários tipos de saberes, pois a atividade docente é complexa e envolve não apenas os saberes técnicos, como também saberes afetivos, éticos, sociais, pedagógicos, psicológicos.

O que pode dizer que no estágio de docência, no ambiente de sala de aula, através da experiência cotidiana do docente na sala de aula que se desenvolve a aprendizagem da docência que, através dele se adquire muito aprendizado, muitas coisas boas e enriquecedoras. É uma oportunidade única que se leva para a vida e que, de alguma forma, transforma aquela sensação de incerteza e insegurança do discente em algo que realmente vale a pena a se seguir para carreira profissional, 
mesmo diante de algumas dificuldades enfrentadas em sala de aula, que tem em qualquer ambiente de trabalho.

\section{CONSIDERAÇÕES FINAIS}

Este trabalho teve como objetivo descrever as atividades planejadas e desenvolvidas, em estágio docência, por uma mestranda da área de desenvolvimento regional, no curso de Administração de uma Instituição de Ensino Superior pública municipal, a fim de estabelecer parâmetros de formação de professores para o ensino superior e avaliar as práticas da atividade como forma de contribuição para a formação de capital humano no referido segmento.

Pode-se vivenciar a questão técnica do planejamento das aulas, do cumprimento de plano de ensino. Vivenciou-se a seleção de conteúdo, de metodologia e de avaliação, seja nas aulas, seja no momento de avaliações bimestrais formais. Os objetivos e as competências a serem desenvolvidas, com os estudantes, nortearam as práticas e a didática da estagiária.

Para além disso, constatou-se a necessidade de olhar para as questões humanas, na relação interpessoal. Houve trocas com o orientador da pesquisa, com o supervisor da disciplina e com os estudantes. Nesse sentido, 0 compartilhamento e as negociações de convivência escolar foram significativos. Destaca-se a necessidade de relevar o aspecto humano.

Por fim, o âmbito social também pode ser destacado, uma vez que o conhecimento produzido levou em conta as demandas da área e da formação dos estudantes.

Diante do relato de experiência, pode-se dizer que a experiência no estágio de docência foi enriquecedora e de grande valia e importância na formação profissional de docente para o ensino superior para a mestranda, propiciando o desenvolvimento de competências técnicas-cientifico, pedagógicas e práticas.

\section{REFERÊNCIAS}

BRASIL. Ministério da Educação e Cultura. Lei n. 9.394, de 20 de dezembro de 1996, Estabelece as diretrizes e bases da educação nacional. Brasília: MEC/SEF, 1996.

BRASIL. Ministério da Educação. Resolução no 7, de 11 de dezembro de 2017. Estabelece normas para o funcionamento de cursos de pós-graduação stricto sensu. Diário Oficial da União: seção 1, Brasília, DF, p. 21,12 de dezembro de 2017.

BRASIL. Senado Federal. Parecer CFE no 977/65, aprovado em 3 dez. 1965. Revista Brasileira de Educação. n. 30. pp. 162-173. set. /out. /nov. /dez. 2005. 
CHIZZOTTI, Antônio. Pesquisa em ciências humanas e sociais. 5. ed. São Paulo: Cortez, 2001. 164 p.

CURY, Carlos R. J. Quadragésimo ano do parecer CFE n‥ 977/65. Revista Brasileira de Educação. n. 30. pp. 7-20. set. /out. /nov. /dez. 2005.

FÁVERO, M. L. A. A Universidade no Brasil: das origens à Reforma Universitária de 1968. Educar, Curitiba, n. 28, p. 17-36, 2006.

JOAQUIM, N. de F.; VILAS BOAS, A. A.; CARRIERI, A. de P.. Estágio docente: formação profissional...Educ. Pesqui., São Paulo, v. 39, n. 2, p. 351-365, abr./jun. 2013.

PÁDUA, Elisabete Matallo Marchesini de. Metodologia da pesquisa: Abordagem teórico-prática. 10 ed. Campinas: Papirus, 2004.124 p.

PERRENOUD, Philippe. A prática reflexiva no oficio de professor: profissionalização e razão pedagógica. Tradução de Cláudia Schilling. Porto Alegre: Artmed, 2002. 232 p.

SILVA, José Antônio Camargo. Estudando as novas tecnologias na educação infantil. 4. ed. São Paulo: Contexto, 2000. 324 p.

MASETTO, Marcos T. (Org.). Docência na universidade. Campinas: Papirus, 2013.128 p.

VASCONCELOS, Maria Lucia Marcondes Carvalho. A formação do professor do ensino superior. 2 ed. São Paulo: Pioneira, 2000. 74 p.

VEIGA, IIma Passos Alencastro. A aventura de formar professores. Campinas: Papirus, $2009.100 \mathrm{p}$. 


\title{
PRODUÇÃO DO CONHECIMENTO EM REDE: Um estudo junto a professores da rede pública
}

\author{
VAGULA, Edilaine Vagula \\ Doutora em Educação - UEL \\ edilainevagula@yahoo.com \\ NASCIMENTO, Mari Clair Moro \\ Doutora em Educação - UEL \\ mariclairmoro@hotmail.com \\ OLIVEIRA, Anelise Martinelli Borges \\ Doutora em Educação - UFTM \\ anelisemartinelli@hotmail.com
}

\section{INTRODUÇÃO}

A pesquisa relata uma experiência de formação de professores em uma escola estadual do estado do Paraná, com o objetivo geral de levar os professores a pesquisar e produzir recursos educacionais abertos, para disponibilizá-los, de forma livre e aberta, analisando suas possibilidades na educação básica; o objetivo específico foi refletir sobre a aprendizagem colaborativa e as contribuições do Recurso Educacional Aberto - REA, verificando seu potencial didático e comunicativo.

A competência pedagógica para o uso da tecnologia em sala de aula, envolve mobilizar situações didáticas que possibilitem a construção do conhecimento. Considerando esta proposição, podemos levantar como hipótese o fato de que nem sempre dispomos de um preparo satisfatório que conduza à ação, e, no caso da inserção dos Recursos Educacionais Abertos REAs em sala de aula, as oportunidades de transformar este conhecimento em ação são reduzidas ao espaço/tempo da utilização do laboratório de informática. A intenção do trabalho era foi possibilitar a produção de REAs pelos professores participantes das oficinais pedagógicas, encorajá-los a publicar e a compartilhar, possibilitando a geração de uma nova cultura, na qual os professores são produtores de conhecimento em rede.

Traçando as grandes linhas do estudo, nosso maior desafio era disponibilizar ao professor a oportunidade de mudar a sua prática de um foco individualista para colaborativo, construindo REAs criativos e ricos em conteúdo, adaptados à realidade, rompendo com velhos paradigmas. 
Com as oficinas pedagógicas foi possível estabelecer relações entre a construção do conhecimento, o uso do Recurso Educacional Aberto REA e a escola, permitindo aos professores a compreensão da dimensão conceitual e o domínio de programas que permitem a sua criação. Sentimos que seria inevitável confrontar tais recursos com a insegurança de muitos, a sensação de despreparo, mas, conscientes disso, incentivamos os participantes a propor e desenvolver REAs voltados para sua área de atuação. Tal momento foi relevante para os professores, pois estes tiveram a oportunidade de inserir a tecnologia em suas aulas, contar com recursos educacionais inovadores, utilizar as ferramentas da WEB $2.0 \mathrm{em}$ sala de aula e renovar suas práticas pedagógicas. É importante ressaltar que, durante sua realização, percebiam-se múltiplos olhares sobre a tecnologia e, com base no recorte que realizamos, buscamos significados e sentidos sobre os REAs. A oficina foi realizada na modalidade semipresencial, com carga horária de 40 horas, sendo $20 \mathrm{~h}$ para cinco encontros presenciais, desenvolvidos no Laboratório de Informática, 10 horas a distância, período em que se deveria realizar a leitura do caderno sobre REA e elaborar um plano de aula, e, finalmente, 10 horas para desenvolvimento do trabalho em sala de aula, junto aos alunos. Os pressupostos teóricos que direcionavam o desenvolvimento do curso eram os princípios colaborativos na educação.

A proposta foi organizada por meio do trabalho teórico-prático com atividades diversas. Com o feedback da atividade realizada na oficina, foi possível estabelecer as contribuições desta prática para a aprendizagem dos alunos e ampliar o significado do movimento REA, vivenciando um processo de construção coletiva.

\section{METODOLOGIA}

A proposta, que possibilitou a interação entre pesquisador e participantes do estudo, teve como propósito transformações na atuação destes profissionais, face aos objetivos propostos, com o intuito de produzir conhecimentos que pudessem transformar sua prática, reestruturando processos formativos, a partir do uso das tecnologias. Assim, foi possível coletar informações sobre nosso problema de pesquisa, verificar no campo como se dão as questões teóricas, levando os sujeitos a atuarem de forma participativa, no seu próprio ambiente de trabalho, envolvendo-os em um processo de criação e compromisso com a formação dos educandos. 
No desenvolvimento do trabalho sobre REA, utilizamos o Grupo Focal para coletar dados junto aos professores, analisando-os por meio da técnica do Discurso do Sujeito Coletivo, refletindo sobre os dizeres do grupo, suas vivências e percepções sobre o REA. Tal técnica permitiu não só compreender as representações sobre o uso da tecnologia e do REA em sala de aula, como também o trabalho desenvolvido, abrindo diversas possibilidades sobre o tema em questão.

Para organizar os dados qualitativos, compomos um discurso sobre o estudo, agregando os sentidos expressos pelos participantes em um único discurso, possibilitando a organização dos dados qualitativos sem limitálos a quantidades. Desta forma, após a análise dos dados coletados verbalmente, foram selecionadas as principais contribuições e suas expressões-chave, o que proporcionou uma síntese dos dados coletivos, como se fosse um único participante, assim "O conteúdo deste depoimento síntese é editado para constituir o produto final que é o discurso do sujeito coletivo, ou seja, uma opinião coletiva de uma pessoa coletiva". (FIGUEIREDO, 2013, p. 133). Seu uso propiciou a análise das transformações significativas na realidade, pela percepção dos pensamentos, valores, crenças e dizeres de participantes. Para Figueiredo (2013, p. 130)

O Discurso do Sujeito Coletivo - DSC é uma técnica de tabulação e organização de dados qualitativos, desenvolvido por Lefevre e Lefevre no fim da década de 90, e tem como fundamento a teoria da Representação Social. O DSC é um discurso-síntese elaborado com partes de discursos de sentido semelhante, por meio de procedimentos sistemáticos e padronizados.

Considerando, então, a possibilidade de compreender os conhecimentos compartilhados e construídos no grupo, a influência dos participantes no processo de colaboração, "o grupo focal é um ambiente mais natural e holístico em que os participantes levam em consideração os pontos de vista dos outros na formulação de suas respostas e comentam suas próprias experiências e as dos outros" (GOMES: TELLES; ROBALLO, 2009, p. 857). Esta situação descrita pelos autores foi constante durante todo 0 trabalho. Os comportamentos dos participantes foram observados, sem perder de vista os objetivos do estudo.

Os grupos focais foram videogravados e a câmera de vídeo posicionada de maneira que não focalizasse nenhum participante. Previamente foram informados sobre os objetivos da pesquisa e acerca do Termo de Consentimento Livre e Esclarecido, que os resguardaria quanto ao uso das informações. Após o consentimento dos participantes, os grupos focais foram conduzidos pela pesquisadora em três momentos distintos, que foram gravados e transcritos, registrando-se minuto a minuto as contribuições dos 
participantes. O grupo selecionado apresentava características em comum, como, por exemplo, serem professores do ensino fundamental e médio, atuarem na educação básica e demonstrarem muito interesse em conhecer mais sobre tecnologias educacionais, em especial sobre os REAs. Com idades entre 24 e 63 anos, 15 destes 16 participantes eram do sexo feminino.

Contávamos com um grupo de 16 professores experientes e com muitas vivências para serem compartilhadas, em sua maioria, concluíram o Ensino Superior no município de Londrina, em IES pública e cinco em instituições particulares, sendo três no município de Londrina e dois em outras localidades, registrando-se que a maioria (11/16) o fez em universidade pública, mais especificamente na UEL. O período de conclusão deste nível de ensino situou-se, em sua maioria, entre 1980 a 1989, isto é, a maioria $(n=09)$ havia concluído a graduação, há menos de 30 anos, sendo que prevaleceu 0 período de 1980-1989 $(n=9)$ e os demais, 1990-1999 ( $n=3), 2000-2009(n=3)$ e um participante não informou o ano de conclusão. Todos os participantes, à época da coleta de informações, já haviam concluído a sua pós-graduação

\section{A EXPERIÊNCIA COM OS REAs NAS OFICINAS PEDAGÓGICAS}

As investigações atuais de alguns pesquisadores como Capra (2004) e Castells (1999) e outros como Pretto (2012) e Okada (2011) que se dedicam ao REA têm apontado o surgimento de novas possibilidades com o trabalho educativo desenvolvido por meio das redes, contribuindo, assim, para a formação do aluno, que, neste tipo de ensino, é considerado agente de sua própria aprendizagem. Aliado a isso, evidencia-se a necessidade de trabalhar de forma flexível e considerar que o termo educação em rede está muito presente nos dias atuais, possibilitando um aprendizado em conjunto, tendo como diferencial o respeito aos diferentes ritmos de aprendizagem e espaçotempo.

A educação aberta colaborativa possibilita a construção de conhecimentos gerados na rede, democratizando o acesso, favorecendo compartilhamento e reconstrução do conhecimento de forma colaborativa, por meio da qual, os atores tornam-se mais autônomos em relação a esta construção, gerando práticas transformadoras.

[...] aprendizes que sabem como usar recursos abertos e redes colaborativas para aprender são aprendizes comprometidos com seu próprio processo de aprender, capazes de fazer suas próprias escolhas, ampliar seus contatos, compartilhar reflexões e experiências, obter e avaliar feedback, investigar mais ao seu redor e 
ir em busca de aprender não só "o quê" e "onde", mas também, "como" e "com quem" (OKADA et al, 2010 apud OKADA, 2011, p. 10).

Com os REAs, o professor pode atender as progressivas fases de ensino, e criar condições para que os alunos se apropriem do conhecimento, assim acreditar que o aluno pode ser capaz de aprender. É necessário construir um novo discurso didático. Nesse sentido, Behrens (2007, p. 57) afirma que:

\begin{abstract}
A visão inovadora tem como pilar sustentador o diálogo, a problematização e as ações compartilhadas (o professor) precisa viabilizar um processo educativo que garanta a prática docente dialogada e problematizadora. Para tanto, o professor necessita inovar seu modo de agir e pensar e ter presente que, para gerar mudanças, deve considerar também a utilização das ferramentas disponíveis na rede informatizada.
\end{abstract}

Em consonância com esta dimensão conceitual, Torres (2007) caracteriza a aprendizagem colaborativa como uma metodologia, organizada por meio do trabalho em grupo, que possibilita aos alunos apropriarem-se de conhecimentos de forma coletiva, em um processo dialético de troca de saberes. Deste modo, os grupos compartilham do mesmo objetivo, as relações deixam de ser hierarquizadas, práticas conservadoras cedem lugar a colaboração, em um processo ativo de construção do conhecimento. Neste contexto, o papel de cada participante é organizado no grupo, as decisões são compartilhadas e, como facilitadores deste processo, os professores estimulam nos alunos o desenvolvimento da corresponsabilidade pelo desempenho dos demais estudantes.

Em todos os momentos do desenvolvimento das oficinas pedagógicas, sentimos que os professores estavam motivados e com muitas expectativas. Isso talvez pelo tema bastante atrativo e também pela possibilidade de se obter a certificação, que poderia contar para elevação no quadro de carreira do estado. Ao iniciarmos a oficina nos deparamos com problemas em relação à conexão. O trabalho iniciou-se com a apresentação dos objetivos e do "Termo de Consentimento Livre e esclarecido", aos professores, que já haviam sido convidados a participar voluntariamente do estudo. Em seguida, com a utilização de vídeos e podcast, foi feita, de forma dinâmica, uma explanação sobre REA, recurso que consiste em gravações de áudio em MP3 disponibilizadas em websites. Os participantes apropriaram-se dos conceitos, do processo de criação e licenças, ao mesmo tempo em que valorizaram seu potencial pedagógico.

Foi possível verificar, que, em sua maioria, o conhecimento sobre tecnologia era básico, pois, além de apresentarem muitas dificuldades, desconheciam o uso de programas mais complexos. Após o momento de 
aprofundamento teórico, realizamos o grupo focal, que foi desenvolvido no Laboratório de Informática, mas, ficou evidente que, apesar de estarem à frente ao computador, focalizaram sua atenção apenas nas discussões realizadas. $\mathrm{Na}$ continuidade do encontro e, conforme solicitação do grupo, primeiramente, priorizou-se a captura de vídeos do Youtube e as diferentes possibilidades de conversão, com a intenção de localizar, em repositórios, material que pudesse atender ao conteúdo proposto pelo professor, a partir dos seus objetivos e necessidades. Desde o início, era possível perceber que os professores valorizavam o fato de poderem utilizar materiais organizados em sua trajetória profissional, guardados no formato impresso ou em seus computadores, assim como a possibilidade de compartilhar e colaborar com outros professores. Nos encontros posteriores, usaram o Windows Movie Maker, e, embora tenham considerado fácil o acesso, afirmaram que teriam dificuldades no momento em que fossem produzir os seus vídeos.

Cortelazzo (2004, p. 258), em estudo realizado sobre tecnologias junto a professores, constatou que muitos deles "continuam a trabalhar apenas no âmbito do cognitivo, enquanto eles próprios e seus alunos são atingidos pela comunicação midiática que seduz pelos ouvidos, pelos olhos e pela pele". Em nosso caso, o desafio estava posto: levar os professores a fazerem uso das mídias eletrônicas junto aos seus alunos. Devido aos problemas relacionados à velocidade da conexão com a internet, comprometeram-se a definir um tema e baixar vídeos e imagens relacionados ao conteúdo proposto em seus computadores, tomando o cuidado para não utilizar a versão offline. Outro compromisso assumido foi buscar, em seus arquivos, materiais que pudessem ser úteis à sua proposta.

Segundo Morais; Ribeiro: e Amiel (2011, p. 108 16) Versões "offline" ou "locais" de REA são recursos que podem ser encontrados e usados sem a necessidade de conexão com a Internet. Muitas escolas públicas ainda sofrem com problemas de conexão à Internet e acesso a computadores. Para professores que enfrentam esses problemas, as versões "offline" (locais) de REA são muito úteis e valiosas.

Em nosso estudo, os professores foram orientados a capturar imagens da internet e fotografar. O programa indicado para o trabalho com a imagem foi o Picassa e, para a criação do REA, foi escolhido o Windows Movie Maker. Após o trabalho com o domínio do programa, foi possível o processo de criação com a inserção de imagens, texto, captura e reedição de vídeos do Youtube. O programa Audacity foi utilizado para a inserção das músicas no formato MP3. Muitos professores fizeram o uso do remix, realizando alterações no material encontrado no Youtube, adequando-o à sua realidade. Nos encontros seguintes, disponibilizamos diversos sites para pesquisa e 0 
processo de criação envolveu a utilização de recursos que alguns participantes tinham a sua disposição; outros criaram um material completamente novo. Ao compor seu REA, valeram-se de adaptações, para atender à realidade na qual o recurso seria utilizado.

Como era importante analisar o impacto do trabalho desenvolvido nas oficinas, solicitamos que os participantes avaliassem por meio do questionário a oportunidade de entrar em contato com a produção e utilização do REA. Os depoimentos demonstraram que todos, no momento da coleta, consideraram uma excelente oportunidade de ampliar conhecimentos e oferecer apoio a professores da educação básica, para que, compartilhando o REA, o mesmo estivesse disponível para ser utilizado em outros contextos. Nesse sentido, discutimos sobre o formato a ser disponibilizado na rede, um "formato mais comum (por exemplo, um arquivo de vídeo MPEG ou MP4), seria fácil modificá-lo em um computador que tenha o software adequado." (CADERNO REA, p. 6).

Aquele sentimento inicial de incapacidade diante da tecnologia foise modificando, os professores perceberam que, para produzirem REAs, não era necessário um domínio elevado de ferramentas tecnológicas e foram dominando e se familiarizando com os termos específicos voltados para o REA. "Criar recursos educacionais abertos, seja para alunos, para outros professores ou mesmo para crescimento pessoal, já é em si uma experiência de aprendizado, principalmente sobre conceitos importantes relacionados à Internet e a tecnologias da informação e comunicação (TIC)". (CADERNO REA, p. 11). Após a finalização do REA, foi necessário inserir uma licença e adotarmos um padrão internacional utilizando o Creative Commons.

A opção foi por uma licença aberta e sem restrições, pois o objetivo era tornar o recurso acessível a outros educadores, hospedando 0 REA no Youtube. Os professores sentiram dificuldade em compreender as licenças, mas salientamos que, com as licenças/termos de uso para cada recurso de forma aberta, o material disponibilizado contribui para uso, reuso, adaptação ou remix. Assim, após conhecerem alguns repositórios, decidiram pelo Youtube, pelo fato de ser muito conhecido e utilizado por quase todos os professores da educação básica. Com o licenciamento aberto do material, o grupo vislumbrou que outros professores que atuam na mesma disciplina e nível de ensino poderiam usufruir livremente do recurso, inserir novos conteúdos e realizar combinações.

Sobre a produção de REA, é importante considerar o que concluíram Mercado; Silva e Gracindo (2008, p. 118), em estudo desenvolvido sobre a utilização didática do REA: 
É considerada fundamental a reutilização em uma situação em que ocorre a diversidade de indivíduos que vão utilizar um objeto. Para tanto, são imprescindíveis algumas adaptações às necessidades do usuário (professo/aluno), sendo atendidas a partir das situações didáticas norteadas pelas diversas adequações decorrentes da evolução do software. (MERCADO; SILVA; GRACINDO, 2008, p. 117).

Pela análise dos REAs produzidos pelos professores, é possível identificar que apresentam tais características de reuso, já que, em sua maioria, podem ser empregados em mais de uma área do conhecimento e em vários anos do ensino fundamental ou médio, podendo ser adaptados a diversas finalidades. Além disso, os professores elaboraram, como atividade a distância, um plano de aula, com objetivos e estratégias de ensino para compor o material, fizeram as devidas referências dos autores utilizados e perceberam que todo REA precisa ser adaptado à realidade da turma e estar direcionado para os objetivos estabelecidos.

Analisando-se a produção dos REAs e sua respectiva postagem, verificamos que apenas um participante dispunha de uma conta no Youtube. Os demais não sabiam criar; alguns até tentaram fazer em casa, mas sentiram dificuldades e a necessidade de realizar tarefas colaborativas despertou trocas e acolhimento das dificuldades entre os participantes. Como pesquisadores, acompanhamos as interações comunicativas, auxiliamos passo a passo a criação da conta e a postagem do material. No decorrer da proposta, o grupo foi apresentando suas ideias sem receio de errar, percebendo-nos como colaboradores, atribuindo sentidos à sua produção, possibilitando o alcance dos objetivos propostos.

Ao iniciar o trabalho com o grupo focal, apresentamos o problema da pesquisa e utilizamos um roteiro semiestruturado para orientar a discussão e deixar claros os objetivos do estudo. Nesta etapa, nossa intenção era coletar dados sobre o conceito de REA, as ideias e representações presentes nos enunciados dos participantes sobre a tecnologia, a fim de analisar elementos que pudessem tornar possível a compreensão do seu fazer cotidiano e de suas escolhas quanto às metodologias e recursos.

O momento foi de troca de experiências em relação a práticas cotidianas, de identificação de consenso em relação a algumas ações desenvolvidas e de promoção de práticas colaborativas e possibilidade de encontro dos professores com a tecnologia. O trabalho, inspirado em técnicas de entrevistas não direcionadas, permitiu a interação entre os professores colaboradores, explicitando diferentes visões acerca do objeto de investigação. Os registros dos dizeres em vídeo e as transcrições realizadas contribuíram para maior familiaridade em relação ao tema em estudo, o que favoreceu sua interpretação. 
Cumpre reiterar que, aos poucos, o sentimento de insegurança em relação à tecnologia, o medo do novo foram cedendo lugar à análise da tecnologia como possibilidade de mudança, de ferramenta de mediação que possibilita o encontro do aluno com o objeto de conhecimento, gerando espaços colaborativos.

Quanto aos sentidos dos benefícios do trabalho com REA, os participantes valorizaram a oportunidade de trabalhar com metodologias e recursos inovadores que contribuam com a prática cotidiana e o acesso a conteúdos atualizados em sua área de atuação, sendo possível usar, criar, reutilizar, adaptar e compartilhar.

Durante o desenvolvimento da oficina, porém, foi possível constatar também a empolgação de muitos por sentirem-se capazes de usar, criar, reutilizar, adaptar e compartilhar seus próprios recursos. Torres et al. (2008), ao estudar a formação continuada on-line para professores, afirmou que "a formação contínua do professor precisa incorporar possibilidades de reorganizar a prática pedagógica incluindo as novas tecnologias da informação e da comunicação, no sentido de ampliar os recursos de aprendizagem". (2008, p.435).

Sentindo-se capazes desta reorganização, muitos foram impulsionados a desenvolver o processo de criação do REA com seus próprios alunos, pois "O grande salto qualitativo que se espera do professor é a utilização pedagógica dos recursos de mídias dentro das disciplinas, ou seja, a opção pelo laboratório para ensinar e para aprender os conhecimentos específicos das disciplinas" (TORRES, et al., 2008, p. 435).

A escola necessita considerar a habilidade de reorganizar 0 conhecimento, de pensar, instituindo a transdisciplinaridade, provocando a interpretação, a argumentação, a complexidade do conhecimento e a cultura humana e científica. É necessário um pensamento que "compreenda que o conhecimento das partes depende do conhecimento do todo, e que o conhecimento do todo, depende do conhecimento das partes" (MORIN, 2011, p. 88).

Embora a estrutura da escola não atenda às necessidades dos professores quanto ao espaço físico do laboratório, TV Pendrive e internet, a resistência inicial frente a estas dificuldades conclamou professores e alunos a serem protagonistas de sua própria história e a desenvolver postura investigativa e colaborativa, que resultou na remoção das barreiras e na transformação das práticas escolares, visando à construção de espaços colaborativos. 


\section{CONSIDERAÇÕES FINAIS}

Trabalhar com os recursos educacionais abertos em um paradigma inovador contribui para o desenvolvimento do pensamento complexo, segundo o qual os conteúdos devem ser ligados à experiência dos alunos, deslocando o foco do conteúdo para a maneira de se aprender.

No que diz respeito ao trabalho com o REA, este representa aprendizagem colaborativa adequada ao contexto escolar da educação básica, que desenvolve competências e habilidades com o uso da WEB 2.0, levando o aluno a posicionar-se criticamente diante dos conteúdos escolares através da interação com seus pares e a problematização. O conhecimento, então, passa a ser de construção coletiva. A intenção do estudo foi de investigar possibilidades de colaboração na prática docente, capacitando os professores a criar, recriar e reutilizar REA e analisar os materiais já disponibilizados em repositórios. É preciso, ainda, destacar que, ao elaborar o REA para ser utilizado na educação básica, é importante que o docente tenha como princípios clareza, objetividade e contextualização de conhecimentos para que os objetivos propostos sejam atingidos. Além disso, o material precisa ser preparado com conteúdo significativo e acessível a todos os alunos, o que favorece a interatividade.

Partindo da experiência desenvolvida na escola pública com o REA, foi constada a necessidade de condições propícias de trabalho, para que o professor possa ousar e enveredar pelos caminhos da tecnologia. Nesse sentido, a ampliação do laboratório, no que se refere ao espaço físico, a aquisição de mais computadores e também a instalação de internet mais rápida, podem incentivar os professores a produzirem conhecimento, compartilhar REAs e trocar experiências, através de um processo de coautoria, gerado pela colaboração. Os resultados apontam para a necessidade de redefinição quanto à utilização de metodologias inovadoras, demonstrando sua validade quanto à produção do conhecimento e o estabelecimento de práticas de colaboração.

Acreditamos que a contribuição mais relevante desta pesquisa foi o que ela revelou as contribuições do REA para a construção colaborativa do conhecimento, através do conjunto de relatos verbais foi possível repensar a prática pedagógica, comprovar-se a necessidade de atuar com mais segurança diante da tecnologia, aliada à necessidade de inovar, e utilizar novos procedimentos de ensino. Além disso, pudemos constatar que a configuração do novo propiciou a redescoberta de formas de construir conhecimento, tendo 
a tecnologia como ponto-chave para integrar novas possibilidades, certamente a formação dos professores é o caminho para a construção de um novo saberfazer, para a mudança paradigmática.

Integrando diferentes mídias em sua metodologia o professor está imerso na cultura digital e passa a ser produtor de saberes. Formando uma rede e conhecimentos, é possível formar um aluno mais reflexivo, autônomo, crítico e participante. É importante que o professor compreenda a sua prática e integre diferentes interfaces, cada vez mais encontramos em sala alunos que utilizam a tecnologia em seu cotidiano e com seu apoio o professor pode fazer bom uso da tecnologia de forma criativa e inovadora.

Os participantes reconheceram que as possibilidades de utilização na escola são muitas, podem elaborar seus próprios materiais, remixar, usar, compartilhar e aprimorar os vínculos com outros profissionais desenvolvendo práticas colaborativas, o mais importante foi a valorização do REA como produção do aluno, com a orientação do professor e a disseminação do conhecimento.

Como se vê, os caminhos do conhecimento podem apontar para novas formas de ensinar, com perspectivas colaborativas entre seus pares, considerando-se que modificar implica analisar o "estar juntos" em experiências formadoras, atribuir novos sentidos à prática, examinando e vencendo obstáculos, conferindo autonomia para organizar o cotidiano acadêmico em função da tecnologia. Neste sentido, as oficinas contribuíram para desvelar práticas conservadoras, romper com costumes tradicionais, fazer predominar 0 processo de cocriação. Tal resultado foi enriquecido pelo desejo do grupo de buscar novos conhecimentos, de compartilhar, de colaborar. Isso, aliado à mediação da comunicação, possibilitou a comprovação de que os Recursos Educacionais Abertos ampliam a colaboração entre as pessoas.

A despeito de alguns obstáculos apontados e, sem a pretensão de estarmos esgotando todas as possibilidades do REA, é importante dizer que os professores participantes valorizaram muito este espaço de formação.

\section{REFERÊNCIAS}

BEHRENS, Marilda Aparecida. O paradigma da complexidade na formação e no desenvolvimento profissional de professores universitários. Educação. Porto Alegre, ano 30, v. 63, n. 3, p. 439-455, set./dez. 2007. Disponível em: http://revistaseletronicas.pucrs.br/ojs/index.php/faced/article/viewFile/27. Acesso em 20 Agos. 2019. 
FORMAÇÃO DOCENTE: UM PROCESSO EM CONTÍNUA CONSTRUÇÃO DE CONHECIMENTOS ISBN: 978-85-5453030-3

CORTELAZZO, Iolanda Bueno de. Camargo. Ambientes de Aprendizagem otimizados pela Tecnologia Educacional In: XII Encontro Nacional de Didática e Prática de Ensino ENDIPE, 2004, Curitiba. Conhecimento Local e Conhecimento Universal: Diversidade, Mídias e Tecnologias na Educação. V. 2. Curitiba: Champagnat, 2004. p.255-265.

CAPRA, Fritjof. A Teia da Vida: uma nova compreensão Científica dos sistemas vivos. $9^{\underline{a}}$ ed. Trad. Newton Roberval Eichemberg. São Paulo, SP: Editora Pensamento Cultrix Ltda, 2004. 256p.

CASTELLS, Manuel. A Era da Informação: Economia, Sociedade e Cultura. A Sociedade em Rede. Vol. 1. 5. ed. São Paulo: Paz e Terra, 1999. 698p.

FIGUEIREDO, Marília Z. A; CHIARI, Brasília M.; GOULART, Bárbara N. G. de. Discurso do Sujeito Coletivo: uma breve introdução à ferramenta de pesquisa qualiquantitativa. Revista Distúrbios da Comunicação. São Paulo, n. 25, Vol. 1. Abril, 2013. p.129-136.

GATTI, Bernadete Angelina. Grupo focal na pesquisa em ciências sociais e humanas. Brasília: Líber Livro, 2005. 77p.

GOMES, Vera Lúcia de Oliveira; TELLES, Kátia da Silva; ROBALLO, Evelyn de Castro. Grupo focal e discurso do sujeito coletivo: produção de conhecimento em saúde de adolescentes. Esc Anna Nery Rev Enferm 2009. Out/Dez; Vol. 13, n. 4 Disponível em: <http://www.scielo.br/pdf/ean/v13n4/v13n4a23.pdf>. Acesso em: 01 Set. 2019. p. 129-136.

LEFÈVRE, F.; LEFÈVRE A. M. C. Discurso do sujeito coletivo: um novo enfoque em pesquisa qualitativa (desdobramentos). 2. ed. Caxias do Sul: Educs, 2005. (Coleção Diálogos). 256p

MERCADO, L. P. L.; SILVA, A. M. da; GRACINDO, H.B.R. Utilização Didática de objetos digitais de aprendizagem na educação on- line. In: Educação à Distância: Abordagens Críticas. EccoS. Revista Científica, São Paulo, v. 10, n. 1, jan/jun. 2008. p. 105-123.

MORAIS, Elayne; RIBEIRO, Aline; AMIEL, Tel. Recursos Educacionais Abertos REA: um caderno para professores. Campinas, SP: Educação Aberta, 2011.<http://www.oecd.org/dataoecd/5/47/37351085.pdf >. Acesso em: 20 Jul. 2019.

MORIN, Edgar. A cabeça bem-feita: repensar a reforma, reformular o pensamento. Trad. JACOBINA, Eloá. 19 ed. Rio de Janeiro: Beltrand Brasil, 2011. $128 \mathrm{p}$.

OKADA, Alexandra. COLEARN 2.0 - coaprendizagem via comunidades abertas de pesquisa, práticas e recursos educacionais. Revista e-curriculum, São Paulo, v.7 n.1 Abril/2011. Disponível em: 
FORMAÇÃO DOCENTE: UM PROCESSO EM CONTÍNUA CONSTRUÇÃO DE CONHECIMENTOS ISBN: 978-85-5453030-3

<http://revistas.pucsp.br/index.php/curriculum/article/view/5813/4128>. Acesso em: 25 Agos. 2019. p.1-15.

PRETTO, N. L. Recursos Educacionais Abertos: práticas colaborativas políticas públicas. Salvador: Edufba; São Paulo: Casa da Cultura Digital. 2012.

ROMANÓ, R. S. Ambientes Virtuais para Aprendizagem Colaborativa no Ensino Fundamental. In: CONFERÊNCIA INTERNACIONAL DE TECNOLOGIAS DE INFORMAÇÃO E COMUNICAÇÃO NA EDUCAÇÃO, 3., 2003, Braga. Disponível

em:<http://www.nonio.uminho.pt/documentos/actas/actchal2003/05comunicaco es/Te

ma3/03RosanaRomano.pdf>. Acesso em: 01 jul. 2019.

TORRES, Patrícia Lupion. Laboratório on-line de aprendizagem: uma experiência de aprendizagem colaborativa por meio do ambiente virtual de aprendizagem: EUREK@KIDS. Cad. Cedes, Campinas, vol. 27, n. 73, p. 335352, set./dez. 2007

TORRES, Patrícia Lupion et al. Formação continuada on-line para professores Matice. Rev. Diálogo Educ., Curitiba, v. 8, n. 24, p. 433-444, maio/ago. 2008 


\title{
REFLETINDO SOBRE A MODALIDADE DE PESQUISA "ESTADO DA ARTE"
}

\author{
RODRIGUES, Rosilene Maria \\ UFTM \\ N30aty@hotmail.com \\ MARTINS, Eliana Bolorino Canteiro \\ UNESP \\ elianacanteiro@terra.com.br
}

\section{INTRODUÇÃO}

Propomo-nos inicialmente neste artigo trazer pontos do debate travado no âmbito científico acerca das divergências teórico-ideológicas entre as Ciências Humanas e Sociais e as demais. A trajetória histórica indica que pesquisadores da área social, se opuseram ao método positivista cartesiano e criaram novas metodologias e abordagens teóricas mais condizentes ao dinamismo da realidade social. Visão esta que é polêmica até hoje, quanto a sua validade metodológica e científica.

Mediante o debate sobre a validade metodológica das pesquisas em determinadas áreas científicas, destacamos em seguida o conhecimento construído no Serviço Social, visto que, este compõe a grande área das Ciências Sociais Aplicadas, e no Brasil possui um acervo teórico crítico construído historicamente por profissionais e pesquisadores, que the proporcionou o status de profissão que constrói conhecimento na área social, sendo inclusive reconhecida pelos órgãos de fomento de pesquisas e ainda consolidou sua base teórico-crítica para formação de profissionais e pesquisadores.

Por último abordamos a concepção e o percurso metodológico utilizado no "Estado da Arte". Destacamos que, embora essa modalidade de pesquisa possa ser utilizada em qualquer área de conhecimento, ela pode sustentar também um posicionamento ideológico, pois, com o objetivo de mapear e inventariar determinada produção de conhecimento, possibilita elucidar teorias e métodos utilizados a partir de concepções ideológicas.

Entendemos que o principal agente no processo de pesquisa é o pesquisador, é a partir do seu direcionamento ideológico que são lançados os contributos científicos postulados no âmbito das ciências. Por isso, enquanto pesquisadores da área social, ao utilizarmos essa modalidade de pesquisa, 
também somos alvo das mesmas contestações que giram em torno da verificabilidade e validade das pesquisas na área das Ciências Humanas e Sociais.

A relevância da modalidade de pesquisa "Estado da Arte" vai além do conteúdo de produções científicas, ela realiza um balanço do que já foi construído e permite um olhar mais acurado para a historicidade das produções científicas. Portanto, o texto pretende contribuir com os pesquisadores apresentando algumas peculiaridades e distinções dessa modalidade de pesquisa, que é muitas vezes confundida com procedimento metodológico.

Pontuamos aqui, que as reflexões desenvolvidas neste artigo surgiram durante o processo de mestrado em que as autoras estavam enquanto orientanda e orientadora, e buscávamos a compreensão da alternativa metodológica denominada - "Estado da Arte", considerando a riqueza do acervo científico construído e suas possibilidades para a ampliação de vários debates no Serviço Social. Trazemos considerações acerca do procedimento metodológico utilizado nesta modalidade de pesquisa - Estado da Arte, porém não é objetivo do presente artigo trazer resultados da referida pesquisa de mestrado, e sim contribuições para reflexão do tema em debates no âmbito da formação de pesquisadores.

\section{A PESQUISA EM CIÊNCIAS HUMANAS E SOCIAIS.}

Não pretendemos aqui aprofundarmos na dimensão conceitual dos componentes da pesquisa, seus vários métodos e os aportes teóricos em que ela se baseia, mas buscarmos a aproximação dos questionamentos que estão vinculados às divergências teóricas e ideológicas que se colocam entre Ciências Humanas e Sociais e as Ciências da Natureza.

Lembramos então que, de acordo com os fundamentos do desenvolvimento científico, as divergências surgiram na segunda metade do Século XIX, quando no campo da Filosofia, estudiosos buscaram interpretar a história humana como um todo e não somente como uma mera sucessão de acontecimentos.

As transformações em torno das pesquisas sociais, de acordo com Chizzotti (2014), podem ser expressas em cinco marcos que denotam a ampliação do seu campo e significado: a não aceitação da metodologia aplicada às Ciências da Natureza, no final do Século XIX e início do XX; a descoberta e utilização de pesquisas etnográficas na primeira metade do Século XX, buscando conhecer grupos sociais até então não estudados 
através de seus relatos e na sua linguagem cotidiana; a consolidação da pesquisa qualitativa, ocorrida entre o pós segunda Guerra e os anos de 1970, pois surgiram novas concepções e práticas (dentre elas as teorias críticas) criticando a hegemonia das pesquisas experimentais e a neutralidade do pesquisador tão postulada no discurso positivista, nesse marco também se iniciam os recursos advindos de programas e agências de financiamentos em prol das pesquisas sociais.

Outro marco importante ocorreu entre as décadas de 1970 e 1980, quando os investimentos em pesquisas sociais se ampliaram, oriundos de fundos públicos e privados. Temas como classe, gênero, raça e etnia trouxeram novos questionamentos das teorias, metodologias e processos analíticos, ampliando os debates e possibilitando novos referenciais em torno de questões como: a ética, o estatuto da verdade, o feminismo, o Terceiro Mundo e as multidões silentes. Nesse marco também se coloca a fusão entre as Ciências Humanas e Sociais.

O quinto e último marco, citado por Chizzotti (2014), traz a sociedade do conhecimento (ou da informação) no contexto da globalização a partir da década de 1990. O pesquisador está imerso na realidade em estudo. "Toda observação está possuída de uma teoria, o texto não escapa a uma posição no contexto político e a objetividade está delimitada pelo comprometimento do sujeito com a realidade circundante" (CHIZZOTTI, 2014, p. 56). São inseridos novos padrões de validade e legitimidade para a pesquisa social.

Mas, em conformidade com o mundo científico, a produção de conhecimento se realiza a partir da pesquisa, representada por um conjunto de métodos, que combinados com a base teórica e a criatividade do pesquisador, dão suporte ao processo investigativo e permite criar um novo trabalho a partir do existente.

A pesquisa é uma das maneiras que o ser humano encontrou para elaborar respostas a diversos problemas, é um "processo formal e sistemático de desenvolvimento do método científico. O objetivo fundamental da pesquisa é descobrir respostas para problemas mediante o emprego de procedimentos científicos" (GIL, 1999, p. 42). Em se tratando de dar respostas, ela pode "tanto preencher lacunas num determinado sistema explicativo vigente num momento histórico quanto colocar em xeque dado sistema" (MOROZ, GIANFALDONI, 2006, p.16).

Entre as críticas do meio científico no mundo ocidental está a de que a pesquisa científica se diz como forma hegemônica de dar respostas aos problemas da realidade, principalmente pela pretensão de ser única promotora 
de critérios de verdade e ignorar outros modos de pensar o mundo advindo, por exemplo, da religião e das artes.

A pesquisa exige que haja um caminho a ser seguido para alcançar o objetivo ou resposta ao questionamento. E nesse ponto possui um caráter social, uma vez que foi construída coletivamente a partir de ideias e representações do ser humano que foram sendo transmitidas e acumuladas ao longo da história, o que Ihe confere a característica de um processo, não linear, pois há situações em que esse conhecimento foi contestado e novas representações surgiram.

Embora não haja consenso entre os autores sobre as características que diferenciariam o conhecimento científico, em termos abrangentes consideramos que tal adjetivo deva ser aplicado ao conhecimento: que é fruto do questionamento a uma área de saber; que é fruto de procedimentos passíveis de reprodução por outra pessoa; que se expõe à interlocução da comunidade de pesquisadores da área de saber em questão. (MOROZ, GIANFALDONI, 2006, p. 16).

O conhecimento, portanto, é algo que pode ser percebido por vários ângulos, dependendo do pesquisador, de sua lente de visão e das técnicas utilizadas. No caso, a pesquisa em Ciências Sociais possui particularidades que no mundo científico permite que sua verificabilidade seja questionada. Autores como Gil (1999) e Minayo (2012) citam que essas questões dizem respeito às controvérsias no mundo científico sobre o caráter de cientificidade das Ciências Sociais em relação às Ciências Naturais. Isso porque as Ciências Naturais se dizem pioneiras da ideia de cientificidade, embora algumas de suas áreas sejam questionadas por entenderem que não alcançaram a expressão adequada, como é o caso da Física Quântica.

O campo científico, apesar de sua normatividade, é permeado por conflitos e contradições. E para nomear apenas uma das controvérsias que aqui nos interessa, citamos o grande embate sobre cientificidade das ciências sociais, em comparação com as ciências da natureza. Há aqueles que buscam a uniformidade dos procedimentos para compreender o natural e o social como condição para atribuir o estatuto de "ciência" ao campo social. Há os que reivindicam a total diferença e especificidade do campo humano (MINAYO. 2012, p.10).

As características das Ciências Sociais fornecem-lhe peculiaridades que as tornam imprevisíveis devido ao dinamismo da natureza humana, e também se constituem desprovidas de neutralidade, pois seu pesquisador compõe o universo pesquisado, imprimindo em seu objeto de pesquisa intencionalidades, sentimentos, emoções. As Ciências Sociais se propõem estudar a realidade social que é dinâmica, possui especificidades e diferenças que tornam a pesquisa imprevisível. 
As pesquisas sociais não fogem ao rigor científico, possuem metodologia, pressupostos epistemológicos e bases teóricas constituídas historicamente. O fato de não trabalharem somente com dados exatos e quantificados, não retira delas sua essência enquanto pesquisa e forma de aproximação do conhecimento.

O pesquisador busca a teoria de conhecimento, mais cabal,
que seja apta para explicitar a relação entre aquele que
conhece e as coisas que são conhecidas. Isto significa que a
pesquisa segue uma teoria articulada que contém princípios,
fundamentos lógicos e epistemológicos que sustentam a
análise da realidade e que tem alcance e valor esclarecedor
universal, em uma palavra, a epistemologia da pesquisa
(CHIZZOTTI, 2014, p. 26 , grifo do autor).

O pesquisador é o principal agente mediante a escolha dos caminhos da sua pesquisa, em relação à teoria e aos pressupostos que a validam enquanto forma de conhecimento.

Outros pontos podem ser ponderados em relação à pesquisa social, tais como: a expressividade multicultural dos povos, colocando em xeque a validade de práticas metodológicas; às questões ético-políticas, como a finalidade social das pesquisas (e aqui referimo-nos a todas e não somente as pesquisas sociais); a possibilidade de 'dar voz' aos silentes, como expressão contra-hegemônica; como instrumento utilizado para despertar a solidariedade e a dimensão humanitária, conscientes de sermos cidadãos planetários.

\section{PESQUISA NO SERVIÇO SOCIAL: sua relevância na construção do conhecimento na área.}

O Serviço Social compõe a área das Ciências Sociais Aplicadas e não escapa aos questionamentos acerca da epistemologia em que se realizam suas pesquisas. A trajetória histórica do Serviço Social brasileiro demonstra a relevância da pesquisa para a afirmação e consolidação da base teórica da profissão. Os avanços se deram a partir da produção de conhecimento que permitiu a sustentação teórica e metodológica para intervir na realidade de forma crítica e criativa. O conhecimento construído historicamente demonstra as transformações e os questionamentos vivenciados por seus sujeitos, para que o Serviço Social fosse reconhecido e respeitado como área de conhecimento. 
Nos primeiros anos da profissão, o que se destacou foi a forte influência da Igreja Católica, sendo que as expressões da "questão social", interpretadas como 'problemas sociais', eram vistas sob o prisma da moral. A ação profissional era reconhecida como um apostolado. O Serviço Social estava inserido no campo da prática e, devido a isso, "não precisava produzir conhecimento", mas agir. As determinações do contexto social da profissão, em sua fase inicial, condicionaram seus sujeitos em relação à produção de conhecimento, e nos primeiros anos há apenas indicações da presença da pesquisa no processo de formação dos profissionais.

Com a influência tecnicista norte-americana, após a década de 1940, o Serviço Social passou a trabalhar com a perspectiva funcionalista e a formação dos profissionais enfatizava o instrumental, tanto que as propostas de estudos estavam voltadas ao apoio à prática profissional (estudo de caso, grupo e comunidade), ou seja, ao 'trabalho de campo'. Os estudos tinham o objetivo de conhecer os males da sociedade e os recursos já existentes delimitarem o problema, e o que poderia ser feito para saná-lo. Eram estudos atrelados apenas à estatística, significava o contato inicial com o campo investigativo (pesquisa), caracterizado pela abordagem quantitativa.

Um fato importante nessa época foi a criação da Associação Brasileira do Ensino em Serviço Social (ABESS) em 19461, ampliando espaço para promoção de eventos e surgindo a ideia da apropriação de conhecimentos vindos de outras ciências que pudessem dar suporte ao trabalho de assistentes sociais no atendimento dos interesses do capital.

De acordo com Sposati (2007), o processo que permitiu ao Serviço Social dar um passo em direção à produção de conhecimento foi a articulação com outras áreas do conhecimento, como a Psicologia e a Sociologia, no trato com a técnica de diagnóstico social, em que os profissionais buscavam o reconhecimento da identidade dessa prática e como método de análise de relação indivíduo-meio. O diagnóstico social se assentava em princípios científicos relacionados à personalidade humana e à denominada física social.

Esses 'conhecimentos' demarcaram o fazer profissional até meados da década de 1960, quando a profissão teve contato com o movimento latino americano assentado numa base teórica social crítica e na Economia Política advindas do marxismo.

\footnotetext{
${ }^{1} \mathrm{Na}$ segunda metade da década de 1990, a ABESS passou a denominar-se ABEPSS Associação Brasileira de Ensino e Pesquisa, para contemplar a indissociabilidade do tripé ensino, pesquisa e extensão e articular graduação e pós-graduação em Serviço Social.
} 
De acordo com Setubal (2013), podemos considerar a existência de pesquisas na profissão nesse período que antecede a criação dos programas de pós-graduação. Elas possuíam duas tendências: uma que partia do Centro Brasileiro de Cooperação e Intercâmbio em Serviços Sociais (CBCISS). Essa tendência possuía características do pensamento conservador, marcadamente com perspectiva positivista. A outra partia do Centro Latinoamericano de Trabajo Social (CELATS) e possuía uma matriz marxista. Havia um ponto de convergência entre essas linhas, os questionamentos acerca da metodologia utilizada na intervenção.

A partir da década de 1960 para 1970, ocorre na America Latina e, especificamente no Brasil, um processo de renovação do Serviço Social, com uma forte crítica ao 'Serviço Social Tradicional2 que culminou na transformação das bases ideopolíticas que sedimentavam a profissão.

\begin{abstract}
Esse processo, cuja superação, foi de difícil trânsito, confrontou-se com a singularidade dos metodologismos onde predominava a micro escala de análise para ação no real e que levava, em sua logicidade, a superposição do método da pesquisa com método do diagnóstico social para ação profissional. Se na primeira é a produção de conhecimento que está posta como objeto/resultado, na segunda é a mudança da situação encontrada, a finalidade buscada, [...], em ambas existe uma direção social que orienta o sentido ético da ação profissional (SPOSATI, 2007, p. 16).
\end{abstract}

A partir desse período em que emergiram os questionamentos sobre as bases teórico-metodológicas que sedimentavam a profissão, as pesquisas no âmbito do Serviço Social ganharam um novo direcionamento ou finalidade, ou seja, mudar a realidade que está posta ao usuário e não mais analisar para conhecer, mas analisar para agir.

A implantação dos cursos de pós-graduação que teve início na Pontifícia Universidade Católica de São Paulo, na década de 1970, permitiu aos profissionais pós-graduandos o aprofundamento em metodologias científicas e sua difusão em outras instituições de formação profissional.

Além da expansão dos cursos de pós-graduação, outros fatores foram importantes para a difusão de técnicas de pesquisa e produção de conhecimento em Serviço Social, tais como: o surgimento da revista Serviço Social e Sociedade, em 1979; o apoio de agências de fomento à pesquisa

\footnotetext{
${ }^{2}$ Para aprofundamento do processo de renovação do Serviço Social verificar NETTO. J. P. Ditadura e Serviço Social: uma análise do Serviço Social no Brasil pós-64, 8ª ed. São Paulo: Cortez, 2008.
} 
como o Conselho Nacional de Desenvolvimento Científico e Tecnológico (CNPq) a partir da década de 1980, e a organização interna da categoria, que fez surgir, em 1982, um novo currículo para o curso de Serviço Social, integrando a pesquisa na formação profissional de Assistentes Sociais.

Para Sposati (2007, p. 17) "foi efetivamente a construção da nova cultura crítica no âmbito da profissão e da formação profissional que tem o mérito do fortalecimento da pesquisa para os assistentes sociais." A construção da cultura crítica que se deu nos anos de 1980 marcou o amadurecimento da profissão, instituiu-se o debate acadêmico e rompeu com o conservadorismo:
A década de oitenta consolidou, no plano ídeo-político, a ruptura com histórico conservadorismo do Serviço Social. Entendamo-nos: essa ruptura não significa que o conservadorismo (e, com ele, o reacionarismo) foi superado no interior da categoria profissional; significa, apenas, que - graças a esforços que vinham, pelo menos, de finais dos anos setenta, e no rebatimento do movimento da sociedade brasileira - posicionamentos ideológicos e políticos de natureza e/ou contestadora em face da ordem burguesa conquistaram legitimidade para se expressarem abertamente. É correto afirmar-se que, ao final dos anos oitenta, a categoria profissional refletia o largo espectro das tendências ídeo- políticas que tencionam e animam a vida social brasileira. Numa palavra, democratizou-se a relação no interior da categoria e legitimou-se o direito à diferença ídeo-política (NETTO, 1996, p. 111 apud BOURGUIGNON, 2008, p. 30-31).

Um dos avanços promovidos por esse processo de mudança no âmbito da profissão é a articulação nos debates das Ciências Sociais, em que o Serviço Social marca presença, nesse momento apresentando características de maturidade intelectual, rompendo com a concepção de campo limitado ao conhecimento prático.

[...] as décadas de 80 e 90 marcam historicamente avanços e conquistas para o Serviço Social nos seus diferentes campos de ação, bem como em seu processo de constituir-se e de consolidar-se como espaço de produção de conhecimento em seu próprio âmbito e frente às demais áreas de conhecimento (BOURGUIGNON, 2008, p. 32).

Os avanços no campo da crítica teórico-metodológica na pesquisa, de acordo com Bourguignon (2008), foram inúmeros, porém destacam-se: as reflexões que antes configuravam denúncias revelavam ações de enfrentamento dos seus dilemas; a ultrapassagem de "metodologismos" e aproximação de grandes matrizes do pensamento social contemporâneo; o 
ecletismo deu lugar à convivência plural de ideias no universo profissional. Esses pontos podem ser observados na produção científica a partir de 1980.

A pesquisa, a produção de conhecimento e as alternativas à instrumentalização na década de 1980 tiveram dois grandes eixos temáticos: a crítica teórico-metodológica ao conservadorismo e a busca pela historicidade da profissão visando à compreensão das particularidades do Serviço Social. Esses dois eixos temáticos articulados ao contexto histórico da sociedade brasileira daquele momento, período da redemocratização brasileira, da Constituição Federal de 1988 e da luta por direitos sociais, acrescentaram ao Serviço Social um "[...] conhecimento da dinâmica das transformações societárias que pressionam a profissão para reconstrução de alternativas teórico-metodológicas que sustentam a sua intervenção na realidade" (BOURGUIGNON, 2008, p. 34).

Se a década de 1980 marca o amadurecimento da profissão, a década de 1990 consolida a construção do projeto ético-político profissional3 através da massa crítica já produzida. É visível o reconhecimento da pluralidade teórico-metodológica, mas ocorre também o fortalecimento da orientação marxista na direção do projeto ético-político dos Assistentes Sociais.

De acordo com Bourguignon (2008), a agenda de pesquisas do Serviço Social na década de 1990 amplia os temas direcionados às políticas sociais na sua interface com o Estado, e que eram pautas na década de 1980, tais como: seguridade social após o marco da Constituição Federal de 1988; investigações sobre a sociedade civil; processos de gestão e controle das políticas públicas; papel dos conselhos de direitos; usuários do Serviço Social na sua relação com as políticas públicas são as mais pontuadas.

Os marcos mais recentes em pesquisa colocam em pauta as legislações sociais que regulamentam os artigos constitucionais e suas implementações tais como: a Lei Orgânica de Assistência Social, o Estatuto da Criança e do Adolescente, o Sistema Único de Assistência Social. Conforme cita Bourguignon (2008) a Assistência Social possui relevância na reflexão das pesquisas por ser campo privilegiado de atuação profissional e ter vinculação histórica com a natureza e constituição da profissão.

Para Bourguignon (2008) embora a agenda de pesquisas do Serviço tenha se ampliado, ela continua sendo uma exigência para o trabalho no mundo contemporâneo, e a profissão ainda carece de maiores

\footnotetext{
${ }^{3}$ Sobre o projeto ético-político, dois artigos são elucidativos: NETTO, J. P. A construção do Projeto ético-político do Serviço Social. In: Serviço Social e Saúde: Formação e Trabalho Profissional, 2006; e TEIXEIRA, J. B.; BRAZ, M. O Projeto Ético Político do Serviço Social. In: Serviço Social: Direitos Sociais e Competências Profissionais. Brasília, CEFESS/ABEPSS, 2009.
} 
investimentos e com um profissional permanentemente crítico e indignado com o modelo socioeconômico vigente que exclui socialmente vários segmentos populacionais.

Nesse sentido, Sposati lembra que a pesquisa em Serviço Social produz um conhecimento contra hegemônico e "[...] dedica-se a desvendar os invisíveis, os sem-voz, sem-teto, sem-cidadania." (2007, p. 18). Representa uma forma intensa de luta em favor da classe trabalhadora, explicita situações de opressão, preconceitos e injustiça social produzidas no contexto da sociabilidade capitalista vigente.

\section{ESTADO DA ARTE - ESTADO DO CONHECIMENTO}

Dentre as modalidades de pesquisa, destacamos o Estado da Arte ou Estado do Conhecimento, que é de caráter bibliográfico, e se constitui numa alternativa para inventariar e analisar os diversos momentos vivenciados pela pesquisa e produção do conhecimento em Serviço Social. Apresentamos um percurso metodológico a partir da mesma, visando a contribuir com referenciais para estudantes, pesquisadores e profissionais que pretendam utilizá-la.

As pesquisas com a denominação de "Estado da Arte" ou "Estado do Conhecimento" são de caráter bibliográfico, elas se diferenciam das pesquisas bibliográficas como procedimento metodológico porque possuem o objetivo de inventariar e analisar a produção científica, tais como: Teses, Dissertações, artigos publicados em revistas e trabalhos apresentados em anais de congressos, simpósios e outros eventos.

Definidas como de caráter bibliográfico, elas parecem trazer em comum o desafio de mapear e de discutir uma certa produção acadêmica em diferentes campos de conhecimento, tentando responder que aspectos e dimensões vêm sendo destacados e privilegiados em diferentes épocas e lugares, de que formas e em que condições têm sido produzidas certas dissertações de mestrado, teses de doutorado, publicações em periódicos e comunicações em anais de congressos e seminários. Também são reconhecidas por realizarem uma metodologia de caráter inventariante e descritivo da produção acadêmica e científica sobre o tema que se busca investigar, à luz de categorias e facetas que se caracterizam enquanto tais em cada trabalho e no conjunto deles, sob os quais 0 fenômeno passa a ser analisado (FERREIRA, 2002, p. 258).

O conceito de "estado da arte" é dado quando o estudo é abrangente e envolve vários tipos de produções sobre uma determinada área de conhecimento, conforme citado acima. Quando o estudo abrange somente 
um setor da produção ou uma modalidade de trabalho, denomina-se "estado do conhecimento".

Esse tipo de pesquisa se ampliou no Brasil no final do Século XX, após a década de 1980, apresentando temas variados e abordagens que vão além da análise dos objetos de pesquisa, incluiu também estudos sobre metodologias utilizadas nos trabalhos, produção por região, por período, por autores e orientadores.

De acordo com Romanowski e Ens (2006), pesquisadoras da área da Educação, os objetivos dessa modalidade de pesquisa advêm de inquietações e questionamentos de pesquisadores acerca da produção de conhecimento, buscando quantitativamente trabalhos sobre determinado tema e principalmente, a análise do conteúdo dos mesmos.

\begin{abstract}
O interesse por pesquisas que abordam "estado da arte" deriva da abrangência desses estudos para apontar caminhos que vem sendo tomados e aspectos que são abordados em detrimento de outros. A realização destes balanços possibilita contribuir com a organização e análise da definição de um campo, uma área, além de indicar possíveis contribuições da pesquisa para com as rupturas sociais (ROMANOWSKI, ENS, 2006, p. 38-39).
\end{abstract}

As referidas autoras acrescentam que essa modalidade de pesquisa é útil na identificação de aportes em relação à teoria-prática. Aponta restrições e dissemina lacunas de pesquisa, contribui com a divulgação de experiências inovadoras e proporciona o reconhecimento de propostas focalizadas, que não seriam observadas em detrimento de assuntos que possuem mais visibilidade, e também possibilita identificar temas relevantes, emergentes e recorrentes.

Quanto à metodologia, encontramos referências nessas mesmas autoras. Mas, buscamos referências no âmbito do Serviço Social, em autores que realizaram trabalhos com essa modalidade de pesquisa, ainda que não tenham se expressado conceitualmente como "Estado da Arte", seus estudos fizeram análises com base na produção de conhecimento na área de Serviço Social.

Para definição do percurso metodológico utilizamos referências em Romanowski e Ens (2006) - da Educação, e Lima e Mioto (2007) - do Serviço Social, pois encontramos congruências importantes que nos subsidiaram na observância do caminho a ser percorrido. Ambas informam que, primeiramente deve ser realizada a identificação e caracterização dos trabalhos de acordo com os objetivos da pesquisa, para posteriormente realizar uma análise do conteúdo, mesmo que seja apenas do resumo apresentado pelo trabalho acadêmico. 
A pesquisa do tipo "Estado da Arte" permite sua execução em fases que podem ser revisitadas ao longo da pesquisa, em razão do material em estudo não apresentar alterações, pois se tratam de trabalhos científicos. $O$ pesquisador tem autonomia para delinear seu percurso metodológico em concordância com os objetivos de sua pesquisa.

Dividimos o percurso metodológico dessa modalidade de pesquisa em duas fases: a primeira fase que compõe a elaboração do projeto e a identificação/seleção dos trabalhos a serem estudados. E a segunda fase sendo a análise dos trabalhos e obtenção dos resultados.

A elaboração do projeto em pesquisa do tipo "Estado da Arte" exige vigilância na formulação do problema em relação aos trabalhos científicos, pois de acordo com as autoras citadas, esse tipo de pesquisa tende a ser exploratório, descritivo e analítico, visando dar visibilidade ao conhecimento já produzido tanto por obra, como pelo conjunto; descrever o conteúdo e analisá-lo a partir de novas interpretações e identificar lacunas de estudos, temáticas recorrentes, divergentes e possibilidades não exploradas. $\mathrm{Na}$ fase de elaboração do projeto deve conter a escolha do tema e sua problematização e um plano que visa encontrar respostas aos questionamentos elaborados na problematização.

O envolvimento do pesquisador vai além de análises referentes ao objeto de estudo (tema em si), abrange análise de conceitos e posicionamentos ideológicos inseridos na produção que podem ser divergentes dos seus. Visto que não há neutralidade do pesquisador, é necessário explicitar a lente (método) que será utilizada para o encaminhamento da pesquisa, ou seja, em qual concepção teórica se baseia os objetivos propostos pela pesquisa.

A construção do roteiro da pesquisa sempre deve observar o que pedem os objetivos, "[...] o que requer do pesquisador muita clareza quanto a eles, sendo que ao empreender reformulações deve necessariamente rever os campos que compõem o roteiro" (LIMA E MIOTO, 2007, p. 43). A atenção quanto aos objetivos deve sempre constar em todas as fases da pesquisa para que o trabalho do pesquisador não vá além do proposto, tornando-se cansativo, com tendência a abordagem simplista, e nem fique aquém das possibilidades de análise, visto que o material empírico são trabalhos científicos.

Para Lima e Mioto (2007), a pesquisa bibliográfica permite ao pesquisador rever as possibilidades iniciais quanto ao objeto e ao roteiro de pesquisa, mesmo que já tenha construído um percurso ordenado de procedimentos: 
No entanto, não significa que os procedimentos a serem seguidos são determinados de uma vez para sempre, pois mesmo que o pesquisador tenha definido o objeto de estudo, o vínculo com determinada tradição e o desenho da investigação, ele sempre poderá voltar ao objeto de estudo à medida que forem obtidos os dados, de modo a defini-lo mais claramente, ou reformulá-lo. Consequentemente, esse movimento acarretará novas alterações, ou escolhas quanto aos procedimentos metodológicos. (LIMA e MIOTO, 2007, p. 40).

As autoras acrescentam que essa flexibilidade não está relacionada ao descompromisso com a sequência de procedimentos a serem cumpridos para a obtenção dos resultados, mas é a constante atenção aos objetivos e aos pressupostos da pesquisa enquanto processo científico.

Sem perder de vista os objetivos da pesquisa, a etapa de seleção dos trabalhos é realizada a partir do assunto (tema) a ser estudado, do período a ser observado, das modalidades de trabalhos e da localização ou base de dados a serem consultadas. Ou ainda, conforme cita Lima e Mioto (2007) por: parâmetro temático, linguístico (idiomas em que a obra está escrita), por fontes que se pretende consultar e por parâmetro cronológico de publicação. Esses critérios respondem às perguntas pré-elaboradas para o projeto de pesquisa: 0 quê? quando? onde? como?

Quanto aos critérios estabelecidos acima, Romanowski e Ens (2006) relatam que para pesquisas do tipo "Estado da Arte", recomenda-se que sejam feitas com publicações avaliadas por comitês científicos, como teses e dissertações que apresentam resultados de pesquisas e foram analisadas por bancas; também com base em periódicos referenciados nacionalmente e de trabalhos apresentados em congressos. Os outros critérios dependem dos objetivos traçados pela pesquisa.

É necessário, no momento de busca dos trabalhos, conforme recomendado por Romanowski e Ens (2006), a definição de "descritores" ou "palavras-chave" que direcionem as buscas em concordância com a(s) temática(s) a ser (em) estudada(s) e com os objetivos delineados na pesquisa.

Outro critério que pode ser utilizado, principalmente quando o pesquisador pretende trabalhar maior número de trabalhos, é a análise somente de títulos, resumos e palavras-chave, sem necessariamente consultar o conteúdo completo apresentado. Esse critério também possibilita a análise de trabalhos que apresentam somente resumos publicados.

Salientamos novamente que os critérios para essa busca dependem do que o pesquisador delineou previamente nos objetivos, mas que podem ser revistos no decorrer do processo à medida que encontrar elementos que possam dar mais consistência, coesão e clareza ao resultado. 
Essa etapa de seleção dos trabalhos pode reservar um dos maiores desafios referente a essa modalidade de pesquisa que é o acesso aos trabalhos, condição esta fundamental, e que se estende a outras etapas do processo de pesquisa. Isso porque as pesquisas do tipo "Estado da Arte" são realizadas através da disponibilidade dos bancos de dados das bibliotecas universitárias, em bases de dados de periódicos acessados pela plataforma de órgãos de fomento à pesquisa, em anais de eventos científicos e outros.

Se este material estiver disponibilizado somente por meio eletrônico, o pesquisador depende das possibilidades de acesso oferecidas pelo portal eletrônico dessas bases. Por exemplo, no caso da disponibilidade apenas de resumos dos trabalhos, os dados podem ser limitados quando os objetivos da pesquisa exigir conteúdo mais consistente.

Também há base de dados eletrônicos que possuem um grau de complexidade para acesso aos trabalhos, e que por o permitirem somente por palavras-chave, não dão conta de apresentar a totalidade dos trabalhos disponíveis, exigindo do pesquisador paciência e constantes buscas e retornos ao mesmo.

Os títulos dos trabalhos podem ser os primeiros indicativos para identificá-los quanto ao seu conteúdo, ainda que não constituam principal fonte de informação, merecem atenção, pois geralmente possuem o indicativo do assunto tratado. Porém "nem sempre o título da unidade dá uma ideia fiel ao tema. Às vezes apenas o insinua por associação ou analogia; outras vezes não tem nada que ver com o tema" (SEVERINO, 2007, p. 57), levando a identificação dos trabalhos para além do olhar sobre os títulos, pois eles podem estar escritos de forma subjetiva, devendo o pesquisador verificar também os resumos, as palavras-chaves, os sumários e outras informações contidas na obra para identificá-la como objeto de pesquisa.

No que concerne aos resumos e os outros subsídios textuais da obra, destacamos o que mencionaram Romanowski e Ens a respeito de algumas pesquisas da área da Educação: nessa etapa de identificação exige um processo de ida e volta constante ao resumo, buscando "estabelecer categorias de análise relativas ao tipo de formação, tipo de estudo, técnicas de pesquisas" (2006, p. 44), visando se certificar se determinado trabalho acadêmico compõe o universo de pesquisa.

Esse ponto apresenta desafios à identificação, visto que há resumos e palavras-chave que não são consistentes, omitem dados e se apresentam de forma sucinta, confusa ou incompleta4. Por isso, recomenda-se

\footnotetext{
${ }^{4}$ No entanto, Romanowski e Ens (2006) relatam que há pesquisas abrangentes na área da Educação que tiveram como objetivo analisar somente o conteúdo apresentado pelos resumos
} 
que, considerando os objetivos de análise do pesquisador, este vá além desses aportes, o que demonstra um grau de dificuldade tanto na identificação da obra, quanto no estabelecimento de critérios de busca do objeto de pesquisa.

Sobre a utilização dos resumos em pesquisas do tipo "Estado da Arte", Ferreira (2002) cita que eles devem ser lidos e analisados observando o contexto em que estão inseridos academicamente, porque compõem juntamente com os demais um corpus de apresentação e comunicação científica. São considerados gêneros do discurso acadêmico e buscam informar objetivamente o leitor a respeito do conteúdo, por isso, possuem uma relação de dependência com a íntegra do trabalho, com a apresentação de outras produções, e com seu autor. O resumo é "também enquanto realidade relativamente independente, produto de uma tensão construída na continuidade e na ruptura com o trabalho que lhe dá origem, numa relação dialética entre os gêneros [do discurso acadêmico], entre as condições de sua produção e práticas discursivas" (FERREIRA, 2002, p. 270).

Todas essas observações denotam a relevância dos resumos numa pesquisa do tipo Estado da Arte, pois, eles podem oferecer subsídios à identificação e caracterização do trabalho, posicionamentos ideológicos e metodológicos da comunidade acadêmica, mas também equívocos e imprecisões.

Pelo percurso metodológico que delineamos, a segunda fase será composta pela análise dos trabalhos e obtenção dos resultados, conforme já citado.

Para 0 momento de análise dos trabalhos, as autoras Romanowski e Ens o descrevem como "leitura analítica de resumos selecionados e tabulação dos dados, conforme categorização realizada" (2006, p. 44).

Lima e Mioto (2007) mencionam que a pesquisa bibliográfica é realizada a partir de leituras, e que nesse momento, inicialmente faz-se uma Leitura reflexiva ou crítica dos trabalhos (ou do material) selecionados, sendo este o "momento de compreensão das afirmações do autor e do porquê dessas afirmações [e posteriormente uma Leitura Interpretativa, sendo este] o momento mais complexo e tem por objetivo relacionar as ideias expressas na obra com o problema para o qual se busca resposta. [...] O critério norteador desse momento é o propósito do pesquisador." (LIMA E MIOTO, 2007, p. 41).

O nosso propósito quanto à análise dos trabalhos tem em vista 0 instrumental da análise de conteúdo, pois as buscas que objetivamos 
consideram os trabalhos de acordo com que pensam seus respectivos autores e o que estão mencionados no seu objeto de estudo.

Segundo Chizzotti (2014), há diversas formas de interpretação de textos e uma multiplicidade de técnicas, considerando sempre o critério norteador do pesquisador que envolve os objetivos da pesquisa. Mas, dentre as diversas formas se destaca a análise de conteúdo, pois ela "visa decompor as unidades léxicas ou temáticas de um texto, codificadas sobre algumas categorias, compostas por indicadores que permitam uma enumeração das unidades e, a partir disso, estabelecer inferências generalizadoras" (CHIZZOTTI, 2014, p. 113). É uma forma de observar a relevância e mesmo a frequência de determinadas ideias que aparecem em textos.

\begin{abstract}
São analisadas as palavras, as frases e temas que dão significado ao conjunto, para relacioná-las com os dados pessoais do autor, com a forma literária do texto, com o contexto sociocultural do produtor da mensagem: as intenções, as pressões, a conjuntura, a ideologia que condicionaram a produção da mensagem, em um esforço para articular o rigor objetivo, quantitativo, com a riqueza compreensiva, qualitativa (CHIZZOTTI, 2014, p. 116-117).
\end{abstract}

Franco (2008) acrescenta o fator 'subjetividade' dos autores que aparece nos diversos tipos de mensagens e que pode ser apropriada através da técnica da análise de conteúdo.

\begin{abstract}
Resumindo: o que está escrito, falado, mapeado, figurativamente desenhado, e/ou simbolicamente explicitado sempre será o ponto de partida para a identificação do conteúdo, seja ele explícito e/ou latente. A análise e a interpretação dos conteúdos são passos (ou processos) a serem seguidos. E, para o efetivo caminhar desse processo, a contextualização deve ser considerada como um dos principais requisitos, e mesmo como o pano de fundo para garantir a relevância dos sentidos atribuídos às mensagens (FRANCO, 2008, p. 16-17).
\end{abstract}

Nesse entendimento, a leitura para análise de cada trabalho deve relacioná-lo ao seu autor, à instituição e área científica pertencente, ao tempo histórico em que foi construído e ao contexto profissional em que ele ocorreu, quando for o caso.

Consideramos aqui que essa modalidade de pesquisa, quando inserida no âmbito das pesquisas sociais, segue os pressupostos filosóficos de seus autores, pois entendemos que não há neutralidade científica.

\title{
5. CONSIDERAÇÕES FINAIS, PORÉM INCONCLUSAS
}

A pesquisa é um dos pressupostos da formação e atuação profissional do Assistente Social, e é a partir dela que encontramos referências importantes para desenvolver outras reflexões. Constitui-se num instrumento 
de luta para além da academia, impactando no exercício profissional, através da práxis profissional, contribuindo assim, na sedimentação ou dinamismo das transformações teóricas e metodológicas. Ela integra uma dimensão densa na construção de conhecimento, oferece ao sujeito a possibilidade de criar, ser autônomo, construir.

Assim, de maneira breve e sucinta desacompanhada de outros questionamentos pertinentes à reflexão sobre o tema, trazemos indicativos que destacam a necessidade de aprofundar o conhecimento sobre o desafio das pesquisas de caráter bibliográfico, especificamente aquelas que se denominam "Estado da Arte", isto por não ser considerada tão relevante no contexto científico e sendo utilizada a partir de uma área do conhecimento pertencente às Ciências Sociais Aplicadas com intensa característica interventiva.

O Estado da Arte é uma modalidade de pesquisa que nos permite repensar o que já foi elaborado cientificamente. Não para efeito de reelaboração, (isso seria inviável), mas que seja consonante com a realidade que é dinâmica e abastecida de historicidade, para ampliar nossos "olhares" em torno do conhecimento. Traz a possibilidade de mapear e discutir certa produção acadêmica, nos mais diferentes campos do conhecimento, com intuito de tentar responder quais aspectos e dimensões têm sido privilegiados, onde, quando e como. Dessa forma é possível analisar historicamente a construção do conhecimento referente a uma determinada profissão e especificamente sobre uma temática que a envolve.

A compilação crítica de produções científicas partilha e difunde um conhecimento que pode ter permanecido isolado, tal como cita Guerra: "Sofremos ainda do isolamento das investigações, na medida em que o predomínio é da produção individual, fruto de monografias, teses e/ou dissertações." (2011, p. 147). No Estado da Arte reside a possibilidade da leitura articulada a várias outras leituras sobre um mesmo tema, recuperando a perspectiva da totalidade referente a produção do conhecimento naquele local e espaço temporal, sem perder a singularidade de cada pesquisa, pois essas expressam diferentes vertentes analíticas.

O debate sobre a produção do conhecimento nas pesquisas sociais, de forma específica no âmbito do Serviço Social, enfatizando a modalidade de pesquisa Estado da Arte, coaduna com a conjuntura histórica contemporânea, onde o Ensino Superior (incluindo a graduação e a pósgraduação) sofre os impactos do ideário neoliberal, que tem sido o receituário seguido, de forma particular, no Brasil. Assim, os programas de pós-graduação, onde ocorre parte significativa da produção do conhecimento, particularmente no Serviço Social, também resvalam os reflexos da mercantilização e precarização da política de educação. Podemos nos aproximar desses 
aspectos através da compilação e análise das produções científicas, atentando para os impactos e desafios que incidem sobre os programas de pósgraduação no Brasil e que foram apresentados através das produções.

Reportamo-nos a esse cenário, pois, a produção do conhecimento no Serviço Social tem se afirmado com expressividade, condição que pode ser confirmada pelo reconhecimento do esforço da Associação Brasileira de Pesquisa e Ensino em Serviço Social (ABEPSS) (em quase 70 anos de atividade) através da luta e empenho pela educação pública, laica, de qualidade e para todos, com ênfase no Ensino Superior.

A afirmação de Guerra (2011), em artigo comemorativo aos 65 anos da ABEPSS, realça a significativa contribuição da pós-graduação nesse processo de produção do conhecimento em Serviço Social:

[...] argumenta-se que a pós-graduação cumpriu um papel de monta na constituição da vertente crítica do Serviço Social brasileiro, que hoje detém hegemonia na produção do conhecimento e da pesquisa, responsável pela renovação da imagem profissional e por tornar o Serviço Social contemporâneo de seu tempo, colocando-o como interlocutor reconhecido no campo das ciências sociais. (GUERRA, 2011, p.126).

Portanto, através do mapeamento e análise do que já foi construído coletivamente em termos de conhecimento, reencontramos as expressões das históricas lutas da categoria profissional, reconhecemos as conquistas e os desafios que persistem no encalço do esforço dessa categoria para materializar o projeto ético-político do Serviço Social, fruto do acúmulo teórico-metodológico e ético-político dos profissionais conquistados através da produção científica fundamentado na vertente crítica.

Ressaltamos que nessa direção, os nossos estudos têm indicado que essa pesquisa bibliográfica - denominada: "Estado da Arte" - ao ser efetivada com rigor metodológico e postura crítica, se constitui numa significativa estratégia metodológica que possibilita contribuir com a produção do conhecimento em Serviço Social, ao revelar a multiplicidade de perspectivas, a pluralidade de enfoques, a evolução do conhecimento em relação a uma determinada temática de relevância para a profissão. Desta forma, é possível identificar o direcionamento que as pesquisas estão assumindo historicamente e identificar lacunas que ainda necessitam do investimento de outras pesquisas para aproximação investigativa mais incisiva em relação a um determinado assunto.

Abordamos vários aspectos acerca da modalidade de pesquisa Estado da Arte, ressaltando que as principais referências foram obtidas de pesquisadores de outras áreas do conhecimento, portanto com outros olhares, haja vista que essa modalidade de pesquisa não possui muitas referências no 
FORMAÇÃO DOCENTE: UM PROCESSO EM CONTÍNUA CONSTRUÇÃO DE CONHECIMENTOS ISBN: 978-85-5453030-3

Serviço Social. Portanto, ainda há muito a explorar em relação aos procedimentos metodológicos pertinentes ao Estado da Arte, principalmente sob o prisma do Serviço Social, por isso as considerações são inconclusas.

\section{REFERÊNCIAS}

BOURGUIGNON, J. A. A particularidade histórica da pesquisa no Serviço Social. São Paulo: Veras, 2008.

CARVALHO, D. B. B.; SILVA, M. O. S. (orgs.) Serviço Social, pós-graduação e produção de conhecimento. São Paulo: Cortez, 2005.

CHIZZOTTI, A. Pesquisas qualitativas em Ciências Humanas e Sociais. 6. ed. Petrópolis: Vozes, 2014.

FERREIRA, N. S. A. As pesquisas denominadas "Estado da Arte". In: Revista Educação \& Sociedade, ano XXIII, № 79, p. 257-272, Agosto 2002. Disponível em: <http://www.scielo.br/pdf/es/v23n79/10857.pdf>. Acesso em: 03 abr. 2014.

FRANCO, M. L. P. B. Análise de Conteúdo. Série Pesquisa, v. 6. 3. ed. Brasília: Liber Livro, 2008.

GIL, A. C. Métodos e Técnicas de Pesquisa Social. 5. ed. São Paulo: Atlas, 1999.

GUERRA, Y. A Pós-Graduação em Serviço Social no Brasil: um patrimônio a ser preservado. Temporalis, [S.I.], v. 2, n. 22, p. 125-158, fev. 2012. ISSN 2238-1856. Disponível em: $<$ http://periodicos.ufes.br/temporalis/article/view/2141/1607>. Acesso em: 12 Mar. 2015.

LIMA, T. S.; MIOTO, R. C. T. Procedimentos Metodológicos na Construção do Conhecimento Científico: a pesquisa bibliográfica. In: Revista Katálysis, v. 10, número especial, p. 37-45. Florianópolis, 2007. Disponível em: $<$ http://www.scielo.br/pdf/rk/v10nspe/a0410spe.pdf>. Acesso em: 03 abr. 2014.

MINAYO, M. C. S. (org.). Pesquisa Social: Teoria, método e criatividade. 32. ed. Petrópolis: Vozes, 2012.

MOROZ, M.; GIANFALDONI, M. H. T. A. O Processo de Pesquisa: iniciação. Brasília: Liber Livro, 2006.

NETTO, J. P. A construção do Projeto ético-político do Serviço Social. In: Serviço Social e Saúde: Formação e Trabalho Profissional, 2006. Disponível em $<$ http://www.fnepas.org.br/pdf/servico social saude/texto2-1.pdf> acesso em 11 maio. 2015 . 
FORMAÇÃO DOCENTE: UM PROCESSO EM CONTÍNUA CONSTRUÇÃO DE CONHECIMENTOS ISBN: 978-85-5453030-3

. Ditadura e Serviço Social: uma análise do Serviço Social no Brasil pós-64, 8. ed. São Paulo: Cortez, 2008.

ROMANOWSKI, J. P.; ENS, R. T. As Pesquisas denominadas do tipo "Estado da Arte" em Educação. In: Revista Diálogo Educacional, v. 6, no 19, p. 37-50. Curitiba, set./dez. 2006.2 Disponível em: $<$ http://educa.fcc.org.br/pdf/de/v06n19/v06n19a04.pdf >. Acesso em: 03 abr. 2014.

SETUBAL, A. A. Pesquisa em Serviço Social: utopia e realidade. 5. ed. São Paulo: Cortez, 2013.

SEVERINO, A. J. Metodologia do trabalho científico. 23. ed. rev. e atual. São Paulo: Cortez, 2007.

SPOSATI, A. Pesquisa e Produção de Conhecimento no campo do Serviço Social. In: Revista Katálisys, v. 10, número especial, p. 15-25. Florianópolis, 2007. Disponível em: <http://www.scielo.br/pdf/rk/v10nspe/a0210spe.pdf>. Acesso em: 09 Jul. 2013.

TEIXEIRA, J. B.; BRAZ, M. O Projeto Ético Político do Serviço Social. In: Serviço Social: Direitos Sociais e Competências Profissionais. Brasília, CEFESS/ABEPSS, 2009. 
REFLEXÕES QUE EMERGEM DO RESIDÊNCIA PEDAGÓGICA:

$A$ vivência dos licenciandos dos cursos de Letras e Matemática no projeto do Uni-FACEF

\author{
COSTA, Amanda Melo \\ Graduanda em Letras/Espanhol - Uni-FACEF \\ amanndsmelo@gmail.com \\ ANDRADE, Henrique Botelho de \\ Graduando em Letras/Inglês - Uni-FACEF \\ henriban@hotmail.com \\ ALVES, Maria Sílvia Rodrigues-Alves \\ Doutora em Linguística e Língua Portuguesa - Uni-FACEF \\ masilrodriguesalves@gmail.com
}

\title{
1. INTRODUÇÃO
}

O Programa de Residência Pedagógica faz parte da Política Nacional de Formação de Professores e é caracterizado pelo aprimoramento da formação de discentes dos cursos de licenciatura, incentivando, dessa forma, o licenciando em sua inserção na escola, a partir da segunda metade da graduação.

A participação no programa possibilita que o licenciando obtenha experiências a partir da vivência no âmbito escolar, assim como a relação com os alunos e professores. Uma das atividades abordadas pelo programa é a regência em sala de aula, que conta com a supervisão do professor preceptor e do coordenador institucional.

Uma vez que se trata de um projeto novo, no presente momento, algumas reflexões emergem a partir da vivência dos bolsistas no programa. Portanto, o objetivo desta pesquisa é refletir sobre o andamento do projeto e as consequências e vantagens que surgem do Programa de Residência Pedagógica na realidade do Uni-FACEF (Centro Universitário Municipal de Franca).

Para isso o referencial teórico-metodológico utilizado será uma revisão bibliográfica sobre o Edital do Programa de Residência Pedagógica (CAPES), além do Projeto Pedagógico do Uni-FACEF, sendo possível, dessa maneira, traçar um paralelo entre os dois documentos. Para contextualizar 0 cenário político, foram utilizadas notícias sobre a desenvoltura do projeto, 
desde a criação até sua implantação. Utilizamos, também, dos estudos de Gatti e Barretto (2009) sobre a trajetória da formação docente, Paulo Freire (1996) e de José Moran (2017) sobre educação e as relações docente e discente, para possibilitar uma demonstração da importância de programas como 0 apresentado na formação de profissionais da área de Licenciatura.

\section{A TRAJETÓRIA DA FORMAÇÃO DOCENTE BRASILEIRA}

O percurso dos cursos de formação de professores no Brasil é um assunto extenso e dividido em diferentes etapas. Neste artigo, serão apresentadas as principais etapas e as mudanças ocasionadas por elas no processo de formação docente.

O início do processo de formação de professores no Brasil ocorreu no final do século XIX, a partir das Escolas Normais, cujo objetivo era formar professores para o ensino das "primeiras letras", o nível secundário da época referida. Vale lembrar que a escolarização de tal época era escassa e não se destinava a toda a população. Mais tarde, no início do século $X X$, surgiu a necessidade de criação de cursos específicos para a formação docente, uma vez que, por conta da expansão industrial, tornou-se necessária uma maior escolarização da população. Com isso, nos anos de 1930 acrescentou-se mais um ano nos cursos de Bacharelado com disciplinas que contemplassem a área de Educação. A duração normal dos cursos era de três anos e, pelo acréscimo do ano da licenciatura, tais cursos receberam a denominação de cursos $3+1$. Gatti e Barretto (2009, p. 38) afirmam sobre o assunto que:

\footnotetext{
Desde as primeiras décadas do século XX havia se consolidado a formação de professores para o primário (anos iniciais de ensino formal) nas Escolas Normais de nível médio (secundário), e a formação dos professores para o curso secundário nas instituições de nível superior (licenciaturas).
}

Em 1971, ocorre a extinção das Escolas Normais, a partir da Lei no 5.692, a qual reformou a educação básica brasileira. Com isso, a formação proveniente das extintas Escolas Normais passou a acontecer no Magistério, uma Habilitação do ensino de segundo grau. Por esse motivo, algumas particularidades foram perdidas, dado o reajuste curricular que o ensino de segundo grau sofreu. Ao buscar mais qualidade na formação docente, o governo federal criou, em 1982, os Centros Específicos de Formação e Aperfeiçoamento do Magistério (Cefams), os quais se expandiram com o tempo e promoveram melhorias na formação oferecida. Ainda no ano de 1982, foi 
aprovada a Lei no 7.044/82, a qual alterava o artigo 30 da Lei $n^{0}$ 5.692/71, mantendo a Habilitação Magistério, porém apresentando outras opções de formação para docentes de anos iniciais e finais do Ensino Fundamental. Segundo Gatti e Barretto (2009, p. 40):

\begin{abstract}
Com essa lei instauram-se, então, os chamados cursos de licenciatura curta, em nível superior, com menos horas-aula do que as licenciaturas plenas, para formar docentes que poderiam atuar da $5^{\mathbf{a}}$ até a $8^{\underline{a}}$ séries, mas também de $1^{\underline{a}}$ a $4^{\underline{a}}$ séries. Esses cursos poderiam formar professores com integração de áreas, o que foi uma inovação; por exemplo, a licenciatura em Ciências (com componentes de Biologia, Física e Química), ou em estudos sociais (com componentes de História, Geografia, Sociologia).
\end{abstract}

A criação e implantação das licenciaturas curtas gerou controvérsias, o que levou o Conselho Federal de Educação (CFE) a emitir orientações normativas, alguns anos mais tarde, para que gradualmente esses cursos se tornassem cursos de licenciatura plena. Com isso, no final dos anos 1990 foi publicada a Lei de Diretrizes e Bases da Educação Nacional, a qual culminou com a promulgação das Diretrizes Curriculares Nacionais para a Formação de Professores no início dos anos 2000, as quais promoviam reformulações a serem instaladas nas Instituições de Ensino Superior.

\title{
2.1 O Estágio Supervisionado Obrigatório
}

Por abordarmos a vivência dos licenciandos dos cursos de Letras e Matemática do Centro Universitário Municipal de Franca (Uni-FACEF), nesta pesquisa tratamos do Regulamento Geral do Estágio Supervisionado e das regras vigentes para as turmas das respectivas licenciaturas no ano de 2019. $O$ presente Regulamento de Estágio contempla a DELIBERAÇÃO CEE N 111/2012, na qual constam, no Capítulo II (da formação de docentes para os anos finais do Ensino Fundamental e Ensino Médio), as seguintes informações:

Art. 11 O estágio supervisionado obrigatório, previsto no inciso III do art. 8ํㅡ, deverá ter projeto próprio e incluir:

I - 200 (duzentas) horas de estágio na escola, em sala de aula, compreendendo o acompanhamento do efetivo exercício da docência nos anos finais do ensino fundamental e no ensino médio, bem como vivenciando experiências de ensino, na presença e sob supervisão do professor responsável pela classe na qual o estágio está sendo cumprido e sob orientação do professor da Instituição de Ensino Superior;

II - 200 (duzentas) horas dedicadas ao acompanhamento das atividades da gestão da escola dos anos finais do ensino fundamental 
e do ensino médio, nelas incluídas, entre outras, as relativas ao trabalho pedagógico coletivo, conselhos da escola, reuniões de pais e mestres, reforço e recuperação escolar, sob orientação do professor da Instituição de Ensino Superior e supervisão do profissional da educação responsável pelo estágio na escola, e, em outras áreas específicas, se for o caso, de acordo com o projeto de curso de formação docente da instituição;

Portanto, de acordo com tal excerto da Deliberação já mencionada, o Estágio Supervisionado é um componente curricular obrigatório dos cursos de Licenciatura e, por esta razão, deve ser cumprido para a obtenção do certificado de conclusão de curso. Assim como consta na Deliberação, cada Instituição de Ensino Superior deve possuir seu próprio projeto para o Estágio Supervisionado. Por esta razão foram analisados os projetos de Estágio do curso de Letras e Matemática do Uni-FACEF.

O curso de Letras, neste centro universitário, é dividido entre três habilitações: Português, Português/Inglês e Português/Espanhol. Por essa razão, o estágio de cada habilitação funciona separadamente, sob a supervisão dos respectivos professores de Prática de Ensino das áreas. A divisão das horas para cada habilitação descreve-se da seguinte forma: 100 horas de observação, participação e regência em aulas de Língua Portuguesa; 100 horas de observação, participação e regência em aulas da disciplina da habilitação (Português, Inglês ou Espanhol); 100 horas de gestão de ensino e 100 horas de atividades teórico-práticas e de aprofundamento na área de ensino. As horas que compõem o estágio de Língua Portuguesa e horas de gestão começam a ser computadas a partir do $4^{\circ}$ semestre da graduação, que corresponde à segunda metade do curso. As horas correspondentes às habilitações são computadas a partir do $5^{\circ}$ semestre, uma vez que as aulas de Prática de Ensino de Língua Estrangeira são iniciadas neste semestre. Todas as 400 horas que compõem o Estágio Supervisionado devem ser finalizadas até $06^{\circ}$ semestre, ou seja, até o final da graduação5. No curso de Matemática do Uni-FACEF, os licenciandos também devem cumprir as 400 horas solicitadas na Deliberação, sendo que a divisão dessas horas é dada por 200 horas cumpridas no $4^{\circ}$ semestre da graduação e as outras 200 são divididas entre os dois últimos semestres do curso $\left(5^{\circ}\right.$ e $6^{\circ}$ semestre).

No Regulamento de Estágio de ambos os cursos consta que o Estágio Supervisionado deve ser cumprido em escolas da rede pública ou particular, de ensino regular, nos níveis Fundamental - anos finais $\left(6^{\circ}\right.$ ao $9^{\circ}$

\footnotetext{
${ }^{5}$ Tais considerações, acerca do número de horas a serem cumpridas no estágio supervisionado dos cursos de Letras e Matemática, se referem à grade dos cursos instaurada para o cumprimento da carga horária em três anos. Situação dos alunos graduandos, autores do presente artigo. A partir de 2019, o Uni-FACEF, fez adequações nas grades dos cursos de licenciatura, para atender à Deliberação CEE/SP no 111/2012, passando a 4 anos de curso. Desse modo, o estágio supervisionado se reconfigura na nova realidade
}

REFLEXÕES QUE EMERGEM DO RESIDÊNCIA PEDAGÓGICA: A vivência dos licenciandos dos cursos de Letras e Matemática no projeto do Uni-FACEF - pp. 114- 
anos) e Médio, sendo que, na maioria das vezes, esse estágio funciona de maneira não-remunerada, configurando, assim, uma obrigação a mais que o discente deve cumprir na graduação sem que haja um retorno monetário. Porém, a intenção principal do estágio é promover um "ensaio da docência" durante a formação, de modo que o licenciando possa ter contato direto com a futura profissão. Paulo Freire (1996, p. 12 - 13) afirma que:

\begin{abstract}
Ensinar inexiste sem aprender e vice-versa e foi aprendendo socialmente que, historicamente, mulheres e homens descobriram que era possível ensinar. [...] Aprender precedeu ensinar ou, em outras palavras, ensinar se diluía na experiência realmente fundante de aprender.
\end{abstract}

Diante dessa reflexão do autor, compreende-se que a docência é uma área que exige diversos estudos, pois, uma vez que só se pode ensinar a partir de quando se aprende, o estágio é o responsável por possibilitar esse aprendizado prático ao licenciando, fazendo com que teoria e prática sejam relacionadas. Há também a preocupação de que o ensino seja voltado para diversos modos de aprendizagem como afirma Moran (2017, p. 67):

\footnotetext{
Os processos de aprendizagem são múltiplos, contínuos, híbridos, formais e informais, organizados e abertos, intencionais e não intencionais. [...] A educação é mais complexa porque tem de preparar para a autonomia, para podermos tomar decisões mais complexas em todos os momentos, de forma criativa, empreendedora e realizadora. Para preparar para a autonomia, precisamos de outra proposta de escola, muito mais leve, aberta, flexível, centrada no aluno, com atividades significativas, metodologias ativas, intenso uso das tecnologias digitais.
}

Portanto, de acordo com o que afirma Moran, deve-se propor um modelo de escola que possa abordar os múltiplos processos de aprendizagem e, para isso, é necessário fugir do ensino tradicional e levar novos recursos para a sala de aula que possam auxiliar este processo. Sendo assim, programas que incentivam a busca por novas abordagens de ensino durante a formação docente são necessários, como é o caso do Residência Pedagógica.

\title{
3. O PROGRAMA RESIDÊNCIA PEDAGÓGICA
}

O Residência Pedagógica é um programa cujo objetivo é inserir o aluno da licenciatura nas escolas de educação básica, a partir da segunda metade do seu curso. Além disso, os participantes do programa recebem uma 
bolsa cujo valor depende da função dos membros6. As atividades do programa incluem regência de sala de aula, intervenção pedagógica, acompanhadas por um professor da escola com experiência na área de ensino do licenciando e orientada por um docente da sua Instituição Formadora, entre outras. Entre os objetivos do programa Residência Pedagógica, destacam-se:

i. Aperfeiçoar a formação dos discentes de cursos de licenciatura, por meio do desenvolvimento de projetos que fortaleçam o campo da prática e conduzam o licenciando a exercitar de forma ativa a relação entre teoria e prática profissional docente, utilizando coleta de dados e diagnóstico sobre o ensino e a aprendizagem escolar, entre outras didáticas e metodologias;

ii. Induzir a reformulação da formação prática nos cursos de licenciatura, tendo por base a experiência da residência pedagógica;

iii. Fortalecer, ampliar e consolidar a relação entre a IES e a escola, promovendo sinergia entre a entidade que forma e a que recebe $o$ egresso da licenciatura e estimulando 0 protagonismo das redes de ensino na formação de professores;

iv. Promover a adequação dos currículos e propostas pedagógicas dos cursos de formação inicial de professores da educação básica às orientações da Base Nacional Comum Curricular (BNCC).

O modo de funcionamento do programa se dá a partir das IES, as quais serão selecionadas por meio de um Edital público nacional para apresentarem projetos institucionais de residência pedagógica. Sendo assim, o Programa é desenvolvido juntamente com as Secretarias Estaduais e Municipais de Educação. Com isso, as Instituições de Ensino Superior participantes deverão organizar seus projetos Institucionais em conjunção com a proposta pedagógica das redes de ensino que receberão os seus licenciandos. Por fim, o regime de colaboração será efetivado por meio da formalização de Acordo de Cooperação Técnica (ACT) junto com o Governo Federal, por meio da Capes e o os estados, por intermédio das secretarias de educação de estado ou órgão equivalente. A participação do governo municipal se efetivará por meio de Termo de Adesão ao ACT, firmado por suas secretarias de educação.

Os participantes do Programa Residência Pedagógica são: os residentes (discentes com matrícula ativa em curso de licenciatura que tenham cursado o mínimo de $50 \%$ do curso ou que estejam cursando a partir do $5^{\circ}$

\footnotetext{
${ }^{6}$ Como dito, tais participantes recebem uma bolsa mensal com um determinado valor, sendo os residentes no valor de $\mathrm{R} \$ 400,00$, cumprindo, ao final do estágio, um total de 440 horas; o coordenador institucional no valor de $\mathrm{R} \$ 1500,00$; o docente orientador no valor de $\mathrm{R} \$ 1400,00$ e o preceptor no valor de $\mathrm{R} \$ 765,00$. Os valores formam parte do orçamento do programa no biênio 2018-2019.
} 
período); o coordenador institucional (docente da IES responsável pelo projeto institucional de Residência Pedagógica); o docente orientador (o docente que orientará o estágio dos residentes estabelecendo a relação entre teoria e prática) e o preceptor (o professor da escola de educação básica que acompanhará os residentes na escola-campo).

O programa foi, inicialmente, criado na intenção de modernizar o Programa Institucional de Bolsas de Iniciação à Docência (Pibid), que antes da reformulação contemplava discentes de todos os semestres da Licenciatura, porém após o novo Edital manteve o objetivo de iniciar os docentes nas escolas de educação básica, porém na primeira metade dos cursos de Licenciatura (Letras e Matemática).

Apesar de ser bem estruturado e trazer contribuições na formação do licenciando, também há críticas sobre o programa diante dos riscos que os futuros residentes podem ter de se tornarem mão-de-obra barata, contribuindo para restringir a contratação de novos professores. Para que isso não aconteça, é necessário um compromisso, de todos os atores, com a valorização do acompanhamento e a supervisão pedagógica do residente, dentro da dimensão formativa do processo.

\subsection{O cenário político 2018/2019 na implantação do Residência Pedagógica}

O Programa Residência Pedagógica foi lançado no dia 18 de outubro de 2017 no Âmbito da Política Nacional de Formação de Professores. Sendo o Programa uma modernização do Programa Institucional de Bolsas de Iniciação à Docência (Pibid), sua proposta é a melhoria na formação de professores com um acompanhamento maior e periódico.

Mendonça Filho, ministro da educação da época, explica que o princípio dessa modernização, é, principalmente, a união das redes de ensino e instituições formadoras:

O papel do professor é decisivo para transformar a realidade da educação no país. E para cumprir esse desafio temos discutido bastante [sobre] políticas públicas que valorizem o papel do professor. E a valorização a partir da formação inicial, com o espírito da prática da residência pedagógica, vai facilitar a amplitude do conhecimento prático do professor e melhorar seu conteúdo do ponto de vista de aprendizagem.

Em uma pesquisa do MEC, o Censo da Educação de 2016 mostra que muitos professores de Ensino Básico não possuem formação adequada e os programas da Capes chegam com a intenção de incentivar a formação de professores com o foco no contato com a prática da docência nas escolas. $O$ Pibid tem por objetivo iniciar as experiências dos licenciandos ainda na primeira 
metade do curso, com a intenção de fazê-los refletir sobre a prática profissional no dia a dia das escolas públicas, ao passo que o Programa Residência Pedagógica visa o aperfeiçoamento do Estágio Curricular Supervisionado, visto que é obrigatório para a formação acadêmica, com a imersão nas escolas na segunda metade do curso:

\begin{abstract}
Assim como no Pibid, cada selecionado será acompanhado por um professor da escola com experiência na mesma área de ensino do licenciando, e por um docente de instituição de educação superior. $\mathrm{O}$ lançamento desses dois editais, além de assegurar a continuidade do Pibid, visa o aperfeiçoamento da formação de professores para a educação básica e com a valorização dos cursos de licenciatura.
\end{abstract}

Sendo assim, com as reformas feitas nos programas de bolsas, a solução foi que formulassem não somente um programa de estágio, mas duas propostas, cujas abordagens que visassem ao aperfeiçoamento e assegurassem a permanência um do outro, valorizando a formação de professores.

Em 2018, ainda no governo de Michel Temer, os programas de bolsa sofreram grande risco devido aos cortes de gastos. Com isso, medidas deveriam ser tomadas, como, por exemplo, acabar com os programas. Para que isso não acontecesse, a Capes enviou um ofício pedindo que os projetos não fossem vetados. São expostas, no documento, as possíveis consequências dos grandes cortes de gastos para fins não obrigatórios, nos quais entra o Programa de Residência Pedagógica e demais programas de formação de professores:

\title{
2. Formação dos Profissionais da Educação Básica
}

Suspensão dos pagamentos de 105 mil bolsistas a partir de agosto de 2019, acarretando a interrupção do Programa Institucional de Bolsas de Iniciação à Docência (Pibid) (Edital $n^{\circ}$ 7/2018), do Programa de Residência Pedagógica (Edital $n^{\circ}$ 7/2018) e do Programa Nacional de Formação de Professores da Educação Básica (Parfor) (Edital no 19/2018).

Interrupção do funcionamento do Sistema Universidade Aberta do Brasil (UAB) e dos mestrados profissionais do Programa de Mestrado Profissional para Qualificação de Professores da Rede Pública de Educação Básica (ProEB), com a suspensão dos pagamentos a partir de agosto de 2019, afetando os mais de 245.000 beneficiados (alunos e bolsistas - professores, tutores, assistentes e coordenadores) que encontram-se inseridos em aproximadamente 110 IES, que ofertam em torno de 750 cursos (mestrados profissionais, licenciaturas, bacharelados e especializações), em mais de 600 cidades que abrigam polos de apoio presencial.

Além disso, o ofício traz outras possíveis consequências que não são apenas relacionadas à interrupção das bolsas, mas também a visão do exterior sobre o país: "Um corte orçamentário de tamanha magnitude 
certamente será uma grande perda para as relações diplomáticas brasileiras no campo da educação superior e poderá prejudicar a imagem do Brasil no exterior" (CAPES, 2018). Dessa forma, é certo que diversos fatores podem ser afetados com os cortes, mesmo que sejam para investimentos em áreas obrigatórias, como pagamento de servidores.

\section{O PROJETO RESIDÊNCIA PEDAGÓGICA NO UNI-FACEF}

O projeto de Residência Pedagógica do Centro Universitário Municipal de Franca - Uni-FACEF auxilia no aperfeiçoamento e imersão dos estudantes de licenciatura no Estágio Curricular Supervisionado dos cursos de Letras e Matemática, proporcionando a integração entre a IES e escolas de ensino básico. O projeto possibilita, aos residentes, a oportunidade de conhecerem integralmente o âmbito escolar e sua gestão, com o intuito de refletir sobre a importância da prática docente na formação dos licenciandos e também dos professores preceptores, propiciando uma formação continuada no meio teórico e nas experiências adquiridas a partir das aplicações de atividades práticas.

O projeto institucional é integrado por um subprojeto interdisciplinar que orienta as licenciaturas, o qual faz referência às linguagens verbais, matemáticas e digitais de acordo com a BNCC e, segundo esse documento, a Educação Básica deve:

[...] visar à formação e ao desenvolvimento humano global, o que implica compreender a complexidade e a não linearidade desse desenvolvimento, rompendo com visões reducionistas que privilegiam ou a dimensão intelectual (cognitiva) ou a dimensão afetiva. Significa, ainda, assumir uma visão plural, singular e integral da criança, do adolescente, do jovem e do adulto - considerando-os como sujeitos de aprendizagem - e promover uma educação voltada ao seu acolhimento, reconhecimento e desenvolvimento pleno, nas suas singularidades e diversidades. Além disso, a escola, como espaço de aprendizagem e de democracia inclusiva, deve se fortalecer na prática coercitiva de não discriminação, não preconceito e respeito às diferenças e diversidades (BNCC, 2017, p. 14)

A proposta do plano de ambientação dos residentes na escola e na sala de aula busca proporcionar, primeiramente, o reconhecimento do ambiente escolar em que estiverem inseridos, tal como o funcionamento e organização da escola e a montagem de um cronograma para participação do residente nas atividades administrativo-pedagógicas (reuniões, ATPC, 
planejamento, etc). A partir disso, os residentes começam a cumprir o estágio, com observações, participações e regências em sala de aula, sempre sob a supervisão dos professores preceptores, montagem de relatórios sobre as experiências adquiridas, discussões em reuniões semanais na IES das vivências entre residentes, preceptores e coordenadores.

A participação dos licenciandos nas atividades desenvolvidas no cotidiano escolar contribui para uma formação completa e efetiva no âmbito da gestão escolar e da visão da escola como um todo. Dessa forma, as discussões nas reuniões, juntamente com os preceptores e coordenadores, viabilizam as propostas de atividades e o repensar do processo de ensinoaprendizagem, entre outros direcionamentos para a capacitação de todos os envolvidos no ambiente escolar. O planejamento dos residentes nas reuniões do programa prepara-os para vivenciar situações do ambiente escolar e da sala de aula para que. desta forma. adquiram reflexões sobre a articulação entre teoria e prática e assim o estágio torna-se uma atividade participativa, contextualizada com a aplicação de atividades que correspondam às necessidades da unidade escolar.

\section{CONSIDERAÇÕES FINAIS}

Diante das informações apresentadas nesta pesquisa, algumas reflexões emergem do presente estudo. Ainda que o Estágio Curricular Supervisionado exija uma quantidade inferior (400 horas) e o Programa de Residência Pedagógica tenha a exigência superior de dedicação (440 horas), os residentes possuem a vantagem de receber a bolsa, auxílio mensal, o que valoriza a ação do licenciando nas atividades escolares, além de proporcionar um contato de qualidade com a escola e os respectivos professores e profissionais da educação.

As reuniões também apresentam a vantagem de orientar e direcionar o discente da Licenciatura nas atividades a serem desempenhadas no âmbito escolar, sejam elas práticas (observação, participação e regência de sala de aula) ou de gestão de ensino. Ademais, nessas reuniões, são propostas atividades a serem desenvolvidas tanto no momento de convívio, quanto em sala de aula. São discutidos e estudados, também, os planos de ensino a serem ministrados pelos residentes, oportunidade em que os preceptores e as coordenadoras do Programa podem opinar nas escolhas pedagógicas que o residente faz ao montar sua aula. 
Outro fator consequente da participação no Programa são os estudos sobre interdisciplinaridade, visto que o Residência une as licenciaturas de Letras e Matemática na prática docente, ponto importante destacado pela Base Nacional Comum Curricular, a qual diz que as disciplinas devem ser integradas para que haja uma maior agregação com o cotidiano e a vivência do estudante.

Conclui-se que o Programa de Residência Pedagógica, ainda que se trate de um programa novo em formação e andamento, é válido para a formação de novos profissionais da área da docência, uma vez que traz uma ressignificação do ensinar, relacionando teoria e prática, culminando no progresso e melhoria da educação brasileira, que se encontra em estado precário durante grande parte da história do país.

\section{REFERÊNCIAS}

CAPES. Ofício no 245/2018-GAB/PR/CAPES. 2018. Disponível em: https://sei.capes.gov.br/sei/controlador_externo.php?acao=documento_conferir \&codigo_verificador $=0746852 \&$ codigo_crc $=6755$ A444\&hash_download $=e f 5 e 65$ b749e9b6a0c124c56e438345f0dbb86d4b097fccd29f4b4221365642ee971b5a5 e507aea925d83d67d1d4d79f08696fa5be30b507aa19122ff68c396a9\&visualiza cao=1\&id_orgao_acesso_externo=0. Acesso em: 26/07/2019.

- Programa de Residência Pedagógica. 2018. Disponível em: http://capes.gov.br/educacao-basica/programa-residencia-pedagogica. Acesso em: 27/06/2019.

Iniciação à docência: CAPES publica editais do Pibid e do novo Programa de Residência Pedagógica. 2018. Disponível em: https://www.capes.gov.br/sala-de-imprensa/noticias/8778-capes-publica-editaisdo-pibid-e-do-novo-programa-de-residencia-pedagogica Acesso em: 09/07/2019.

CONSELHO ESTADUAL DE EDUCAÇÃO. Deliberação CEE No 111/2012. 2012. Disponível em: http://www.ccg.unicamp.br/files/cpfp/legislacao/DeliberaoCEE-111-2012---atualizada-pela-Deliberao-CEE-154-2017-.pdf. Acesso em: 14/07/2019.

FREIRE, Paulo. Pedagogia da autonomia: saberes necessários à prática educativa. São Paulo: Paz e Terra, 1996.

GATTI, Bernadete Angelina; BARRETO, Elba Siqueira de Sá. Professores do Brasil: impasses e desafios. Brasília: UNESCO, 2009. 
FORMAÇÃO DOCENTE: UM PROCESSO EM CONTÍNUA CONSTRUÇÃO DE CONHECIMENTOS ISBN: 978-85-5453030-3

MEC. Base Nacional Comum Curricular. 2017. Disponível em: http://portal.mec.gov.br/index.php?option=com_docman\&view=download\&alias =79611-anexo-texto-bncc-aprovado-em-15-12-17-

pdf\&category_slug=dezembro-2017-pdf\&ltemid=30192. Acesso em: 29/06/2019.

MORAN, José. Como transformar nossas escolas: novas formas de ensinar a alunos sempre conectados. In: CARVALHO, M. (Org.). Educação 3.0: Novas perspectivas para o Ensino. Porto Alegre: Sinepe/RS/Unisinos, 2017. p. 67.

MORENO, Ana Carolina. Quase 200 mil bolsistas da Capes podem ficar sem bolsa se orçamento de 2019 sofrer corte, diz conselho. 2018. Disponível em: https://g1.globo.com/educacao/noticia/2018/08/02/quase-200-mil-podem-ficarsem-bolsa-se-orcamento-de-2019-sofrer-corte-diz-conselho-da-capes.ghtml. Acesso em: 26/06/2019.

VERDÉLIO, Andreia. MEC vai oferecer 80 mil vagas de residência pedagógica em 2018.2017 .2 Disponível em: http://agenciabrasil.ebc.com.br/educacao/noticia/2017-10/mec-vai-oferecer-80mil-vagas-de-residencia-pedagogica-em-2018. Acesso em: 26/06/2019. 


\title{
UM OLHAR SOBRE AS CONTRIBUIÇÕES DO PROGRAMA RESIDÊNCIA PEDAGÓGICA PARA A FORMAÇÃO DE PROFESSORES
}

\author{
TORRES, Juliana de Oliveira \\ UNESP \\ MARTINO, Vânia de Fátima \\ Docente - UNESP
}

\section{INTRODUÇÃO}

Este artigo tem como objeto de discussão a formação inicial de professores, em específico o programa de iniciação à docência Residência Pedagógica/Edital Capes n. 06/2018, criado e implantado no ano de 2018 em todo o território nacional. Esse estudo tem enfoque na cidade de Franca - SP, no curso de licenciatura em História de uma universidade pública, e por consequência o estudo acerca das contribuições que esse programa pode trazer para os cursos de licenciatura no Brasil. O programa faz parte da política nacional de formação de professores, que há tempos tem apresentado propostas de ação direta na educação de docentes, tal como Programa Institucional de Bolsa de Iniciação à Docência (PIBID), Programa de Formação Inicial e Continuada, Presencial e a Distância, além do programa de Professores para a Educação Básica (PARFOR), entre outros. Nos últimos anos a formação de professores tem sido tema das políticas públicas em educação, dos programas e ações educacionais, dos currículos e principalmente das demandas das escolas, visto as avaliações em nível nacional, estadual e municipal da realidade e qualidade da educação.

Neste aspecto, a formação inicial apresenta-se como a sua própria denominação, um momento primeiro da constituição de um futuro profissional com elementos sólidos e reflexivos, fundamentais para atuar na escola básica. É neste contexto que a Residência Pedagógica se insere, propondo a partir da segunda metade do curso de graduação, como os estágios supervisionados, o contato com universo da escola básica, seus problemas, sua diversidade e necessidades, em constante transformação. $O$ projeto é realizado em consonância aos Estágios Supervisionados, através de ações vivenciadas na escola e prática docente, nos diferentes momentos presenciais, possibilitando a construção de experiências metodológicas de ensino inovadoras ou alternativas, intervenções distintas nos currículos, programas e projetos pedagógicos das escolas. Assim o projeto constitui-se como uma proposta sólida de introduzir e auxiliar os alunos da graduação no 
mundo docente, em uma linha similar de projetos inovadores, como a exemplo do PIBID/Capes, implantado em 2009.

No campo da formação dos professores de História, a realidade não é diferente. Os cursos de licenciatura em História são, em sua maioria, formados a partir de disciplinas de conteúdo específico, denominadas históricohistoriográficas e as de conteúdos "pedagógicos", onde se alocam os Estágios Supervisionados e a formação na prática. Tradicionalmente os Estágios Supervisionados constituem espaço isolado na formação de professores, não promovendo a integração e o diálogo dos conteúdos teóricos apreendidos na graduação e a construção de uma prática reflexiva que promova uma efetiva atuação na escola básica, tanto no decorrer da graduação, quanto posteriormente no exercício profissional.

Esta realidade está expressa nas condições de ensino de aprendizagem dos alunos e sua relação com a escola em que se insere. 0 cenário atual da educação pública é complexo e inegavelmente nosso olhar se volta ao professor e sua atuação e qualidade do seu trabalho, segundo Leonor Tanuri discute e argumenta, por exemplo, que o cenário atual da educação pública é complexo e inegavelmente o olhar se volta ao professor e sua atuação e qualidade do seu trabalho, esquecendo que a prática docente está diretamente relacionada à sua formação, em suas diferentes formas, "Apesar de todas as iniciativas registradas nas duas últimas décadas, o esforço ainda se configura bastante pequeno no sentido de investir de modo consistente e efetivo na qualidade de formação docente"(TANURI 200). O campo historiográfico da formação de professores se consolidou nas décadas de 80 e 90 com a ampliação das pesquisas nas universidades, dessa forma, podemos citar alguns pesquisadores que tratam esse tema de forma contundente apresentando as várias facetas do debate acerca da formação de professores.

A autora Bernadete Gatti em sua obra "Formação de Professores e Carreira" de 1997 estuda sobre o tema formação de professores no Brasil, ela aborda referências de muita relevância para o assunto, como a questão da influência na gestão escolar na profissão professor, o impacto das políticas públicas educacionais na formação de professores e trabalha de forma vasta a desvalorização e evasão de professores no Brasil, com dados significativos que comprovam esta realidade.

O pesquisador António Nóvoa em seu trabalho "Profissão Professor" de 1995 organizou textos que traçam um panorama da formação de professores. É apresentado uma perspectiva de análise plural, na medida em que o trabalho é composto por textos de grandes estudiosos na área de formação de professores, fazendo uma análise crítica sobre a formação dos docentes e perspectivas futuras para o professor. A obra coloca a formação de 
professores como debate não só para os estudiosos da área, mas sim para professores que se afastaram da universidade e da sua formação continuada afim de promover discussão sobre o assunto dentro do ambiente escolar.

Por fim, podemos citar o pesquisador Maurice Tardif em seu trabalho "Saberes Docentes e Formação Profissional" do ano de 2002 em que trata da formação de professores, o pesquisador dá enfoque na sua obra para o saber do professor na interface do individual e do social se desdobrando em âmbitos como diversidade e temporalidade. $O$ autor também aponta na sua obra a importância dos saberes cotidianos do professor e a reflexão para que sejam repensados de outra maneira as relações entre a teoria e a prática na formação de professores.

Partido dos estudos acima citados e outros neste campo de pesquisa, nossa proposta busca traçar um panorama sobre como esse assunto se deu na história e a importância do debate, além de elucidar a sua relevância ao logo do tempo. Entende-se que é necessária uma breve retrospectiva da formação de professores no Brasil, objetivando um entendimento mais amplo das políticas públicas e projetos voltados a melhoria da qualificação dos docentes para a escola básica ao longo do tempo.

Pensando a melhoria na qualificação e formação docente, alguns projetos vinculados as licenciaturas surgiram nas universidades nas últimas décadas, tendo como foco o aluno que ainda está na formação e o professor da escola pública que perdeu o contato com a universidade. Dentre eles destacamos os projetos como, PAFOR (Plano Nacional de Formação de Professores da Educação Básica) e o PIBID (Programa Institucional de Bolsa de Iniciação à Docência), e mais especificamente, nosso objeto de estudo, o Residência Pedagógica, em foco nesse projeto.

Cabe salientar que o PIBID foi o pioneiro dentro da perspectiva de formar alunos para a docência em contato direto e contínuo com a escola pública como uma iniciativa da Política Nacional de Formação de Profissionais do Magistério da educação básica, via Decreto Nº 6755/2009 em 29 de janeiro de 2009. Diante disso o projeto mais recente criado pela iniciativa da Política Nacional de Profissionais do Magistério da educação básica, foi o Residência Pedagógica. Criado no ano de 2017, o projeto abriu seu primeiro edital somente em 2018, cujo objetivo é auxiliar na licenciatura por meio da regência e intervenção pedagógica, enquanto os alunos ainda cursam a graduação para consolidar a fase de docência e principalmente a passagem de aluno para professor.

O programa Residência Pedagógica abrange todas as áreas da licenciatura que constam no currículo do Estado de São Paulo como Geografia, História, Matemática, Física, Biologia, Filosofia, Sociologia, Química e 
Português. Em nosso estudo analisamos especificamente o Residência Pedagógica de Franca aliado a licenciatura de história e especificamente ao Ensino de História. Dessa forma, faz- se necessário alguns resgates históricos que contextualizarão o objeto de estudo, ou seja, a formação de professores.

Preocupado com o problema da formação de professores o estado brasileiro, via decreto $01^{\circ}$ de março de 1823 , criou as escolas normais. Seguindo o modelo Lancasteriano7. A primeira escola normal foi fundada no ano de 1835 na cidade de Niterói - RJ e contava com cursos de formação de professores para o magistério e ensino secundário. É importante salientar que esses cursos não atendiam a demanda da época tanto em qualidade quanto em quantidade. Todavia, esse modelo acabou por ganhar força ao final do século XIX, principalmente no início do século XX, momento em que ocorreu a expansão das escolas primarias, a exemplo do Estado de São Paulo. No decorrer das décadas a escola de formação de professores para o magistério, conhecida por escola normalista, passou por diferentes reformas, a exemplo da liderada por Caetano de Campos, em que novos métodos passaram a ser utilizados. Uma das novas abordagens que a escola oferecia era a ênfase na prática, isso mostrou novas possibilidades tanto para os alunos quantos para os professores da época.

Com o advento do Estado Novo e a mudança da estrutura social do país, as tendências educacionais também absorveram novos olhares, dentre eles, da Escola Nova e da Associação Brasileira de Educação8 criada em 1924, ou seja, novas tendências educacionais já estavam em ascensão mesmo antes do início do Estado Novo. Um dos marcos da influência da Escola nova é o "Manifesto dos Pioneiros da Educação Nova" de 1932, via o movimento e o documento que tiveram influência direta na constituição de 1934. Um dos pontos que o Manifesto aponta, por exemplo, é o papel do educador:

"Certo, um educador pode bem ser um filósofo e deve ter a sua
filosofia de educação; mas, trabalhando cientificamente nesse
terreno, ele deve estar tão interessado na determinação dos fins de
educação, quanto também dos meios de realizá-los. O físico e o
químico não terão necessidade de saber o que está e se passa além
da janela do seu laboratório. Mas o educador, como o sociólogo, tem
necessidade de uma cultura múltipla e bem diversa; as alturas e as
profundidades da vida humana e da vida social não devem estender-
se além do seu raio visual; ele deve ter o conhecimento dos homens
e da sociedade em cada uma de suas fases, para perceber, além do

\footnotetext{
${ }^{7}$ O método também conhecido como método mútuo, onde o aluno mais adiantado ensinava os demais de forma coletiva, foi desenvolvido por Joseph Lancaster consistia em um grupo de alunos, no qual eles formavam uma classe ou círculo, onde cada um tinha um lugar pré-definido pelo seu intelecto. À medida que o aluno atingia certo nível de progresso, mudava seu posicionamento na classe ou círculo.

${ }^{8}$ Sua finalidade era promover a difusão e o aperfeiçoamento da educação e cooperar com as iniciativas que viessem ao encontro desse objetivo.
} 
aparente e do efêmero, "o jogo poderoso das grandes leis que dominam a evolução social", e a posição que tem a escola, e a função que representa na diversidade e pluralidade das forças sociais que cooperam na obra da civilização." (AZEVEDO, et al. 1932, p.1)

Com o Estado Novo em 1930, depois de várias reformas as escolas normais não representavam mais o modelo europeu inicial e sim as denominações necessárias ao estado brasileiro que agia de acordo com a necessidade de população. Nesse momento as Escolas Normais enfrentam reformas importantes, tais como fundamentais na consolidação de escolas de formação de professores. Nos próximos anos as escolas normalistas passaram a oferecer cursos com 5 anos que tinham como referências a Escola Nova, tanto pela concepção pedagógica, quanto ao uso de materiais de metodologia de ensino.

Acrescido a isso, temos o Estatuto das Universidades Brasileiras de 1931 como definitivo para que as Escolas Normais não fossem mais as únicas responsáveis pela formação de professores. Contudo, até meados de 1960 o maior número de professores ainda não era proveniente das universidades, visto que a expansão não foi satisfatória para atender a demanda da época. No ano de 1946 uma nova constituição entra em vigor indicando como ponto fundamental a necessidade de haver uma diretriz nacional para a educação, todavia a $1^{\circ}$ LDB (Lei $N^{\circ} 4024 / 61$ ) só foi promulgada em 1961.

A próxima fase importante do processo de formação de professores foi no período da ditadura militar no Brasil (1964-1985), manteve a LDB 4024/61, alterando algumas premissas significativas via decreto das leis № 5540/68 e №5692/71, que consistia respectivamente na reforma universitária e na reforma do ensino do $1^{\circ}$ e $2^{\circ}$ graus. A reforma universitária transformou as universidades em um ensino mais técnico, juntou departamentos, por exemplo, a História e a Geografia que se tornou a licenciatura dos Estudos Sociais e interviu significativamente na autonomia didática e administrativa das instituições. A reformulação do Ensino do $1^{\circ}$ e $2^{\circ}$ graus transformou o ensino em um modelo teórico, visando o mercado de trabalho, padrão estabelecido MEC/USAID e pelos consultores norte americanos no Brasil. Estas reformas acabaram por reduzir o ingresso no ensino superior e dar ênfase a criada licenciatura curta que implicava diretamente na formação de professores, principalmente nas instituições privadas de ensino. Outro ponto importante de mudança foi a obrigatoriedade de ingresso na escola a partir dos 8 anos de idade, além da padronização do currículo com um núcleo comum relativo as matérias de ensino. 
Traçado este retrospecto histórico de como se deu a formação de professores no Brasil, é importante colocar que após a redemocratização novos formatos se estabelecem, as políticas públicas e as pesquisas em educação passam a ser mais efetivas no campo da educação, destacamos a intenção de fomento à docência que ganha corpo nesse momento. Nesse cenário podemos destacar um programa como o Residência Pedagógica que vai ao encontro das propostas colocadas por muitos estudiosos da área, possibilitando uma contribuição tanto para a formação do discente quanto para a reformulação constante da profissão professor.

\section{Residência Pedagógica: O projeto e a Proposta;}

O edital do Projeto Residência Pedagógica foi aberto em agosto de 2018 pela CAPES, com a ideia de um aprimoramento do PIBID. Assim, com as alterações, o PIBID abarcaria os primeiros $50 \%$ da carga horária inicial do curso, enquanto o Residência Pedagógica os últimos $50 \%$ da carga horária total. Anteriormente o PIBID (programa de iniciação à docência) abarcava uma grande quantidade de alunos da licenciatura, independente da carga horária que esse aluno já teria cursado ou viria a cursar, a partir do $2^{\circ}$ ano da graduação, e se interessasse pela experiência prática na educação básica. É importante ressaltar que o PIBID não era um substitutivo e tão pouco válido como estágio, ou seja, mesmo o aluno participante do programa teria que cumprir normalmente as horas de estágio obrigatório. Como o PIBID não excluía o aluno das disciplinas pedagógicas de licenciatura, suas experiências no Projeto possibilitaram um compartilhamento com os alunos da graduação das atividades e formação junto ao projeto.

Atendendo ao chamado do Edital a Faculdade de Ciências Humanas e Sociais - Unesp de Franca - licenciatura em História, participou do projeto "O Uso de Diferentes Fontes e Linguagens para o Ensino de História em sala de aula" tendo sido comtemplado com 24 bolsas de alunos licenciados, 3 preceptores (professores de escolas parceiras bolsistas), 2 coordenadores/professores da universidade (1 bolsista e o outro voluntário) e três escolas parceiras de ensino fundamental e médio.

Assim, o Projeto Residência Pedagógica, que está em vigor há mais de 12 meses, tendo como objetivo geral a formação dos alunos, em contato com a realidade educacional no decorrer da graduação. Neste sentido, possibilita aos graduandos da licenciatura em História a construção e aplicação de metodologias diferenciadas de ensino de história voltadas a alunos do ensino fundamental II e ensino médio da escola pública. A ideia é desenvolver um conhecimento aliado as teorias e práticas do ensino de história, tendo como foco as fontes e linguagens históricas que permitem o conhecimento histórico como, por exemplo, a música, o cinema, a literatura, a fotografia, entre outros 
tipos de linguagens, levando em conta o currículo do Estado de São Paulo para as séries envolvidas no projeto. Essa prática deve ligar-se diretamente com a realidade que o estudante está inserido, o discente para tanto deve construir um vínculo com o aluno e com a escola de forma a facilitar o processo de aprendizagem de ambos.

Outro objetivo da Residência é a articulação com o projeto político pedagógico do curso de História da UNESP de Franca, aperfeiçoando a formação dos discentes de licenciatura, por meio de desenvolvimento de projetos que fortaleçam a prática e aprimorem as atividades de estágio supervisionado, como citado abaixo:

"Em consonância o Projeto Político Pedagógico da Licenciatura em
História da UNESP de Franca, explicita com relação à Prática de
Ensino e o Estagio Supervisionado que "A prática, como componente
curricular, é sempre realizada em estreita "articulação com a escola
básica e com os projetos pedagógicos de seus cursos", estando
acoplada aos aspectos teóricos de cada curso e voltada para a
integração do conhecimento dos conteúdos específicos com os
mecanismos próprios de transmissão dos mesmos"." (Franca, Projeto
Residência Pedagógica, 2018, p.1)

Além disso, a Residência Pedagógica foi organizada em consonância ao Estágio Supervisionado, como componente curricular do curso de História/Unesp Franca, que estabelece desde o $5^{\circ}$ semestre $\left(2^{\circ}\right.$ metade do curso) atividades de contato com o ambiente escolar, o estudo do projeto político pedagógico das escolas, a observação, participação e regência em aulas de História, contato com reuniões de ATPC e com a gestão escolar, entre outras coisas, com foco para interação dos campos de ensino de história, suas diferentes proposições historiográficas e didático pedagógicas, planejamento de todo o aparato didático, no intuito de criar múltiplas possibilidades, cuja formação ampla e crítica do futuro professor é o objetivo principal.

Após a apresentação do projeto e a compreensão da proposta que ele sugere, a próxima etapa foi a seleção dos alunos que participam dele baseada em critérios estabelecidos pelos docentes. Infelizmente o Residência Pedagógica conta com 24 bolsas o que não engloba todos os estudantes matriculados no curso de História/Unesp Franca, o que acaba por não abarcar todos os interessados. A seleção desses alunos foi feita por meio de entrevistas e revisão do histórico escolar sujo, tendo em vista que se trata de um projeto com bolsa de agência conceituada como a CAPES.

Tendo os 24 bolsistas selecionados foi apresentado o projeto a todos os envolvidos, inclusive os preceptores selecionados juntamente com a escola indicada pela Diretoria de Ensino Regional de Franca. Os preceptores são os professores de escola pública que orientam os residentes dentro das escolas e ministram as aulas e atividades junto deles. Os docentes da 
universidade ficam responsáveis pelas orientações, indicações de leitura, supervisionar as atividades junto aos estágios, as oficinas e a construção de relatórios e trabalhos científicos, entre outras coisas que agregam na formação de professores e não são abarcadas nas disciplinas pedagógicas, visto a amplitude de temas. O projeto prevê uma carga-horária semelhante ao Estágio Supervisionado (I a IV), ou seja, 440 horas a serem cumpridas em 18 meses, em especial com 100 horas de regência, visto o total efetivo destas atividades.

Um dos primeiros passos no Residência pedagógica foi levar o aluno da licenciatura a ter familiaridade com a escola na qual ele iria trabalhar no decorrer dos 18 meses, assim os 6 primeiros meses do projeto destinado ao conhecimento do ambiente escolar e regras de como funciona a instituição em questão. Para as atividades concomitantes de Estágio Supervisionado este é o momento em que o aluno toma contato com a dinâmica da gestão escolar, e todo o funcionamento estrutural da escola, que é relevante e dá suporte ao processo formativo dos alunos da escola básica. Esta fase do projeto foi vistoriada e orientada pelos preceptores da escola garantindo que todos os bolsistas tivessem uma experiência extremamente frutífera.

Além disso, o programa pressupôs reuniões de estudo semanais (total de 100 horas), para edificar o conhecimento acerca das teorias da educação e metodologias do ensino da História. As reuniões, consistem em espaço de leitura, mas também em campo de discussão e troca de experiências, temas que permeiam a formação de professores e das práticas pedagógicas, em distintas realidades. Os autores selecionados tratam de campos abrangentes e interdisciplinares da educação, com ênfase na prática educativa.

Dentre os autores estudados estão Antônio Nóvoa, Bernadete Gatti, Isabel Alarcão, Maurice Tardif., Hannah Arendt, Vigotski e do campo do ensino da História, Circe Bittencourt, Jörn Rüssen, Maria Auxiliadora Schmidt entre outros. Todos estes pesquisadores ofereceram um acervo que tornou possível que todo aluno de licenciatura tivesse, até o momento um conjunto de conhecimento a respeito da formação docente, do ensino da História e das diferentes ações em sala de aula, além de atender ao proposto pelo projeto, ou seja, uma junção entre o conhecimento prático e o conhecimento teórico.

Embora o programa Residência Pedagógica tenha seu foco no campo da licenciatura, um dos objetivos do projeto de História da UNESP de Franca foi a promoção da pesquisa em educação, levando ao graduando um conhecimento a respeito do saber acadêmico, tanto no aspecto técnico como analítico, promovendo um conhecimento edificado e sólido acerca do tema. O projeto faz uma mediação dessa relação por meio de leitura de artigos da 
área de educação e a produção de conteúdo como resumos, resenhas, artigos e por fim um possível projeto de pesquisa sobre determinado assunto escolhido pelo licenciando, com vistas a formação futura.

Parte-se do pressuposto que a formação do licenciado deve ser ampla e consistente com vistas a sua futura atuação no campo da educação, como afirma Bernadete Gatti:

\begin{abstract}
"Esse desenvolvimento profissional parece, nos tempos atuais, configurar-se com condições que vão além das competências operativas e técnicas, aspecto muito enfatizado nos últimos anos, para configurar-se como uma integração de modo de agir e pensar, implicando num saber que inclui a mobilização de conhecimentos e métodos de trabalho, como também a mobilização de intenções, valores individuais e grupais, da cultura da escola; inclui confrontar ideias, crenças, práticas, rotinas, objetivos e papéis, no contexto do agir cotidiano, com seus alunos, colegas, gestores, na busca de melhor formar crianças e jovens e a si mesmos." (GATTI, 2016, p.169)
\end{abstract}

Tendo em vista essa necessidade de agir diretamente como um agente formador é que atua o residente em uma realidade na qual ele é responsável por aprender e construir ferramentas adequadas ao mundo contemporâneo e a realidade do aluno da escola atual. E a História enquanto disciplina formadora de identidade e cidadania, torna-se um dos principais veículos desta formação integral e significativa. É nesse panorama que esse trabalho busca saber as contribuições que esse programa pode trazer para os professores formados em história e a identificação com a profissão professor que apresenta múltiplas facetas.

\title{
6. CONSIDERAÇÕES FINAIS
}

É notável as deficiências envoltas no campo de formação de professores, dessa forma, o debate sobre esse tema é essencial na sociedade atual. Nesse cenário torna-se relevante estudar experiências, casos, estudos acadêmicos, entre outras ferramentas que contribuíram e contribuem para esse campo, para lidar da melhor forma possível com as questões que surgem no caminho, como um baixo rendimento do campo docente, desatualização de professores, falta de motivação com a profissão, reflexo nos alunos, entre outras coisas, e atingir todas as facetas e conflitos aparentes com as políticas públicas.

Esse trabalho se traduz no estudo de uma política pública concreta que abre possibilidades para uma melhoria do professorado adjunto a disciplina de história, que se mostra fundamental para cumprir a função social da educação enquanto disciplina formadora de identidade e cidadania. 
Segundo Bernadette Gatti é necessária uma verdadeira revolução nas estruturas institucionais formativas e nos currículos de formação (Gatti 2010). Portanto a formação de Professores deve estar em constante mudanças, de forma que, lida com diversas gerações e suas características sociais, sendo assim maior a possibilidade de atingir a sociedade e exercer a função social da educação.

\section{CORPUS DOCUMENTAL}

BRASIL. O Manifesto dos Pioneiros da Educação Nova. Brasília. 1932. Disponível em: http://www.histedbr.fe.unicamp.br/revista/edicoes/22e/doc1_22e.pdf>. Acesso em: 24 de junho de 2019.

. Decreto de 10 de março de 1823. Cria ema Escola de primeiras letras, pelo método do Ensino Mútuo para instrução das corporações militares. Coleção das Decisões do Governo do Império do Brasil de 1823. Rio de Janeiro: Imprensa Nacional, 1887.

. Lei $n^{\circ} 4.024$, de 20 de dezembro de 1961. Fixa as diretrizes e bases da educação. Disponível em: https://www2.camara.leg.br/legin/fed/lei/1960-1969/lei-4024-20-dezembro1961-353722-publicacaooriginal-1-pl.html>. Acesso em: 24 de junho de 2019

. Lei $n^{\circ} 5540$, de 20 de novembro de 1968. Fixa normas de organização e funcionamento do ensino superior e sua articulação com escola média, e dá outras providências. Disponível em: https://www2.camara.leg.br/legin/fed/lei/1960-1969/lei-5540-28-novembro1968-359201-publicacaooriginal-1-pl.html>. Acesso em: 24 de junho 2019

Lei $n^{\circ}$ 5.692, de 11 de agosto de 1971. Fixa as diretrizes para o ensino de $1^{\circ}$ e $2^{\circ}$ graus, e dá outras providências. Disponível em: https://www2.camara.leg.br/legin/fed/lei/1970-1979/lei-5692-11-agosto-1971357752-publicacaooriginal-1-pl.html>. Acesso em: 24 de junho de 2019.

Decreto $n^{\circ}$ 6.755, de 29 de janeiro de 2009. Institui a Política Nacional de Profissionais de Magistério de Educação Básica, disciplina a atuação da CAPES no fomento a programas de formação inicial e continuada, e outras providências. Disponível em: http://www.planalto.gov.br/ccivil_03/_ato2007-2010/2009/decreto/d6755.htm>. Acesso em: 24 de junho de 2019.

Lei $n^{\circ} 13.473$, de 08 de agosto de 2017. Institui a seleção de Ensino Superior interessadas em implementar Projetos Institucionais de Residência Pedagógica. Disponível em: https://www.capes.gov.br/images/stories/download/editais/01032018-Edital-62018-Residencia-pedagogica.pdf>. Acesso em: 24 de junho de 2019. 


\section{REFERÊNCIAS}

BERTOTTI, Rudimar Gomes; RIETOW, Gisele. Uma Breve História da Formação Docente no Brasil: Da Criação das Escolas Normais as Transformações da Ditadura Civil-Militar. In: Congresso Nacional de Educação, 11., 2013, Curitiba. Anais [...]. Curitiba: Pontifícia Universidade Católica do Paraná, 2013. p. $13795 \quad-\quad 13805 . \quad$ Disponível em: https://educere.bruc.com.br/CD2013/pdf/8746_5986.pdf>. Acesso em 24 de junho de 2019.

CARVALHO, Rita Cássia Gonçalves de. As Transformações do Ensino no Brasil: Análise das Reformas. HISTEDBR, Campinas, p. 1-27, 2006. Disponível em: http://www.histedbr.fe.unicamp.br/navegando/periodo.html>. Acesso em: 24 de junho de 2019.

CASTANHA, André Paulo. A Introdução do Método Lancaster no Brasil: História e Historiografia. In: Seminário de Pesquisa da Região Sul, 9., 2012, Caxias do Sul. Anais [...]. Caxias do Sul: ANPED, 2012. p. 1-16. Disponível em:

http://www.ucs.br/etc/conferencias/index.php/anpedsul/9anpedsul/paper/viewFil e/1257/12>.Acesso em: 24 de junho de 2019

FONSECA, Genaro Alvarenga; MARTINO, Vânia Fátima de. O Programa Residência Pedagógica: $O$ Uso de Diferentes Fontes e Linguagens para 0 Ensino de História em sala de aula. Franca. 2018. (separata) ${ }^{9}$

GATTI, Bernadette Angelina. Formação de Professores e Carreira: Problemas e Movimentos de Renovação. Campinas: Autores Associados, 1997.

Formação de Professores: Condições e

Problemas Atuais. Revista Internacional de Formação de Professor. v. 1, n.2, 2016. Disponível em: https://periodicos.itp.ifsp.edu.br/>. Acesso em 24 de junho de 2019

HENICK, Angelica Cristina; FARIA, Paula Maria Ferreira. História da Infância no Brasil. In: Congresso Nacional de Educação, 12., 2015, Curitiba. Anais [...]. Curitiba: Pontifícia Universidade Católica do Paraná, 2015. p. 25825 - 25834. Disponível em: https://educere.bruc.com.br/arquivo/pdf2015/19131_8679.pdf>.Acesso 24 de junho de 2019.

MARTINO, Vânia Fátima de; DAVID, Alessandra (organizadoras). Ensino de História I: Estudos e Experiências. Curitiba: CRV, 2018. (Coleção Ensino de História, v. 1)

NÓVOA, António. Profissão Professor. Tradutores: Irene Lima Mendes, Regina Correia, Luísa Santos Gil. 2.ed. Porto: Porto Editora, 1995.

\footnotetext{
${ }^{9}$ Este documento é um documento restrito aos participantes do RP, cedido para a construção do projeto e para pesquisa futura.
} 
SAVIANI, Dermeval. Escola e Democracia. 31.ed. Campinas: Autores Associados, 1997. (Coleção polêmicas do nosso tempo; v.5)

Pedagogia Histórico - Crítica: Primeiras Aproximações.

5.ed. Campinas: Autores Associados, 1995. (Coleção polêmicas do nosso tempo; v. 40)

TARDIF, Maurice. Saberes Docentes e Formação Profissional. 12.ed. Petrópolis: Vozes, 2011.

VIGOTSKY, Lev Semenovitch. Pensamento e Linguagem. Tradução: Jefferson Luiz Camargo. 4.ed. São Paulo: Martins Fontes, 2008. 


\section{ÍNDICE}

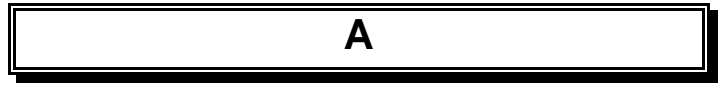

ALVES, Maria Sílvia Rodrigues-

Alves, 114

ALVES, Mauricio Conrado, 18

ANDRADE, Henrique Botelho de,

114

AZEVEDO, Gabriela Herculano, 9

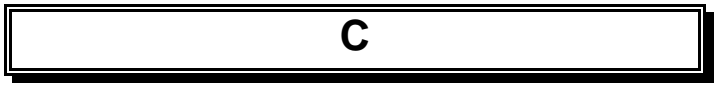

COELHO, Lucinda Maria de Fátima

Rodrigues, 18

COSTA, Amanda Melo, 114

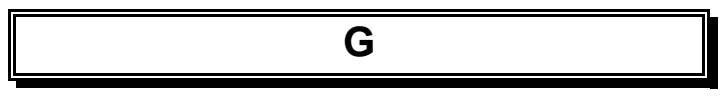

GUERRA, José Alfredo de Pádua, 46

GUERRA, Sandra Aparecida

Ferreira, 46

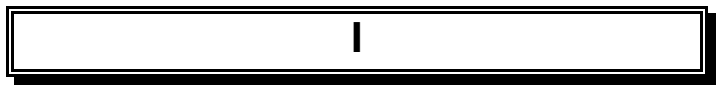

IVAN, Maria Eloísa de Souza, 9

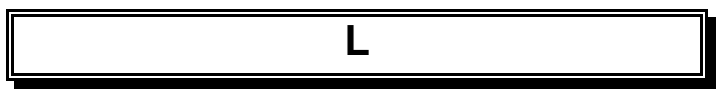

LUCAS, Cecy de Sousa, 64

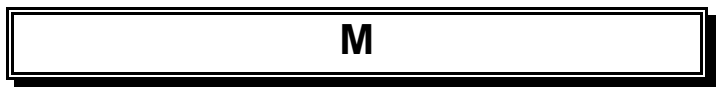

MACHADO NETO, Alfredo José, 64

MARTINO, Vânia de Fátima, 126
MARTINS, Eliana Bolorino

Canteiro, 94

MOREIRA, Gabriela Fernanda, 18

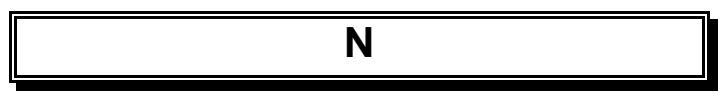

NASCIMENTO, Mari Clair Moro, 81

\section{0}

OLIVEIRA, Anelise Martinelli

Borges, 81

OLIVEIRA, Carla de, 34

OLIVEIRA, Sheila Fernandes

Pimenta e, 46, 64

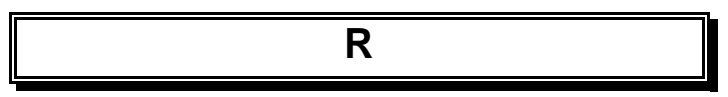

RODRIGUES, Rosilene Maria, 94

\section{$\mathbf{S}$}

SILVA, Deise Aparecida, 34

SOMMERHALDER, Aline, 34, 45

\section{$\mathbf{T}$}

TORRES, Juliana de Oliveira, 126

\section{V}

VAGULA, Edilaine Vagula, 81 

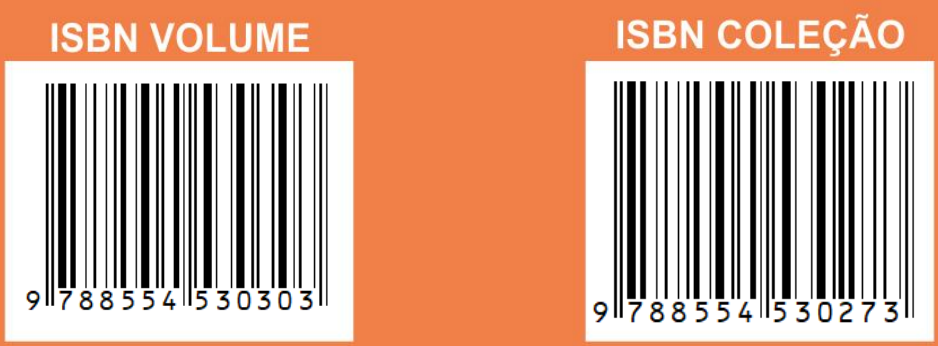

\section{8 | 163713.4688 unifacef.com.br | f}

163706.8700 franca.unesp.br 